\title{
Prof $^{\mathrm{a}}$ Dr $^{\mathrm{a}}$ Catarina Abdalla Gomide \\ Farmacêutica
}

Estudos da qualidade física, química e microbiológica de filés de piracanjuba (Brycon orbignyanus Valenciennes, 1849) submetidos à salga seca e úmida

Tese apresentada à Faculdade de Zootecnia e Engenharia de Alimentos da Universidade de São Paulo, como parte das exigências para a obtenção do título de Livre-Docente da USP

Pirassununga - SP

2005 
Ao Irani,

Lucas,

Carol e Gabi

Dedico ... 


\section{Agradecimentos}

Agradeço a todos que direta ou indiretamente contribuíram para que este trabalho pudesse se concretizar...

À Alba e Terezinha ("Kae") pela dedicação, amizade e incentivo na realização deste projeto.

A meus familiares pela paciência e compreensão...

Aos meus amigos e colegas de Departamento: Marcelo, Estela Moro, Neli e Lia, e da Faculdade de Zootecnia e Engenharia de Alimentos: César, Eliana, Sobral, Mariza, Carlos e Célia, com quem pude contar em todas as horas na vida e no trabalho...

À amiga Elisabete Maria Macedo Viegas pelo auxílio no preparo deste trabalho e na redação final do texto.

Aos alunos de graduação e estagiárias do Laboratório de Bromatologia: Tiara, Tainan, Alice, Lígia, Andréia, Frederico e Rondon que muito colaboraram nas etapas de coleta de dados e análises laboratoriais.

Ao Carlos Eduardo Galan, bolsista do CNPq, que tantas horas dedicou a esse projeto.

Ao Peter Gaberz Kirschnik que auxiliou com dedicação e interesse na implantação do projeto de pesquisa e na condução das análises laboratoriais.

À Alessandra Fernandes Rosa, que com amizade e companheirismo ajudou nos momentos finais de elaboração dessa pesquisa. 
Aos funcionários Apolinário, Rafael, Rosilda, Ana Mônica, Silvana, Royce e Cunha que sempre estiveram presentes em todos os momentos que precisei e, especialmente, à Roseli Sengling Lacerda, com quem compartilhei da dedicação para superar os momentos difíceis da vida profissional.

À funcionária Érica Cristina Mello Ferraz, pela ajuda na elaboração do memorial e preparação dessa tese.

Ao "Caco" pela colaboração no momento da elaboração final deste trabalho.

À Empresa Duke Energy International (Salto Grande/SP) pela doação dos exemplares de piracanjuba.

À Universidade de São Paulo e à Faculdade de Zootecnia e Engenharia de Alimentos pela oportunidade de poder ter realizado essa pesquisa. 


\section{SUMÁRIO}

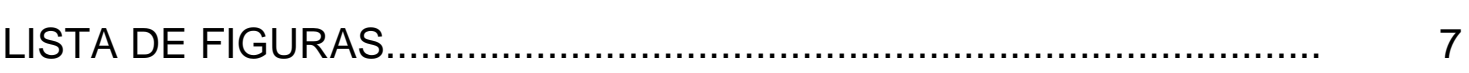

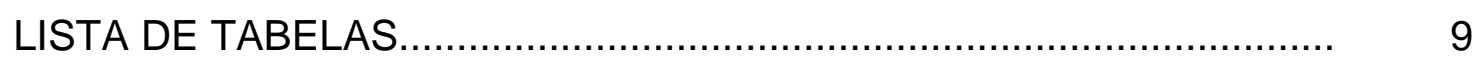

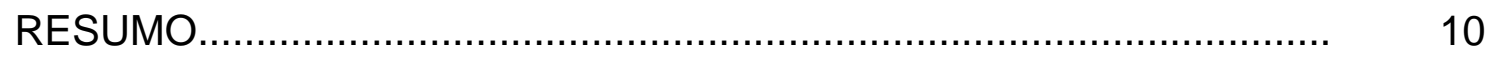

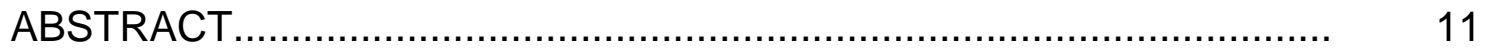

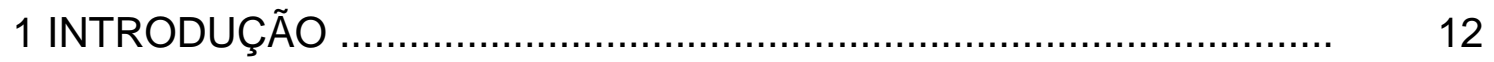

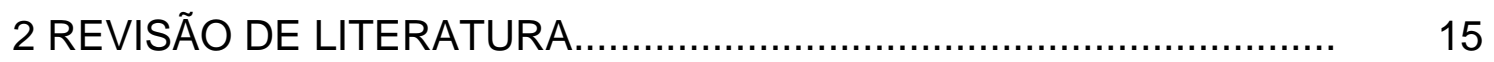

2.1 Considerações sobre a matéria prima - a piracanjuba ...................... 15

2.2 Características da composição corporal do pescado........................ 16

2.3 Conservação dos pescados por meio da salga................................ 20

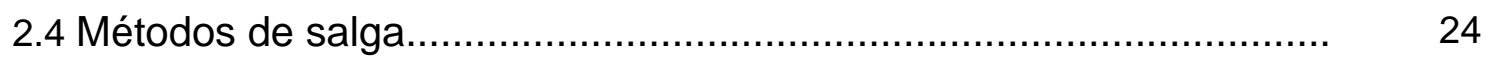

2.5 Principais alterações da qualidade do pescado salgado.................... 27

3 MATERIAL E MÉTODOS.....................................................................

3.1 Local do experimento.............................................................................. 35

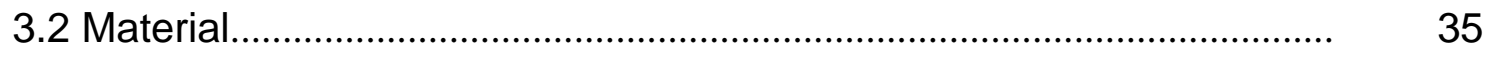

3.3 Métodos........................................................................................... 35

3.3.1 Processamento preliminar.................................................................

3.3.2 Salga em salmoura saturada e salga seca........................................... $\quad 36$

3.3.2.1 Salga em salmoura saturada............................................................ 36

- Preparo da salmoura saturada (30\%)...................................................... 36

- Processo de salga e secagem................................................................... 36

3.3.2.2 Salga seca.................................................................................... 37

3.3.3 Acompanhamento do processo de salga ............................................. 38

3.3.4 Análises químicas, físicas e microbiológicas.......................................... 38

Composição centesimal................................................................................ 39

Cloreto de sódio............................................................................................ 39

Proteína solúvel na salmoura ....................................................................... 40 
Substâncias reativas ao ácido tiobarbitúrico...................................................

Nitrogênio não protéico ............................................................................... 40

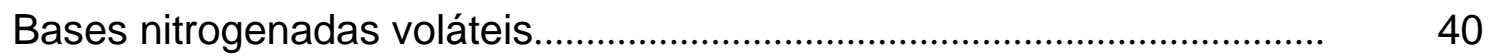

Atividade de água........................................................................................ 40

Calorimetria diferencial de varredura ......................................................... 41

Análises microbiológicas............................................................................

3.3.5 Rendimento do processamento............................................................ 42

3.3.6 Delineamento experimental e análise estatística.................................. 42

4 RESULTADOS E DISCUSSÃO.............................................................

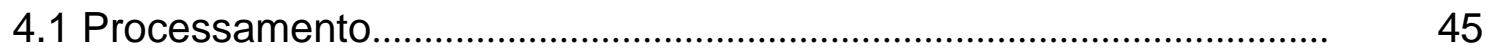

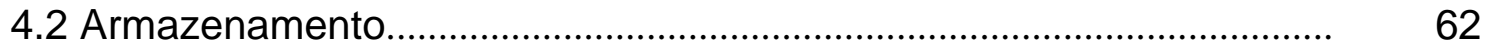

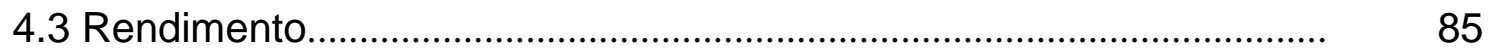

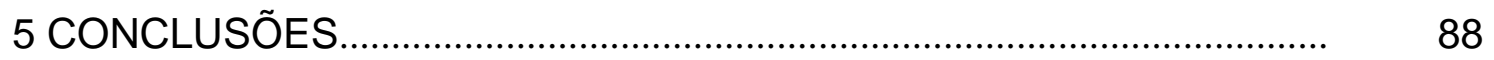

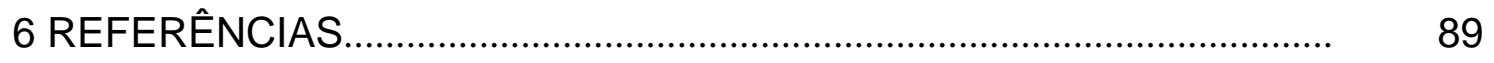




\section{LISTA DE FIGURAS}

Pag.

Figura 1 - Piracanjuba (Brycon orbignyanus) ………....................................... 15

Figura 2 - Filés de piracanjuba submetidos à salga úmida............................. 37

Figura 3 - Filés de piracanjuba submetidos à salga seca................................ 38

Figura 4 - Fluxograma do processamento da salga em piracanjuba (Brycon orbignyanus)

Figura 5 - Valores médios de umidade (\%) e erro padrão dos filés de piracanjuba submetidos à salga seca (SS) e úmida (SU) durante 0 processamento.

Figura 6 - Valores médios de cloreto (\%) e erro padrão dos filés de piracanjuba submetidos à salga seca (SS) e úmida (SU) durante 0 processamento.

Figura 7 - Valores médios de cloreto (\%) e erro padrão dos filés de piracanjuba submetidos à salga úmida e na salmoura durante 0 processamento.

Figura 8 - Valores médios da proteína solúvel $(\mathrm{mg} / \mathrm{mL})$ e erro padrão dos filés de piracanjuba submetidos à salga úmida (SU) durante 0 processamento.

Figura 9 - Termograma de músculo fresco de piracanjuba.

Figura 10 - Termograma de músculo de piracanjuba submetido à salga seca (SS) e úmida (SU) 6 horas após o início do processamento.

Figura 11 - Termograma de músculo de piracanjuba submetido à salga seca (SS) e úmida (SU) 12 horas após o início do processamento.

Figura 12 - Termograma de músculo de piracanjuba submetido à salga seca (SS) e úmida (SU) 168 horas após o início do processamento.

Figura 13 - Valores médios de TBARS (mg de malonaldeído/kg) e erro padrão dos filés de piracanjuba submetidos à salga seca (SS) e úmida (SU) durante o processamento. 
Figura 14 - Valores médios da atividade da água $\left(A_{a}\right)$ e erro padrão dos filés de piracanjuba submetidos à salga seca (SS) e úmida (SU) durante o processamento.

Figura 15 - Filés de piracanjuba submetidos à salga úmida e seca no início do armazenamento (TO)

Figura 16 - Filés de piracanjuba submetidos à salga úmida e seca aos 30 dias de armazenamento.

Figura 17 - Valores médios do teor de sódio $(\mathrm{Na})$ e erro padrão dos filés de piracanjuba submetidos à salga seca (SS) e úmida (SU) durante o armazenamento.

Figura 18 - Valores médios de cloreto (\%) e erro padrão dos filés de piracanjuba submetidos à salga seca (SS) e úmida (SU) durante 0 armazenamento.

Figura 19 - Valores médios de nitrogênio não protéico (NNP) e erro padrão dos filés de piracanjuba submetidos à salga seca (SS) e úmida (SU) durante o armazenamento.

Figura 20 - Valores médios de bases nitrogenadas voláteis (N-BVT) e erro padrão dos filés de piracanjuba submetidos à salga seca (SS) e úmida (SU) durante o armazenamento.

Figura 21 - Valores médios das substâncias reativas ao ácido tiobarbitúrico (TBARS) e erro padrão dos filés de piracanjuba submetidos à salga seca (SS) e úmida (SU) durante o armazenamento... Figura 22 - Valores médios do peso (g) e erro padrão dos filés de piracanjuba para a salga seca (SS) e úmida (SU) durante o

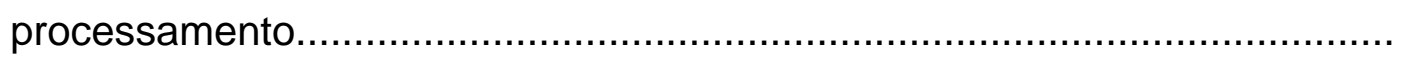




\section{LISTA DE TABELAS}

Pág.

Tabela 1 - Valores médios de umidade (\%), cloreto (\%) e relação cloreto/umidade dos filés de piracanjuba submetidos à salga úmida (SU) e seca (SS) durante o processamento (horas)

Tabela 2 - Valores médios dos resultados da análise por calorimetria diferencial de varredura dos filés de piracanjuba para o peixe fresco e submetidos à salga úmida (SU) e salga seca (SS) durante o processamento (6, 12 e 168 horas).

55

Tabela 3 - Valores médios da composição centesimal (\%) e erro padrão (ep) dos filés de piracanjuba para o peixe fresco e submetidos à salga úmida (SU) e seca (SS) durante o armazenamento.

Tabela 4 - Valores médios dos teores de fósforo e magnésio e erro padrão (ep) dos filés de piracanjuba submetidos à salga úmida e seca durante o armazenamento (dias).

68

Tabela 5 - Valores médios dos teores de cálcio e potássio e erro padrão (ep) para os filés de piracanjuba submetidos à salga úmida e seca durante o armazenamento (dias).

Tabela 6 - Valores médios dos teores de zinco e ferro e erro padrão (ep) para os filés de piracanjuba submetidos à salga úmida e seca durante 0 armazenamento (dias).

Tabela 7 - Valores médios de umidade (\%), cloreto (\%) e relação cloreto/umidade dos filés de piracanjuba submetidos à salga úmida (SU) e seca (SS) durante o armazenamento (dias).....

Tabela 8 - Valores médios da atividade de água $\left(A_{a}\right)$ e análises microbiológicas de filés de piracanjuba submetidos à salga úmida (SU) e

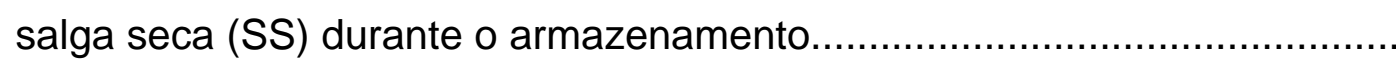
Tabela 9 - Valores médios do peso (g) e rendimento (\%) dos filés de piracanjuba para a salga seca (SS) e úmida (SU) durante o processamento e o armazenamento........................................................... 


\section{Estudos da qualidade física, química e microbiológica de filés de piracanjuba (Brycon orbignyanus Valenciennes, 1849) submetidos à salga seca e úmida}

\section{Resumo}

Esta pesquisa teve como objetivo avaliar algumas características de qualidade da piracanjuba (Brycon orbignyanus Valenciennes, 1849) submetida aos processos de salga seca (SS) e salga em salmoura saturada (ou salga úmida, SU). Foram empregados 36 exemplares de piracanjuba, eviscerados, descamados, descabeçados, com pele, sendo separados 18 para cada tipo de salga. A salmoura (30\%) foi utilizada na proporção de 2:1 (salmoura:filé) e o desenvolvimento da salga foi acompanhado até 168 horas. Após o término da salga, os filés foram colocados em estufa com circulação forçada de ar, por 48 horas, e armazenados à temperatura ambiente por 45 dias. Durante o processamento foram realizadas as análises de umidade, cloreto, calorimetria diferencial de varredura, substâncias reativas ao ácido tiobarbitúrico (TBARS) e atividade de água $\left(A_{a}\right)$ para os filés e para a salmoura, proteína solúvel e cloreto. Durante o armazenamento foram avaliadas as seguintes variáveis: composição centesimal, minerais, cloreto, TBARS, $A_{a}$, bases nitrogenadas voláteis, nitrogênio não protéico e análises microbiológicas (bactérias halofílicas, Clostrídio sulfito redutor, Staphylococcus aureus, Salmonella sp, Coliformes totais e Coliformes fecais). Os rendimentos do processamento e armazenamento também foram quantificados. O delineamento experimental foi o inteiramente casualizado com dois tratamentos e três repetições por tratamento, para os períodos de processamento e armazenamento. A atividade de água foi reduzida durante o processamento e armazenamento, prevenindo o desenvolvimento de microrganismos em ambas as salgas. Houve diminuição da estabilidade térmica das proteínas miofibrilares, com a adição de sal no músculo da piracanjuba, provocando redução das temperaturas de desnaturação da miosina e da actina, para ambas as salgas, sendo que a salga seca apresentou uma ação deletéria maior que a úmida. Os filés de piracanjuba salgados e secos apresentaram, para a salga úmida, rendimento superior ao da seca, após 168 horas de salga, porém ao final do período de armazenamento, os dois tratamentos tiveram rendimentos bem semelhantes. Os processos de salga empregados nos filés de piracanjuba geraram produtos de características diferentes, porém as alterações observadas não influíram na estabilidade do produto final, que foi considerado próprio para o consumo.

Palavras-chave: análise calorimétrica diferencial, bactérias halofílicas, rendimento, sal, pescado 


\title{
Studies of physical, chemical and microbiological qualities of piracanjuba (Brycon orbignyanus Valenciennes, 1849) fillets submitted to dry and moisture salting.
}

\begin{abstract}
The objective of this study was to evaluate some quality characteristics of piracanjuba (Brycon orbignyanus Valenciennes, 1849) when submitted to saturated brine and dry salting processes Thirty six piracanjuba were eviscerated, scaled, and beheaded; fillets with skin were obtained and 18 set apart for each type of salting. Brine (30\%) were utilized in 2:1 ratio (salting: fillet) and the salting process was followed until 168 hours. After the salting the fillets were dried in convection oven by 48 hours and stored in environment temperature by 45 days. During the process analysis were carried out to moisture, chloride, differential scanning calorimeter, thiobarbituric acid reactive substances (TBARS), Activity of water (Aw) to fillets and soluble protein and chloride in brine. The variables observed during the storage were: proximate composition, minerals, chloride, TBARS, Aw, total volatile bases nitrogen, non-protein nitrogen, and microbiological analysis (halophilic bacteria, Clostrídio sulfito redutor, Staphylococcus aureus, Salmonella $\mathrm{sp}$, total and fecal coliform).Storage and processing yield were analyzed. The experimental design was entirely randomized with two treatments and three repetitions. The water activity was reduced during the process and the storage, preventing the microorganism developing in both salting. There was a reduction of myofibril protein thermal stability wit the addition of salt in the piracanjuba muscle, reducing the myosin and actin temperature denaturation, for both salting. The dry salting showed a deleterious action greater than the wet salting. For the wet salting the piracanjuba fillets showed a yielding greater than the dry salting after 168 hours. However, at the end of the storage period, both treatments showed a quite similar yielding. The salting process was carried out in the piracanjuba fillets resulted in products with different characteristics, but it doesn't observed alterations that influenced in the stability of final products. Concluding this product was evaluated properly fitted to be consumed.
\end{abstract}

Key words: differential scanning calorimetry, fish, halophilic bacteria, salt, yield. 


\section{INTRODUÇÃO}

Grande parte da superfície do nosso planeta está recoberta por água, onde vivem ao redor de 20.000 espécies animais. Desde os tempos remotos, o consumo do pescado e de outros alimentos obtidos do mar tem um importante papel nas regiões costeiras e para as populações que dependem dela para viver.

A produção mundial da pesca de captura e da aqüicultura forneceu 101 milhões de toneladas de pescado para o consumo humano, em 2002, o que equivale a um fornecimento de $16,2 \mathrm{~kg} /$ per capita. A produção da aqüicultura cresceu de $3,9 \%$ da produção total, em 1970, para 29,9\%, em 2002, crescimento este considerado o mais rápido que qualquer outro setor de produção de alimentos de origem animal. O Brasil está entre os dez primeiros países em termos de captura continental de pescados no mundo, correspondendo a 2,5\% da produção mundial (218 milhões de toneladas), segundo dados da FAO (2002).

A produção de pescados no Brasil, na década de 80 , era de, aproximadamente, 750 mil toneladas anuais compostas principalmente por peixes marinhos (OGAWA \& MAIA, 1999). A aqüicultura é atualmente uma atividade muito promissora e que tem sido bastante incentivada, especialmente após a criação da Secretaria Especial de Aqüicultura e Pesca (SEAP), em 2003. A expectativa de crescimento da produção poderia ocorrer com o cultivo planejado de peixes de água doce, pois as maiores bacias hidrográficas do mundo estão localizadas em território brasileiro, perfazendo um total de $4.000 \mathrm{~km}$ de extensão em ambientes de águas interiores.

O pescado pode ser comercializado nas formas "in natura" ou industrializado, sendo que o processo de industrialização compreende, de alguma maneira, o manuseio e a preservação, como por exemplo: preparo de filés e outras partes comestíveis do pescado, pescado salgado, defumado, embutido de pescado, pasta de pescado, farinha de peixe, óleo de pescado, dentre outros (OGAWA \& MAIA, 1999).

Apesar do Brasil ser um dos maiores consumidores de pescado salgado, a indústria brasileira não conseguiu se desenvolver adequadamente de modo a acompanhar seu processamento. Cerca de $29 \%$ dos pescados capturados são 
utilizados no processo de salga, sendo a região Nordeste a principal região consumidora de pescados salgados no país. No entanto, as técnicas de salga e secagem são rudimentares, resultando em um produto de qualidade inferior (TAVARES, 1995).

Com relação à nutrição há necessidade de uma busca contínua do aumento de oferta de suprimentos protéicos, principalmente quando se trata de produtos de origem animal como o pescado, cuja possibilidade de uma participação mais eficaz no mercado depende, entre outras coisas do desenvolvimento de novas técnicas de industrialização. O valor nutritivo e os preços dos peixes dependem da textura da carne, da composição química, do rendimento e de fatores relacionados aos métodos de captura e beneficiamento. A industrialização do pescado permite aumentar a diversidade de produtos para a comercialização, o controle de qualidade e o aproveitamento de resíduos.

Nos países em desenvolvimento o pescado e, em particular, os peixes são a maior fonte de proteína animal de alto valor biológico, com um excelente balanceamento de aminoácidos essenciais, rico em minerais e em ácidos graxos polinsaturados, especialmente ômega 3 e ômega 6 (CONTRERAS-GUZMÁN, 2002).

O conhecimento da composição química dos pescados é de fundamental importância para a padronização dos produtos alimentares na base de critérios nutricionais, pois fornece subsídios para decisões de caráter dietário, acompanhamento de processos industriais e seleção de equipamentos para otimização econômica-tecnológica (CONTRERAS-GUZMÁN, 1994).

Os atributos da qualidade para o pescado envolve os aspectos físicos, químicos, microbiológicos e sensoriais e devem ser avaliados e compreendidos não somente durante a conservação "in natura", bem como no desenvolvimento dos processos para a obtenção de produtos de qualidade.

Neste sentido, este estudo se propôs avaliar o processamento de filés de piracanjuba (Brycon orbignyanus Valenciennes, 1849) submetidos a dois métodos de salga. Análises físicas, químicas e microbiológicas foram realizadas desde a matéria prima até o produto final, filés salgados e secos, com o objetivo de 
acompanhar as alterações de qualidade que ocorreram na carne durante o processamento e o armazenamento. 


\section{REVISÃO DE LITERATURA}

\subsection{Considerações sobre a matéria prima - a piracanjuba}

A piracanjuba (Brycon orbignyanus Valenciennes, 1849), pertence à classe Osteichthyes, família Characidae e subfamília Bryconinae (CASTAGNOLLI, 1992). É uma espécie de peixe de água doce, nativa do Brasil e com excelente potencial para aqüicultura (Figura 1). Podemos descrevê-la como um peixe de escamas, corpo fusiforme, de coloração prateada com reflexos esverdeados e nadadeiras vermelhas, podendo alcançar até $1 \mathrm{~m}$ de comprimento total e $5 \mathrm{~kg}$ de peso. Vive tanto no canal dos rios quanto nas áreas próximas às margens e em locais de corredeiras. A coloração da carne de piracanjuba é laranja-avermelhado devido à deposição dos pigmentos carotenóides provenientes de alimento natural. Os pigmentos conferem um aspecto agradável e um melhor valor comercial (SANTAMARIA \& ANTUNES, 1998/1999).

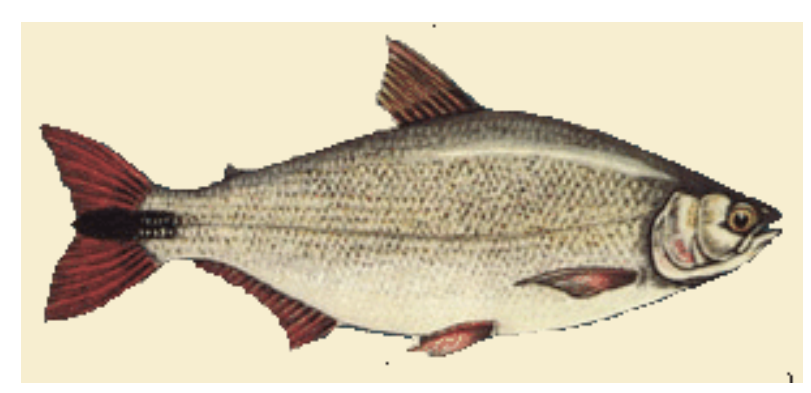

Figura 1 - Piracanjuba (Brycon orbignyanus)

Sua origem é da Bacia do Paraná-Uruguai, integrada pelos rios: Prata, Paraná e Uruguai, porém devido à intensa degradação ambiental, a piracanjuba teve sua população drasticamente reduzida (AZEVEDO, 1972). Em algumas áreas, a captura dessa espécie está cada dia mais difícil e ela está ameaçada de extinção (OLIVEIRA et al., 2004).

Segundo CASTAGNOLLI (1992), a piracanjuba e o matrinchã, representantes do gênero Brycon, da subfamília Bryconinae, fazem parte das espécies nativas que apresentam enorme potencial para a criação comercial. 
Assim, os briconídeos são peixes de piracema (reofílicos) muito dependentes de alimentos alóctones (frutos e sementes). Porém, foram muito prejudicados pela construção de barragens nos rios e desmatamento da vegetação ciliar. As grandes barragens constituem barreira intransponível, na rota migratória dos peixes de piracema, que são os mais valiosos do ponto de vista da pesca, reduzindo ou eliminando sua eficiência reprodutiva (BEDORE, 1999).

Os briconídeos têm despertado grande interesse pelas instituições de pesquisa nos últimos anos, tanto pela excelente qualidade da carne, quanto pelo hábito alimentar no ambiente natural, que é composto, principalmente, por frutos e sementes. A partir de 1992 a Companhia Energética de Minas Gerais (CEMIG), adquiriu exemplares de piracanjuba com o intuito de desenvolver pesquisa com esta espécie visando melhor compreender sua reprodução em cativeiro (DUMONT-NETO et al., 1997). De acordo com VASQUES (1997), o rápido crescimento e o ganho de peso demonstrado em criações experimentais, são indicadores para a seleção dessa espécie como alternativa para o desenvolvimento da piscicultura nas regiões Norte, Centro-Oeste, Sudeste, Nordeste e Sul do Brasil.

Segundo CONTE (1995), o desenvolvimento da piscicultura com espécies nativas é de grande interesse para a conservação da biodiversidade e se constitui uma prioridade do IBAMA. A partir de 1990, vários grupos de pesquisa têm-se direcionado à viabilização dos Brycon na piscicultura, e também no repovoamento de reservatórios hidrelétricos (OLIVEIRA et al., 2004).

\subsection{Características da composição corporal do pescado}

O pescado é uma das principais fontes de proteína para o ser humano. Apresenta algumas características que o torna muito suscetível à deterioração, tais como elevada atividade de água, composição química, teor de gorduras insaturadas de fácil oxidação e $\mathrm{pH}$ próximo à neutralidade (FRANCO \& LANDGRAF, 2003). 
Com relação aos principais componentes, a carne dos pescados é semelhante à carne de outros animais como bovinos, suínos e aves. Porém, pelo fato de viverem na água são observadas algumas diferenças específicas. Pode-se encontrar no músculo dos peixes valores médios de 60 a $85 \%$ para a umidade, de 15 a 23\% para a proteína, de 0,6 a 36\% para os lipídeos, de 1 a 2\% de cinzas e 0,3 a $1 \%$ de carboidratos (OGAWA \& MAIA, 1999).

A composição química do pescado apresenta variações em função da época do ano, espécie, idade, sexo e das condições de alimentação. Em geral, há uma relação inversa entre os teores de umidade e lipídeos, bem como entre água e proteína. Se o pescado for rico em lipídeos, a umidade é baixa, porém a soma destes dois componentes será ao redor de $80 \%$. A umidade varia entre as diversas partes do pescado, sendo maior nos de carne vermelha (CONTRERASGUZMÁN, 2002).

Em função das características das espécies, os peixes podem ser classificados em pescado magro e gordo. Nos pescados magros, o teor de água é praticamente invariável durante o ano todo, situando-se ao redor dos 80\%. Para o pescado gordo, o teor de água é bastante variável e dependendo da época do ano, apresenta valores de 60 a 75\%. Segundo STANBY (1965), os pescados podem apresentar teores de lipídeos variando entre 5 e $15 \%$, sendo os peixes gordos aqueles com mais de $15 \%$ de gordura. Nos peixes magros o teor de gordura é relativamente constante, cerca de $2 \%$.

As bases nitrogenadas voláteis (BNV), também denominadas de bases voláteis totais (BVT), compreendem os compostos como amônia, trimetilamina, dimetilamina, etc. A base volátil mais representativa no início do processo de degradação é a amônia, originária dos produtos de desaminação dos derivados do ATP. Posteriormente, a amônia proveniente da degradação de outros compostos nitrogenados, juntamente com a trimetilamina, formada a partir do óxido de trimetilamina (OTMA), tornam-se presentes. Os pescados de água doce não apresentam esse composto.

A análise de nitrogênio volátil já era usada no século passado para se avaliar a decomposição dos pescados (FARBER, 1965) e, apesar de pequenas 
modificações, permaneceu até hoje devido à sua simplicidade analítica e razoável concordância com o estado de frescor. O teor de BNV atinge de 5 a $10 \mathrm{mg} / 100 \mathrm{~g}$ de carne, para peixes em excelente estado de frescor; de 15 a $25 \mathrm{mg} / 100 \mathrm{~g}$ de carne, para peixes com frescor razoável; de 30 a $40 \mathrm{mg} / 100 \mathrm{~g}$ de carne, para peixes que estejam no início da putrefação e, teores acima de $50 \mathrm{mg} / 100 \mathrm{~g}$ quando apresentarem estado de deterioração avançado (OGAWA \& MAIA, 1999).

Os teores dos compostos nitrogenados (TMA, DMA, amônia) resultantes da deterioração do pescado fresco ou processado são expressos pelo teor de bases voláteis totais. No Brasil, o limite legal para BVT em pescado fresco e em produtos de pescado, como por exemplo o curado, é de $30 \mathrm{mg}$ de nitrogênio por $100 \mathrm{~g}$ de carne (BRASIL, 1997). Porém, na literatura há relatos de valores de até 200 mg/100 g, para o pescado salgado, prensado e seco, que possui uma qualidade aceitável. Por isso, muito embora seja discutível o estabelecimento de limites superiores de BVT para avaliar o grau de frescor de pescado, o teor de BVT tem sido amplamente utilizado na avaliação de sua qualidade.

As BVTs têm aplicação principalmente para estabelecer o limite de frescor para a matéria-prima ser utilizada no processamento. Na Argentina (LUPIN \& TRUCCO, 1978), o mesmo valor de $30 \mathrm{mgN} / 100 \mathrm{~g}$ é utilizado como limite aceitável para pescado em conservas, salgados ou secos. CONNEL (1975) cita valores limites de $30 \mathrm{mgN} / 100 \mathrm{~g}$ para atum e peixe-espada congelados e 100-200 $\mathrm{mgN} / 100 \mathrm{~g}$ para peixe salgado seco.

BERAQUET et al. (1983), comparando os processos de salga úmida e salga mista para cavalinha (Scomber japonicus), observaram que os teores de BVT no primeiro processo situavam-se entre $12-15 \mathrm{mgN} / 100 \mathrm{~g}$ de amostra e na salga mista entre 25-35 mgN/100g de amostra. Demonstraram ainda que há intensa lixiviação dessas bases no músculo para salmoura circundando o pescado, uma vez que há grande evolução de BVT nas salmouras, ao longo do processo da salga, particularmente no caso da salga mista onde, após 15 dias de salga, o teor de BVT atingia $55 \mathrm{mgN} / 100 \mathrm{~g}$ de salmoura.

O método clássico para BNV, em pescados, consiste na destilação direta do músculo triturado ou de extratos aquosos do músculo. As diversas 
combinações que têm sido usadas apresentam como agentes extratantes: água destilada, ácido tricloroacético $5 \%$, ácido sulfúrico $10 \%$ ou etanol p.a. e, como compostos alcalinos para deslocamento do nitrogênio: óxido de magnésio, hidróxido de sódio, borato de sódio e carbonato de sódio.

Embora a determinação do nitrogênio não protéico (NNP) seja bastante questionada como índice de frescor em pescados, ela ainda continua sendo empregada. O NNP é a primeira fração a ser afetada pelo crescimento dos microrganismos que poderão utilizá-lo como fonte de energia ou produzir maior quantidade de NNP através de suas proteases secretadas no músculo.

A tilápia nilótica apresentou valores de 294 mg NNP \% logo após a morte. Durante o armazenamento (20 dias no gelo) o teor de NNP diminuiu, atingindo 208 mg NNP \% (NETTO, 1984). Resultado próximo foi obtido, para esse mesmo peixe, sendo de $344 \mathrm{mg}$ NNP \%, logo após a morte e de 258 mg NNP \% em 16 dias (CONTRERAS-GUZMÁN, 1994). Segundo esse último autor, o comportamento do NNP depende da espécie, isto é, de sua capacidade de autólise, ou por possuir um potencial proteolítico endógeno alto, ou devido às próprias características anatômicas.

Os minerais encontrados na maioria dos pescados são estáveis e variam de 1 a $2 \%$ do total da composição química. Os animais aquáticos são influenciados sensivelmente quali e quantitativamente por eletrólitos. A maioria desses organismos controla sua pressão osmótica através de sais inorgânicos (OGAWA \& MAIA, 1999). Segundo CONTRERAS-GUZMÁN (1994) os valores de cinzas para os peixes de água doce apresentam flutuações maiores que vão de 0,98 a 3,29\%. Muitas vezes, devido à inclusão de ossos no preparo do filé, esses valores podem ser maiores.

Nos peixes, normalmente ocorrem variações nos conteúdos de $\mathrm{Na}$, Ca e Fe entre espécies, enquanto que $\mathrm{P}$ e $\mathrm{K}$ mostram menos variações. $\mathrm{O}$ mineral $\mathrm{Na}$ encontra-se em maior concentração no sangue do que no músculo, sendo que ocorre o inverso para o K. Quanto ao $\mathrm{Cu}$ e $\mathrm{Fe}$, estes são importantes como componentes de pigmentos protéicos respiratórios, como a hemoglobina, mioglobina, hemocianina, etc. Os peixes de carne vermelha apresentam alto teor 
de Fe, devido ao conteúdo em hemoproteína. Em geral, ao comparar-se a carne bovina com a de pescado, encontramos valores maiores para Na e Ca (OGAWA \& MAIA,1999).

Os minerais presentes nos pescados não são absorvidos totalmente pelo nosso organismo, que poderia ser influenciado por fatores tais como forma iônica, substâncias interferentes, dentre outros. Por exemplo, o Fe em peixes é de absorção mais fácil do que de alimentos vegetais, devido à sua forma de apresentação (Fe-hemo) (OGAWA \& MAIA, 1999).

Em um estudo realizado com filés de peixes de água doce: pacu, matrinxã, carpa, tilápia, curimbatá, tambaqui e bagre africano, pôde-se observar que os teores de P variaram de 2.107 a 1.723 mg/kg; os valores de $\mathrm{K}$, de 3.063 a 207 mg/kg; para o Ca, teores de 568 a 94,1 mg/kg; para o Na, de 666 a 222 mg/kg; para o Mg, de 272 a $190 \mathrm{mg} / \mathrm{kg}$; os teores de Fe, de 13,9 a 3,8 mg/kg e para o Zn, de 11,7 a $2,8 \mathrm{mg} / \mathrm{kg}$, sendo todos expressos em base úmida (MANTOVANI \& MORGANO, 1995).

\subsection{Conservação de pescados por meio de salga}

A conservação pelo sal é um dos mais antigos processos utilizados na preservação dos alimentos. O cloreto de sódio foi e é bastante empregado na conservação de carnes, sendo o ingrediente essencial na sua maturação. Neste processo devido à adição dos agentes de cura ocorrem modificações na carne que afetam sua concentração, cor, aroma, sabor e textura (GAVA, 1984). Além de

conferir sabor ao produto, protege o alimento contra a deterioração microbiológica pelo controle da atividade de água (OOIZUMI et al., 2003).

Os povos primitivos verificaram que além da carne de diferentes animais, outros produtos como as hortaliças e pescados podiam ser preservados por meio de imersão em salmouras ou pelo tratamento com sal por via seca, seguido ou não de desidratação ao sol (LEITÃO, 1995).

A utilização da salga como forma de preservar pescados remonta a 3.500 ou 4.000 anos a.C., atingindo seu auge nos séculos 18 e 19, mas com o advento 
de outros métodos de conservação, houve uma considerável redução no volume dos pescados salgados (SHENDERYUK \& BYKOWSKI, 1994). Atualmente, cerca de $8,2 \%$ das capturas mundiais de peixe estão sendo preservadas por métodos tradicionais de cura como a salga, secagem e defumação (SANNAVEERAPPA et al., 2004).

Muitos estudos têm sido desenvolvidos com o intuito de se esclarecer os mecanismos que envolvem o processo de salga, especialmente nos pescados (MACHADO, 1984; LEITÃO, 1995; WANG et al., 2000) e apesar de ser uma técnica simples, pode levar à perda de grande quantidade do produto salgado por motivos como secagem deficiente, quantidade insuficiente de sal, embalagem inadequada, dentre outros (LESSI, 1995).

O sal empregado na salga do pescado é o sal comum ( $\mathrm{NaCl})$, que pode ser obtido de diferentes fontes, ter nível de impurezas e granulometrias variados. No entanto, para obtenção de produtos de qualidade deve ser realizado com um sal apresentando nível elevado de pureza. Muitas impurezas presentes no sal como ferro, cobre e cálcio, podem causar alterações no produto, tais como descolorações, alterações na textura do produto final, catalisar reações de oxidação, contaminação por microrganismos, etc (MACHADO, 1994). A presença de íons de cálcio e magnésio retarda o transporte de cloreto de sódio até o músculo (SHENDERYUK \& BYKOWSKI, 1994).

O processo de salga está baseado no princípio da desidratação osmótica. A entrada de sal no interior das células aumenta a pressão osmótica, provocando a saída de água dos tecidos, diminuindo a atividade de água no músculo e, conseqüentemente, limitando o crescimento de microrganismos (FERREIRA \& OETTERER, 1992). Outro fator está, contudo, aparentemente envolvido: o próprio sal, em concentrações acima de $6 \%$, reduz ou previne a atividade de bactérias (BURGESS et al., 1967).

Entretanto, outros fatores podem ter efeito sobre a remoção de água e a penetração do sal e, dentre eles: a espessura do músculo ou o tamanho do peixe, o teor de gordura do pescado, a temperatura, a pureza química do sal e a pré- 
elaboração do pescado (BURGESS et al., 1967; SHENDERYUK \& BYLOWSKI, 1994; LEITÃO, 1995).

Durante o processo de salga, os íons de sódio e cloro são transportados da salmoura para o interior do pescado e a água deste, para a salmoura. O transporte ocorre em intensidades diferentes durante a salga, sendo a concentração de cloreto de sódio, existente no tecido muscular do pescado e na salmoura, o fator mais importante, como determinante da intensidade do transporte das substâncias participantes do processo (SHENDERYUK \& BYLOWSKI, 1994).

Segundo MACHADO (1984), o sal atua na conservação do pescado, de três formas: como agente desidratante, por meio de seu poder de absorção de água interna dos tecidos dos peixes; como bactericida, agindo sobre os microrganismos proteolíticos, e acelerando a ação das enzimas existentes na carne pescado.

Nos tecidos animais em solução de cloreto de sódio $(\mathrm{NaCl})$, os íons se fixam nas regiões das moléculas protéicas que contém cargas elétricas. Nas proteínas, os principais contribuintes são os grupos $\mathrm{NH}_{2}$ da lisina, e o $\mathrm{COOH}$ do ácido glutâmico e do ácido aspártico. Em salmoura diluída (por exemplo, 7\%), as proteínas têm grupos suficientes para ligar todos os íons cloreto, os quais atraem e fixam a água (salting in). Como conseqüência, os peixes ou os filés terão um aumento de peso e de volume, pela maior hidratação e pequena penetração de sal (DEL VALLE \& NICKERSON, 1967a; SGARBIERI, 1996). Entretanto em elevadas concentrações salinas, as proteínas não têm capacidade para ligar todos os íons cloreto, os quais permanecem em solução. Desta forma, competem com a proteína pela água do sistema, ocasionando perda de água de hidratação pelas moléculas protéicas, atração mútua e formação de precipitado (salting out), devido à desidratação (DEL VALLE \& NICKERSON, 1967a; SGARBIERI, 1996). Geralmente, este fenômeno ocorre quando a concentração de $\mathrm{NaCl}$ na salmoura, está entre 15 e 17\% e no músculo acima de 8\% (BURGESS et al., 1967).

DEL VALLE \& NICKERSON (1967a, b) estudaram os mecanismos básicos envolvidos nos processos de salga e secagem do peixe espadarte (Xiphias gladius). No primeiro trabalho, DEL VALLE \& NICKERSON (1967a) teceram considerações sobre o equilíbrio da salga de peixes, em várias concentrações de 
salmoura realizadas em três temperaturas de salga. Duas variáveis foram selecionadas para descrever o equilíbrio da salga entre o músculo e a salmoura: a) a concentração de sal no músculo, e b) o coeficiente de distribuição de sal entre o músculo e a salmoura (obtido através do quociente entre a concentração de sal no músculo e a concentração de sal na salmoura). Os autores relataram que a concentração de sal no músculo aumentou continuamente com a concentração da salmoura e o coeficiente de distribuição aumentou no início, alcançou um valor máximo e diminuindo a seguir, sempre com o aumento da concentração da salmoura. Pequenas diferenças foram observadas entre as variáveis de equilíbrio da salga, quando o processo ocorria a $5^{\circ} \mathrm{C}$ ou a $25^{\circ} \mathrm{C}$, mas a $37^{\circ} \mathrm{C}$, todas as variáveis estudadas foram relativamente mais baixas.

No trabalho subseqüente, DEL VALLE \& NICKERSON (1967b) avaliaram os aspectos da dinâmica da migração dos íons de sódio e cloreto para, e dentro do músculo do peixe (Xiphias gladius) do ponto de vista da difusão e condução eletroquímica em várias concentrações de salmoura e em duas temperaturas. Os autores observaram que o coeficiente de difusão do sal depende da concentração de sal no músculo e da temperatura no meio. No início, o coeficiente de difusão diminuiu, em seguida atingiu um valor mínimo, e então aumentou com o aumento da concentração de sal. As variações foram mais acentuadas a $25^{\circ} \mathrm{C}$ do que a $5^{\circ} \mathrm{C}$.

WANG et al. (2000) estudaram a difusibilidade do sal em músculos de salmão do Atlântico nos estados de pré-rigor, rigor-mortis pleno e pós-rigor, utilizando um modelo matemático. Foi verificado que o músculo de salmão, em estado de pré-rigor, apresentava a concentração mais baixa de sal quando comparado aos outros estados.

O cloreto de sódio possui propriedades bactericidas principalmente em altas concentrações, porém algumas bactérias crescem em meio contendo de 20 a 30 $\%$ de sal (LEITÃO, 1995). Segundo OGAWA \& MAIA (1999), no processo da salga ocorre ainda uma redução no desenvolvimento de microrganismos aeróbicos, devido à diminuição da solubilidade do oxigênio na salmoura, ou pela desinfecção direta do produto com íons cloreto. 
A salga e a secagem dos pescados produzem perda de quantidades significativas de proteínas, peptídeos e aminoácidos e estas perdas são maiores durante a salga úmida do que a salga seca (SANNAVEERAPPA et al., 2004).

Com relação ao rendimento dos processos de salga, OGAWA \& MAIA (1999) relata que o rendimento da salga seca é mais baixo que o da úmida. ZAPATA et al. (1986) obtiveram como rendimento de processo, aproximadamente, $18 \mathrm{~g}$ de polpa de peixe salgado seco para cada $100 \mathrm{~g}$ de peixe, sendo que a fração protéica manteve-se quase que inalterada, com perdas inferiores a 4\%. Durante a estocagem de 90 dias, o produto mostrou estabilidade na sua composição centesimal.

\subsection{Métodos de salga}

O processo de preservação de pescados por meio da salga tem sofrido modificações ao longo do tempo. Além dos processos tradicionais - salga seca ou salga em salmoura saturada - novos procedimentos como salga por injeção de salmoura têm sido empregados como forma de melhorar a qualidade dos produtos finais. Ainda, produtos "levemente" salgados, tem tido uma boa aceitação na Europa em substituição aos fortemente salgados. Este processo aumenta a capacidade de retenção de água e rendimento do músculo do peixe (THORARINSDOTTIR et al., 2002).

O tradicional processo da salga pode ser realizado através de dois métodos básicos: o seco e o úmido. No Brasil, a salga úmida é separada em dois procedimentos: a salga em salmoura ("pickling") e a salga mista (LESSI, 1995).

O método da salga seca consiste em impregnar o pescado com sal seco. A formação de pilhas, em camadas intercaladas de sal e pescado, garante que toda a superfície do peixe fique em contato com sal. A água que gradualmente vai sendo perdida pelo músculo deve ser drenada de maneira que a pilha permaneça exposta ao ar atmosférico. Este tipo de salga é o mais utilizado para espécies de peixes de grande porte e pouco gordurosos como o bacalhau, pirarucu e cações. Em geral, utiliza-se 30 a 40\% de sal, devendo as camadas superior e inferior da pilha serem formadas por uma grossa capa de sal, para que haja uma maior 
proteção contra o contato com o ar (MACHADO, 1984). A salga seca apresenta a vantagem de favorecer maior desidratação do peixe sendo mais adequada para obtenção do pescado desidratado (seco ou defumado). No entanto, pode ocorrer com freqüência o fenômeno oil burnt (queimadura com cor amarelada, devido à oxidação de lipídios) pelo contato do oxigênio do ar com o produto (OGAWA \& MAIA, 1999).

No processo da salga úmida, o pescado é imerso em salmoura a uma certa concentração (variável em função do objetivo do processamento), garantindo-se a ausência de oxigênio no meio e, assim, protegendo a gordura do processo de oxidação (LESSI, 1995; OGAWA \& MAIA, 1999). É aconselhável a agitação do pescado durante este processo. Esta técnica é apropriada para a salga de espécies de peixes gordurosos, como a sardinha e a maioria das espécies de água doce (MACHADO, 1984).

Pelo método intermediário, a salga mista, os peixes são colocados entre camadas de sal até o alto do recipiente, que deverá receber uma tampa com um peso colocado sobre ela, para prensar os peixes e garantir que a água exsudada forme a salmoura necessária para cobrir todos os peixes (LESSI, 1995). Esse processo é empregado com freqüência para salga da sardinha, da manjuba e espécies magras como o cação, propiciando um certo grau de proteção contra a oxidação lipídica (MACHADO, 1984).

Segundo OGAWA \& MAIA (1999) outros métodos de salga como a salga por prensagem e salga rápida podem ser empregados. A salga por prensagem é realizada após aplicação da salga mista, sendo que o produto é em seguida empilhado e prensado mecanicamente. Obtém-se um produto de menor teor de sal que nos anteriores. A salga rápida possui três métodos, a saber: no primeiro a matéria prima é colocada em um recipiente no qual a pressão interna vai sendo reduzida, seguida de injeção por salmoura; no segundo, é empregado um injetor de grosso calibre para injetar salmoura em determinadas áreas do músculo, e no terceiro, após a salga úmida, faz-se uma prensagem e o produto final é denominado salgado e prensado. Este último tipo de processo é bastante aplicado no Brasil para sardinha. 
Em geral, após o término do processo da salga, que varia de três a quinze dias, os pescados são submetidos a processos básicos de secagem, com a finalidade de diminuir a umidade $e$, conseqüentemente, proporcionar maior estabilidade ao produto. A secagem, dos produtos salgados pode ser efetuada através do método natural, utilizando-se a ação do sol e do vento. No entanto, a qualidade e a padronização do produto final só é alcançada com o uso de equipamentos, nos quais as condições dos processos podem ser controladas (MACHADO, 1984). Também secadores solares têm sido propostos como alternativas convenientes para secagem de peixes e seus produtos (ISMAIL, 1983).

O pescado salgado, salgado prensado e salgado prensado-seco são produtos que fazem parte de um grupo de alimentos, conhecidos como aqueles de teor intermediário de umidade, definido por LABUZA et al. (1972) como alimentos com atividade de água $\left(A_{a}\right)$ entre 0,60 e 0,85. Segundo SANCHES \& JAM (1965) para um pescado salgado, a secagem pode ser considerada ótima quando a umidade se encontra na faixa de $35 \%$ a $40 \%$. NORT (1974) sugere que o teor de umidade não deve ser superior a $40 \%$ enquanto que o teor de sal, na forma de cloreto de sódio, permanecer na faixa de 20 a $25 \%$.

MATSUNAGA (1996) propõe um processo de salga para climas tropicais, os quais podem ser armazenados à temperatura ambientes durante longos períodos de tempo. O processo consiste basicamente, no pré-preparo do peixe, imersão em salmoura saturada durante dois a nove dias até que o músculo atinja 13 ou $14 \%$ de cloreto de sódio. O pescado estaria neste momento, pronto para comercialização, sem necessidade de secagem prévia. Se houver necessidade de prolongar a vida de prateleira do produto, o mesmo deveria ser submetido a uma segunda salga em salmoura saturada, podendo alcançar no músculo a concentração de 17 a 20\% de cloreto de sódio.

MENDELSOHN (1974) faz uma revisão das técnicas de salga rápida de pescado, apontando e discutindo as vantagens e desvantagens de cada tipo. $\mathrm{O}$ autor cita o método de DEL VALLE \& NICKERSON (1968), no qual o filé de peixe sem pele é moído e simultaneamente misturado com sal (20 a 100\% do peso). A 
mistura é então bem homogeneizada, prensada para retirada de água e em seguida o bloco de peixe obtido é submetido a secagem. O processo é indicado para ser aplicado em países em desenvolvimento, pelo seu baixo custo e pela possibilidade de utilização de peixes de baixa aceitação ou de subprodutos da industria de filtragem.

ZAPATA et al. (1986) aplicaram a técnica da salga rápida em músculo moído de tilápia do Nilo, obtendo-se blocos de polpa de peixe salgado. Estes foram submetidos à secagem ao sol por 20 horas ou em estufa com circulação de ar a $38^{\circ} \mathrm{C}$ por 50 horas. Os blocos de peixes secos ao sol e em estufa continham $46,7 \%$ e $44,5 \%$ de umidade, 24,8 e $26,1 \%$ de proteína, 1,4 e $1,7 \%$ de lipídios e 23,0 e 24,7\% de cloreto de sódio, respectivamente.

A composição química e o peso do pescado salgado experimentaram considerável mudança durante o processo de salga e armazenamento, estando originados principalmente por quantidades crescentes de cloreto de sódio e redução do conteúdo de água. Ao completar-se o processo de salga, a taxa de sal existente no tecido muscular se torna praticamente estável, atingindo o estado de equilíbrio osmótico após 8 dias (FUJIMURA et al., 1982).

\subsection{Principais alterações da qualidade do pescado salgado}

Embora o pescado salgado e seco, seja considerado um produto de fácil conservação, não está livre de sofrer deterioração química ou microbiológica, sendo que estas circunstâncias desfavorecem o maior consumo dos produtos da pesca. A penetração do cloreto de sódio nos tecidos é acompanhada por intensa desidratação e precipitação das proteínas musculares, quando em concentrações acima de 8\% (OGAWA \& MAIA, 1999).

Um ponto importante a ser observado é a oxidação dos lipídeos, pois estão relacionados aos aspectos sensoriais, bem como com a diminuição do valor nutricional. Assim, a rancidez oxidativa pode ser apontada como causa de desmerecimento de produtos salgados e secos, pois o odor de ranço pode reduzir a aceitabilidade do pescado. 
De acordo com a quantidade de lipídeos no músculo, os peixes podem ser classificados em magro e gordo. Geralmente, os peixes de carne vermelha, ou seja, que possuem maior quantidade do pigmento muscular mioglobina (principalmente os peixes pelágicos), apresentam alto teor de lipídeo no músculo. Os peixes de carne branca são na maioria, não migratórios, apresentando conteúdo de mioglobina mais baixo e o teor de lipídeos no músculo, abaixo de 1\% (OGAWA \& MAIA, 1999).

Várias reações secundárias podem ser desencadeadas quando se inicia o processo de oxidação lipídica, promovendo a formação de radicais livres e de compostos relacionados ao sabor e odor da carne. Muitos produtos são formados a partir das reações secundárias, sendo que a decomposição dos hidroperóxidos leva ao desenvolvimento do odor característico de ranço devido à formação de álcoois, cetonas, aldeídos e ácidos (TORRES, 1988); são compostos potencialmente tóxicos e que levam à perda de nutrientes (GRAY et al., 1996).

O aldeído mais comumente citado como produto da oxidação lipídica é o malonaldeído, um dialdeído com três carbonos, produzido durante a oxidação secundária dos ácidos graxos polinsaturados (TORRES, 1988). O teste do ácido tiobarbitúrico (TBA) tem sido utilizado para avaliar a oxidação em lipídeos em tecidos musculares. O malonaldeído, neste teste, reage com o TBA formando um pigmento de coloração rósea, cuja intensidade de cor é proporcional à quantidade de oxidação lipídica (GRAY, 1978; TORRES, 1988).

Durante a salga da cavalinha (Scomber japonicusl), BERAQUET et al., (1983) observaram uma tendência de aumento inicial do número de TBA, com posterior decréscimo. Valores máximos situaram-se ao redor de $10 \mathrm{mg}$ de malonaldeído/kg e mínimos ao redor de $4,0 \mathrm{mg}$ de malonaldeído/kg. Atribuíam o decréscimo no valor de TBA após elevação inicial à lixiviação do malonaldeído para a salmoura.

Segundo OGAWA \& MAIA (1999) o processo de oxidação ocorre tanto durante a salga como no decorrer do armazenamento. O cloreto de sódio acelera a reação de rancificação quando presente no músculo de peixes salgados. Cita 
que com valores acima de 1 a $2 \mathrm{mg}$ de malonaldeído/kg, o peixe poderá apresentar odor e sabor característico do ranço.

SIU \& DRAPER (1978) em um estudo sobre os teores de malonaldeído em produtos de pescado fresco, congelado e enlatado, registraram 1,72 mg malonaldeído/1000g, como sendo o maior valor encontrado, corresponde ao salmão fresco previamente congelado. Conforme DENG (1978) na estocagem dos filés de tainha por 9 meses a $-18^{\circ} \mathrm{C}$, o numero de TBA atingiu valor de 8,0.

KELLEHER et al. (1994) relataram que os valores de TBA de 0,9 a 1,5 $\mathrm{mg} / \mathrm{kg}$ foram acompanhados de odor desagradável, porém odores de rancidez apenas ocorreram quando os mesmos se apresentaram acima de 1,5 mg/kg. Foram obtidos para merluza salgada, por meio de salga seca, teores próximos de 1,0 para o TBA, enquanto que para a salga mista, permaneceram ao redor de 0,5 (BOERI et al., 1982).

Não existem normas padronizadas em relação ao grau de oxidação dos lipídeos, que limitem a rancidez de um produto, mas vale ressaltar que a rancidez excessiva não é desejável. Porém, no Brasil, para satisfazer as exigências dos consumidores de peixe salgado é necessária e aceitável alguma rancidez. Conforme a região do País, o peixe salgado, considerado ideal para o consumidor local, é aquele que apresenta "elevado" grau de rancidez, coloração amarelada, sabor acentuado e aroma típico.

ZAPATA et al. (1986) acompanharam a rancidez oxidativa do músculo de tilápia do Nilo e observaram que esta se apresentou baixa durante a moagem e salga, com valores de TBA (mg malonaldeído/kg) compreendidos entra 0,34 e 0,66, havendo um aumento substancial da quantidade de malonaldeído para valores de 3 a 6 logo após a secagem do produto, tanto ao sol como em estufa. A rancidez continuou a aumentar durante a estocagem, atingindo valores máximos de, aproximadamente, 14,0 nos blocos armazenados à temperatura ambiente. A partir de 45 dias de estocagem observaram um decréscimo no número de TBA para este produto. $O$ aumento inicial e a diminuição após um período de estocagem, do número de TBA, segundo SEO (1976) pode ser atribuído às reações do malonaldeído com as proteínas musculares. 
KARAÇAM \& BORAN (1996) citam que os valores de TBA representam o grau de oxidação nos produtos de pescado e os teores acima de 3-4 mg malonaldeído/kg estão relacionados à perda da qualidade. Quando o produto é submetido a salga seca, sua exposição ao ar acelera a oxidação lipídica.

KARAÇAM et al. (2002) estudaram a vida de prateleira e a qualidade das anchovas salgadas a diferentes concentrações e armazenadas por 150 dias a temperatura ambiente e em refrigeração. No final do armazenamento, anchovas mantidas em temperatura ambiente, apresentavam-se com menor qualidade que as amostras salgadas a 22 ou $26 \%$ de concentração de sal e estocadas a $4 \pm 1^{\circ} \mathrm{C}$. Também verificaram, variação nos resultados de TBA das amostras armazenadas a diferentes temperaturas. Embora este teste seja muito utilizado para determinação da rancidez em produtos de pescado, concluíram que talvez não tenha sido efetivo para avaliar a qualidade da anchova nas condições experimentais.

RAVESI \& KRZYNOMEK (1991) estudando o grau de variabilidade de absorção do sal da salmoura em filés de Gadus morhua, Pseudopleuronectes americanus e Sebastes marinus submetidos às concentrações de 5, 10 e 15\% e imersos na salmoura por 30, 60 e 90 segundos. Concluíram que, os dois parâmetros que mais afetaram o teor de $\mathrm{Na}$ dos filés foram a concentração da solução de salmoura e o tempo em que permaneceram na salga. Os maiores valores de $\mathrm{Na}$ foram apresentados para os filés que permaneceram na salga com a maior concentração de sal. Observaram que os filés mais finos absorveram mais sal que os mais grossos, sendo que a pele pode ser uma barreira efetiva contra a penetração de sal no peixe.

As espécies de pescado apresentam cor própria do músculo, líquido corporal, gônodas, vísceras e da pele. Esta diversificação de cor se deve à presença de pigmentos, tais como, carotenóides, hemoglobina, mioglobina, bilinas, hemocianina, etc (OGAWA \& MAIA, 1999).

ZAPATA et al. (1986) verificaram que a cor da polpa salgada de tilápia-donilo mostrou uma tendência para escurecimento durante as fases de secagem e estocagem. Esta mudança foi mais evidente no produto seco em estufa e 
estocado em temperatura ambiente. O escurecimento da fase gordurosa da tilápia salgada e seca também foi observado por MARTINS (s.d.), sendo atribuído à ação de enzimas lipolíticas, reações de rancidez oxidativa ou interações de lipídeos com proteínas.

O sal incorporado ao produto em conservação acima de 15\%, inibe 0 desenvolvimento de bactérias patogênicas e das envolvidas no processo de putrefação, pela redução da atividade de água (OGAWA \& MAIA, 1999). A atividade de água limitante para as bactérias halófilas e bolores deterioradores do pescado salgado é de 0,70 (VARGA et al., 1979).

As bactérias halófilas que fazem parte da microbiota normal do sal, são responsáveis pela chamada deterioração vermelha do pescado (WATABE, 1980) uma vez que manchas avermelhadas aparecem na sua superfície, tornando-o passível de rejeição. LEITÃO (1995) discute os principais problemas relacionados à microbiologia do pescado salgado, citando a classificação dos principais microorganismos halófilos como sendo: ligeiramente halófilos, moderadamente halófilos e extremamente halófilos, podendo crescer, respectivamente, em meios contendo $2-5 \%$ de sal, 5-20\% de sal e $20-30 \%$ de sal. O autor ainda cita as bactérias halotolerantes, capazes de crescimento tanto em meios contendo concentrações maiores que $5 \%$ de $\mathrm{NaCl}$, como naqueles isentos de sal.

Além das bactérias, existem espécies de bolores e leveduras sal-tolerantes, que podem deteriorar o pescado salgado (LESSI, 1995). Muitas perdas nesse tipo de produto são causadas por crescimento visível de bolores na superfície, provocando descolorações e pontos pretos, tornando-os inaceitáveis para o consumidor ou pelo menos tendo o seu valor comercial diminuído.

A atividade de água $\left(A_{a}\right)$ tem sido considerada como uma propriedade fundamental no controle de qualidade de alimentos, especialmente em relação à conservação dos produtos curados. A incorporação de sal ( $\mathrm{NaCl}$ ) ao tecido do pescado produz um efeito de desidratação pelo estabelecimento de um gradiente osmótico. Ocorre a entrada de sal no interior das células e aumento na pressão osmótica, provocando a saída de água dos tecidos, diminuindo a atividade de água no músculo e, conseqüentemente, limitando o crescimento de 
microrganismos (FERREIRA \& OETTERER, 1992; ANDRÉS et al., 2002). A desidratação osmótica ainda é importante para assegurar a qualidade do alimento, a preservação do produto e a preferência do consumidor. Desta forma, o teor de sal deveria ser capaz de reduzir a $A_{a}$ da carne para 0,97 ou menos. Para 0 produto ser considerado estável ou seguro para seu armazenamento em temperatura ambiente, é necessário que a $A_{a}$ seja menor que 0,85 (FRANCO \& LANDGRAF, 2003).

No pescado seco, salgado, salgado e seco usualmente encontramos valores de $A_{a}$ iguais ou inferiores a 0,75 ; nenhuma deterioração é esperada nestes valores de $A_{a}$, pelas bactérias pertencentes à microbiota normal do pescado. Porém, o peixe salgado pode ser deteriorado pelas bactérias halofílicas (bactérias que crescem em ambientes com elevada concentração de sal), as quais podem crescer nestes valores de $A_{a}$.

O crescimento microbiano está relacionado diretamente com a atividade de água. O sal que é acrescentado ao pescado durante o processamento diminui a atividade de água do sistema, e desta forma a possibilidade de vida dos microrganismos. Porém, a qualidade do sal utilizado na salga influi deterioração do produto, pois pode apresentar um teor de impurezas e contaminação por microrganismos. O cloreto de sódio puro não absorve muita umidade do ar, exceto se a umidade do meio for superior a $76 \%$. O sal empregado no processo de cura geralmente contém impurezas como cloretos e sulfatos de cálcio e magnésio, que absorvem vapor de água em umidades relativas menores que $76 \%$. Portanto, se o produto for tratado com sal contendo impurezas, poderá haver reabsorção de umidade do ar, e poderão se desenvolver microrganismos halófilos indesejáveis.

Uma bactéria halófila capaz de provocar um odor desagradável na superfície do pescado é a Serratia salinaria que produz uma espécie de limo conhecido por "vermelhão". Este microrganismo é introduzido no produto através do sal, é aeróbio, e se desenvolve quando o produto está em contato com o ar e em temperatura acima de $10^{\circ} \mathrm{C}$ (FRANCO \& LANDGRAF, 2003). 
Outra forma de alteração comum em produtos fracamente salgados, é o aparecimento de pequenas manchas negra ou castanho-escuro, como se fossem grânulos de pimenta-preta. Essas manchas são provocadas por microorganismos, e apesar de não decomporem a carne, conferem uma má aparência ao produto. Uma adequada higiene do local de cura e armazenamento pode evitar esse tipo de problema (FRANCO \& LANDGRAF, 2003).

A forma mais comum de alteração em produtos salgados é o que se denomina de "ferrugem" ou rancificação. Esta aparece como uma coloração castanha no pescado. O sal pode agir como catalisador dessa alteração. Numa etapa inicial, a "ferrugem" aparece na superfície do pescado, quando ainda não há manifestação de sinais desagradáveis. Utilizando o bicarbonato de sódio, pode-se lavar a superfície, mas quando existe penetração e espalhamento, torna-se inaceitável. O meio mais efetivo de se prevenir esse problema é o de evitar o contato do pescado com o ar durante e após o processamento.

Em uma pesquisa realizada com treze diferentes tipos de pescados salgados e vendidos como "bacalhau" foi detectado muitos problemas a começar pela rotulagem do produto. As análises laboratoriais revelaram excesso de umidade e de teor de sal (cloreto de sódio), início de degradação, alterações de conservação e presença de microrganismos. Quanto às análises microbiológicas foram estudadas a presença de bactérias halofílicas, coliformes, E.coli, bolores e leveduras, clostrídios sulfito-redutores, salmonela e estafilococos. Foram encontrados microrganismos halofílicos em dois desses peixes e a presença de bolores e leveduras em outros quatro. A maior dificuldade, porém foi obter respaldo na legislação brasileira que não define um limite máximo de sal, ignora algumas alterações de preparo e conservação que podem aparecer no peixe, como fendas e parasitas, e não estipula parâmetros para controlar o frescor do peixe salgado seco. Com relação aos padrões microbiológicos, há outra resolução da Agência Nacional de Vigilância Sanitária (ANVISA), que também possui falhas. Esta não estipula limites para a presença de bactérias halófilas, bolores e leveduras, clostrídios sulfito-redutores e permite concentrações altas de coliformes e estafilococos (ANÔNIMO, 2004). 
O Staphylococcus aureus é uma bactéria de grande importância em surtos de infecções alimentares. Por se encontrarem presentes principalmente nas mãos e garganta de manipuladores de alimentos, a contaminação por esses microorganismos está largamente relacionada à manipulação inadequada dos produtos pesqueiros. $O$ crescimento de $S$. aureus nos alimentos representa um risco potencial à saúde humana, devido a enterotoxina produzida e introduzida, via alimento, responsável pelo quadro de intoxicação alimentar (VIEIRA, 2004).

ZAPATA et al. (1986) verificaram que as análises microbiológicas evidenciaram um alto grau de contaminação bacteriana dos peixes utilizados no processo da salga, apresentando valores, em alguns casos, acima do limite permitido para comercialização deste tipo de alimento. $O$ processo de salga e secagem produziu uma diminuição do número de bactérias mesófilas e uma completa inibição de coliformes, clostrídios sulfito-redutores e Staphylococcus aureus. Não foi detectada a presença de Salmonella neste estudo. A flora predominante do produto salgado e seco foi constituída de bactérias halofílicas e alguns bolores e leveduras, fato decorrente, provavelmente, da baixa atividade de água e alta concentração de sal no produto. Durante a estocagem houve diminuição do nível de bactérias mesófilas e aumento das halófilas, sendo que este efeito foi mais acentuado no produto estocado à temperatura ambiente que no estocado sob refrigeração. O nível de halófilos neste produto foi considerado alto no final dos 90 dias de estocagem e com tendência a aumentar com o tempo de armazenamento. 


\section{MATERIAL E MÉTODOS}

\subsection{Local do experimento}

O experimento foi conduzido nas dependências da Faculdade de Zootecnia e Engenharia de Alimentos da Universidade de São Paulo (FZEA/USP), Campus Administrativo de Pirassununga, Pirassununga (SP), no período de setembro de 2004 a fevereiro de 2005.

\subsection{Material}

Os peixes foram concedidos pela Estação de Hidrobiologia e Aqüicultura de Salto Grande (SP). Os animais foram abatidos no local de captura, sendo imersos em água e gelo (1:1) por 1 hora e acondicionados em gelo moído. No mesmo dia foram transportados para o Matadouro Escola pertencente à Prefeitura do Campus Administrativo de Pirassununga. Após a limpeza e filetagem foram transferidos para o Laboratório de Bromatologia do Departamento de Zootecnia (ZAZ), onde permaneceram até o final do experimento.

\subsection{Métodos}

\subsubsection{Processamento preliminar}

Todos os animais foram eviscerados, descamados, descabeçados e pesados em uma balança da marca Marte, com capacidade de $2000 \mathrm{~g}$ (precisão de $0,01 \mathrm{~g}$ ). Os peixes limpos e inteiros foram pesados e seus pesos anotados.

Após serem pesados, os peixes foram filetados. O processo da filetagem foi realizado por uma única pessoa, e não havendo a separação da musculatura dos ossos da coluna vertebral. Todos os cuidados foram tomados para que não fosse rompida a cavidade abdominal, evitando a contaminação dos filés pelo próprio conteúdo intestinal. De cada peixe foram obtidos dois filés com pele, que foram 
pesados individualmente para a avaliação do rendimento. Os filés foram identificados e numerados para a retirada aleatória de amostras no decorrer do experimento. Todos os pesos dos peixes inteiros e dos filés foram utilizados para os cálculos de rendimento.

\subsubsection{Salga em salmoura saturada e salga seca}

Foram empregadas 36 piracanjubas (Brycon orbygnianus), sendo 18 exemplares para a salga em salmoura saturada (ou salga úmida) e 18 para a salga seca, pesando em média 584,9 g e 580,4 g, respectivamente.

\subsubsection{Salga em salmoura saturada}

\section{- Preparo da salmoura saturada (30\%)}

A salmoura foi preparada utilizando-se sal grosso comercial, triturado em um liquidificador industrial de inox e submetido à secagem em estufa a $100^{\circ} \mathrm{C}$, por 2 horas, para esterilização. No processo de salga em salmoura foi empregada a proporção de 2:1 (salmoura: filé).

\section{- Processo de salga e secagem}

Para o processo de salga em salmoura saturada (ou salga úmida), os filés foram colocados em uma caixa plástica e sobre estes, a salmoura saturada (Figura 2). Duas tábuas de madeira, envolvidas em um filme plástico, foram colocadas sobre os peixes, na extremidade superior do recipiente permitindo que todos os peixes ficassem imersos na salmoura por, aproximadamente, 168 horas (7 dias). Estes peixes não foram submetidos à prensagem, por já estarem com os teores de água muito reduzidos. Após este período, os filés foram secos em estufa com circulação forçada de ar, em temperatura de $40^{\circ} \mathrm{C}$, por 48 horas. A estocagem dos mesmos ocorreu em temperatura ambiente por 45 dias. 


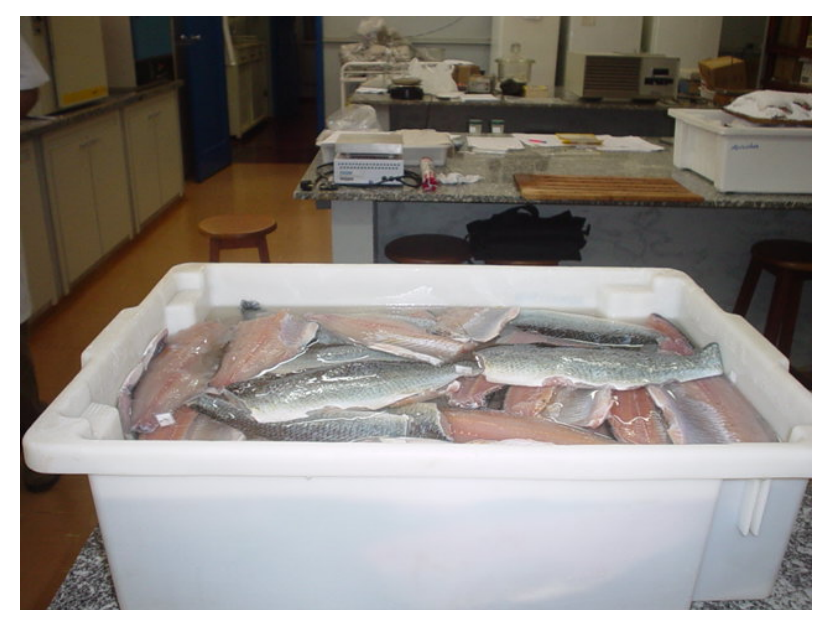

Figura 2 - Filés de piracanjuba submetidos à salga úmida.

Para avaliação do rendimento do processamento, cinco filés foram amostrados aleatoriamente, separados para pesagem inicial e nos mesmos tempos de coleta das amostras.

\subsubsection{Salga seca}

O procedimento para a salga seca deu-se colocando os filés em uma pilha sobre uma madeira perfurada, sendo intercalados por camadas de sal grosso preparado do mesmo modo que para salga em salmoura saturada. A primeira e a última camada da pilha foram constituídas pelo sal (Figura 3).

Os peixes permaneceram desta maneira por cerca de 168 horas (7 dias), quando terminou o processo da salga. Estes peixes também não foram submetidos à prensagem, por já estarem com os teores de água muito reduzidos. Para este tipo de salga, a secagem foi realizada por 48 horas, em estufa $\left(40^{\circ} \mathrm{C}\right)$ com circulação forçada de ar, e a estocagem por 45 dias nas mesmas condições descritas para o processo da salga em salmoura saturada. 

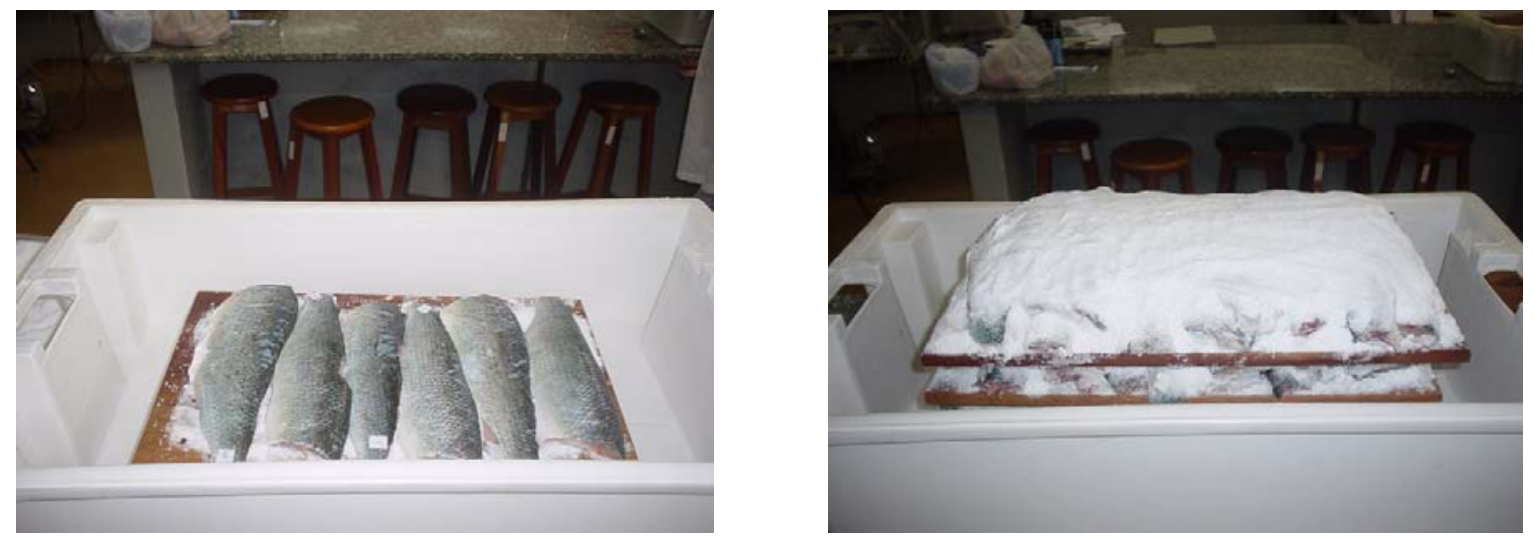

Figura 3 - Filés de piracanjuba submetidos à salga seca.

Para avaliação do rendimento do processamento, cinco filés foram amostrados aleatoriamente, separados para pesagem inicial e nos mesmos tempos de coleta das amostras.

\subsubsection{Acompanhamento do processo de salga}

O processo de salga foi acompanhado, por um período de 7 dias, sendo retiradas amostras aleatórias de 3 filés de cada tipo de salga, em tempos prédeterminados, a saber: T0 (peixe fresco/tempo zero do processo de salga), T3, T6, T12, T20, T24, T36, T48, T72, T96, T120, T144 e T168 horas após o início da salga, respectivamente, para a salga em salmoura saturada e salga seca. Ainda, para a salga úmida em todos os períodos de coleta de amostra dos filés, também eram retiradas amostras da salmoura para análise do $\mathrm{pH}$, teor de cloreto de sódio e da concentração de proteína solúvel.

\subsubsection{Análises químicas, físicas e microbiológicas}

Os filés, após terem sido submetidos ao processamento da salga em salmoura saturada e salga seca, foram amostrados aleatoriamente e analisados para: 
Composição centesimal - A composição centesimal foi realizada, em triplicata, na matéria prima inicial (peixe fresco/tempo zero do processo de salga); T0, T30 e T45, respectivamente, para início (ou após a secagem), 30 dias e final do armazenamento, segundo as técnicas preconizadas pela AOAC (1995). As análises foram:

a) Umidade - determinada pelo método da perda de peso da amostra após aquecimento por 16 horas na estufa a $105^{\circ} \mathrm{C}$, até atingir peso constante.

b) Proteína bruta - para determinação do nitrogênio total, pelo método de Kjeldahl e aplicação do fator 6,25 para obtenção de proteína bruta (PB).

c) Extrato etéreo - a gordura (EE) foi extraída com éter de petróleo, pelo método de Soxhlet, com refluxo contínuo por 6 horas.

d) Cinzas - para análise de cinzas ou matéria mineral (MM), a amostra seca foi colocada na mufla $\left(500-550^{\circ} \mathrm{C}\right)$ até obtenção de peso constante.

e) Macro e microminerais - As amostras foram submetidas à digestão úmida nitroperclórica e posterior diluição (AOAC, 1995). As leituras para os minerais cálcio $(\mathrm{Ca})$, ferro $(\mathrm{Fe})$, zinco $(\mathrm{Zn})$, cobre $(\mathrm{Cu})$, manganês $(\mathrm{Mn})$, magnésio $(\mathrm{Mg})$ foram realizadas em espectrofotômetro de absorção atômica, marca Perkin-Elmer, modelo AA100. O fósforo $(P)$ foi analisado colorimetricamente, de acordo com metodologia de FISKE \& SUBBAROW (1925) e as determinações de sódio e potássio através de fotometria de chama (marca Analyser, modelo 910).

Cloreto de sódio - As análises de cloreto de sódio $(\mathrm{NaCl})$ foram feitas em duplicatas na matéria prima inicial, nas amostras de salmoura e filés durante 0 processo de salga, e apenas nos filés, após a etapa de secagem e durante o armazenamento, em intervalos de 15 dias. A metodologia empregada foi a do 
método argentométrico de Mohr (LANARA, 1993), pelo uso de uma solução padronizada de nitrato de prata e de cromato de potássio a $0,1 \%$, como indicador.

Proteína solúvel na salmoura - A concentração de proteína na salmoura do processo de salga em salmoura saturada foi quantificada pelo processo de BRADFORD (1976).

Substâncias reativas ao ácido tiobarbitúrico - Para análise das substâncias reativas ao ácido tiobarbitúrico (TBARS) utilizou-se a metodologia descrita por VYNCKE (1970). Esta avalia a tendência da oxidação dos lipídios. As análises foram realizadas em triplicatas no músculo fresco, e tanto para a salga em salmoura saturada como para a seca, as avaliações para TBARS foram feitas em amostras da matéria prima inicial, no decorrer do processo de salga, após a etapa de secagem e durante o armazenamento a cada 15 dias.

Nitrogênio não protéico - A determinação do nitrogênio não protéico (NNP) foi realizada após a separação da fração protéica, que é precipitada por ácido tricloroacético a $10 \%$, e no filtrado podem ser determinados os compostos mais importantes, ou NNP total, sendo necessário, neste caso, realizar a digestão de uma alíquota do filtrado e proceder como para determinação de nitrogênio total (HORWITZ, 1980).

Bases nitrogenadas voláteis - $\mathrm{O}$ método para análise de bases nitrogenadas voláteis (N-BVT) permite determinar o teor de substâncias básicas voláteis, geralmente amônia e aminas de cadeia curta que se acumulam nos músculos dos pescados após a morte (HOWGATE, 1976).

Atividade de água - As amostras foram trituradas previamente e a atividade de água $(\mathrm{Aa})$ foi determinada por medida direta em aparelho Aqualab Cx-2, pertencente ao laboratório de Tecnologia de Alimentos (FZEA/USP). 
Calorimetria diferencial de varredura - Para as análises por calorimetria diferencial de varredura, uma alíquota de $10 \mathrm{mg}$ era retirada de cada amostra recém-preparada, colocadas em panelinha TA de alumínio, fechadas hermeticamente e pesadas $( \pm 0,01 \mathrm{mg}$ ) em balança de precisão (Ohaus, Analytical Plus). Essas análises foram realizadas em um calorímetro diferencial de varredura DSC-TA2010, com controlador TA5000 (TA Instruments), operando com fluxo de $45 \mathrm{~mL} / \mathrm{min}$ de $\mathrm{N}_{2}$, taxa de aquecimento de $10^{\circ} \mathrm{C} / \mathrm{min}$, entre 0 e $100^{\circ} \mathrm{C}$ e com uma panelinha vazia como referência. O aparelho foi calibrado com Índio $\left(T=156,6^{\circ} \mathrm{C}\right.$ e $\Delta \mathrm{H}=28,71 \mathrm{~J} / \mathrm{g})$. Considerou-se como temperatura $(\mathrm{Td})$ e entalpia $(\Delta \mathrm{Hd}) \mathrm{de}$ desnaturação, a temperatura onde ocorreu o pico e a área sobre as endotermas, respectivamente, ambos calculados com emprego do programa do Universal Analysis V.2.5H (TA Instruments). As análises para o peixe fresco e os filés de piracanjuba, submetidos à salga úmida e seca, para os tempos 6, 12 e 168 horas após o início da salga, foram realizadas em triplicata.

Análises microbiológicas - As análises microbiológicas foram realizadas no Laboratório de Microbiologia do Leite (FZEA/USP). Para estes testes, foram colhidas amostras dos tempos T0 (peixe fresco), T0 e T30 do armazenamento, em triplicata. Para isto sortearam-se três filés para coleta das amostras nos referidos tempos para a salga seca e úmida.

Como procedimento analítico, as amostras (25 g) foram adicionadas a um erlenmeyer contendo $125 \mathrm{~mL}$ de água peptonada (1 \%) e o sistema foi homogeneizado por cerca de um minuto. Esta solução foi considerada como diluição $10^{-1}$. A partir dessa solução foram obtidas as diluições seriadas $10^{-2}$ e $10^{-3}$. Realizaram-se então os testes para coliformes totais e fecais, Clostridium e Staphylococcus aureus. O erlenmeyer contendo o restante da diluição $10^{-1}$ foi incubado a $35^{\circ} \mathrm{C}$ por 24 horas para a realização dos testes para Salmonella (SILVA et al., 2001).

As análises microbiológicas, para se verificar a presença das bactérias halófilas (DOWNES \& ITO, 2001), foram realizadas no Instituto de Tecnologia de Alimentos (ITAL/Campinas). 


\subsubsection{Rendimento do processamento}

A partir do início do experimento, após o processo de salga e secagem, os filés com pele foram pesados. O rendimento (\%) de filé foi calculado a partir dessas pesagens e em função do peso total de cada peixe (eviscerados e descabeçados).

\subsubsection{Delineamento experimental e análise estatística}

Foram utilizados 36 exemplares de piracanjuba, separados em 72 filés, distribuídos em dois tratamentos (salga em salmoura saturada e salga seca).

Para o processamento, utilizou-se um delineamento inteiramente casualizado com dois tratamentos (salga seca e salga úmida) avaliados em 13 tempos $(0,3,6,12,20,24,36,48,72,96,120,144$ e 168 horas) e três repetições (filés) por tratamento.

Os dados de umidade, cloreto, substâncias reativas ao ácido tiobarbitúrico e atividade de água foram analisados utilizando-se uma abordagem de modelo com medidas repetidas, justificada pela possível heterogeneidade das variâncias dessas medidas nas diversas ocasiões.

Nas análises utilizou-se o proc mixed do SAS (2000), sendo que na presença de interação entre os tratamentos e as ocasiões, procedeu-se ao seu desdobramento, com o intuito de comparar os dois tratamentos nas diversas ocasiões, utilizando-se o teste t-Student. Adotou-se o nível de significância de 5\%, sendo os resultados apresentados em gráficos com os valores médios e seus respectivos erros padrões.

Para os dados de proteína solúvel e cloretos obtidos para a salmoura foram utilizados os mesmos procedimentos analíticos que para os filés durante 0 processamento. Quanto ao armazenamento, adotou-se um delineamento inteiramente casualizado com dois tratamentos (salga seca e salga úmida) avaliados em quatro tempos ( $0,15,30$ e 45 dias) e três repetições (filés) por tratamento. 
As variáveis composição centesimal e minerais foram analisadas nos tempos 0, 30 e 45 dias do armazenamento; cloreto, substâncias reativas ao ácido tiobarbitúrico e atividade de água, aos 0, 15, 30 e 45 dias de armazenamento e as bases nitrogenadas voláteis e nitrogênio não protéico, avaliados somente aos 0 e 30 dias de armazenamento.

Os dados das referidas variáveis foram analisados utilizando-se uma abordagem de modelo com medidas repetidas, justificada pela possível heterogeneidade das variâncias dessas medidas nas diversas ocasiões. Nas análises utilizou-se o proc mixed do SAS (2000), sendo que na presença de interação entre os tratamentos e os tempos, procedeu-se ao seu desdobramento, com o intuito de comparar os dois tratamentos nas diversas ocasiões, utilizandose o teste t-Student.

Adotou-se o nível de significância de 5\%, sendo os resultados apresentados em tabelas ou gráficos com os valores médios e seus respectivos erros padrões. As análises microbiológicas das bactérias halofílicas, Clostrídio sulfito redutor, Staphilococcus aureus, Salmonella sp, Coliformes totais e Coliformes fecais foram realizadas aos 0 e 30 dias do armazenamento e os resultados médios foram apresentados em tabela. Para o peixe fresco foram realizadas todas as análises citadas, exceto a das bactérias halofílicas.

Os dados de rendimento foram analisados e comparados pelo teste tStudent no final dos períodos de processamento e de armazenamento das salgas seca e úmida.

O fluxograma do procedimento da salga e as amostragens para as análises laboratoriais estão apresentados na Figura 4. 

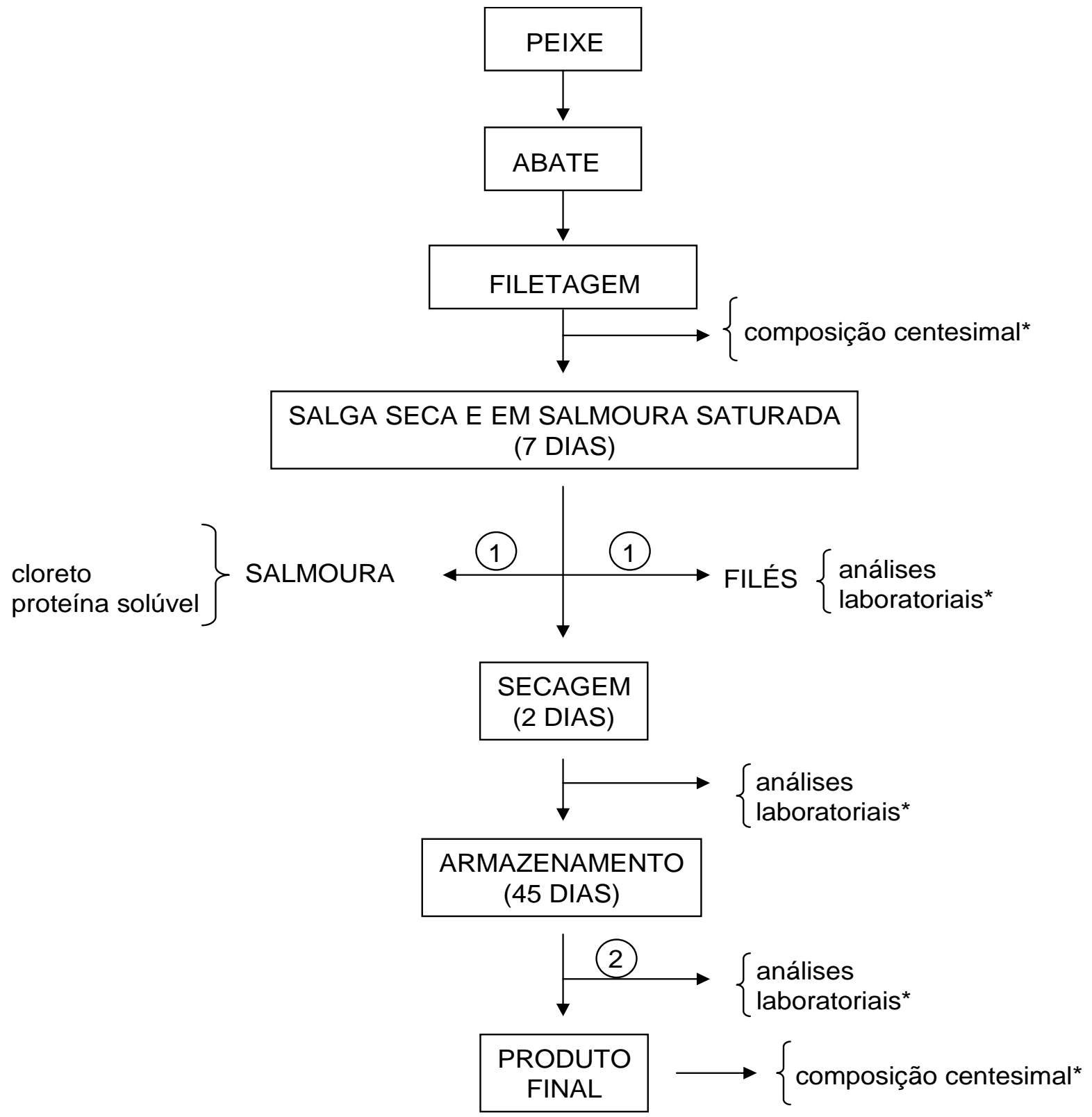

(1) Amostragem efetuada nos tempos (horas): T0, T3, T6, T12, T20, T24, T36, T48, T72, T96, T120, T144 e T168 após o início da salga.

(2) Amostragem efetuada nos tempos (dias): T0, T15, T30 e T45 do armazenamento.

* Análises detalhadas no Material e Métodos.

Figura 4 - Fluxograma do processamento da salga em piracanjuba (Brycon orbignyanus). 


\section{RESULTADOS E DISCUSSÃO}

\subsection{Processamento}

A maturação natural do processo de salga começa assim que o pescado entra em contato com o sal e/ou solução salina e a água do sistema. A seguir, ocorre a formação do sistema: sal-pescado ou salmoura-pescado, influenciado por um conjunto de trocas bioquímicas. Esse processo continua durante todo o período de armazenamento do produto e irá resultar na produção do pescado salgado. O cloreto de sódio é um dos componentes mais importantes na determinação das características organolépticas do produto final. 0 desenvolvimento da salga dos filés de piracanjuba foi monitorado para as duas salgas (úmida e seca) pelo período de 7 dias, correspondendo a 168 horas de processamento, por meio de uma série de análises, descritas a seguir, visando acompanhar a qualidade do pescado.

A relação cloreto/umidade dos filés de piracanjuba durante 0 processamento pode ser observada na Tabela 1. Os valores para as duas salgas mostram-se bastante próximos desde o início do processamento com aumentos constantes e terminando com valores exatamente iguais após a secagem.

SALES et al. (1986), citando FREITAS et al. (1986) consideraram como ideal, para conservação do pescado salgado seco, a relação sal/umidade situada na faixa de 0,39 a 0,42. No decorrer do processamento dos filés de piracanjuba, estes valores foram atingidos para o tempo de 48 horas para a salga seca $(0,39)$ e de 72 horas para a salga úmida $(0,42)$ (Tabela 1$)$. 
Tabela 1 - Valores médios de umidade (\%), cloreto (\%) e relação cloreto/umidade dos filés de piracanjuba submetidos à salga úmida (SU) e seca (SS) durante o processamento (horas).

\begin{tabular}{|c|c|c|c|c|c|c|}
\hline \multirow[b]{2}{*}{ Horas } & \multicolumn{2}{|c|}{ Umidade (\%) } & \multicolumn{2}{|c|}{ Cloreto (\%) } & \multicolumn{2}{|c|}{$\begin{array}{l}\text { Relação } \\
\text { cloreto/umidade }\end{array}$} \\
\hline & su & SS & su & SS & su & SS \\
\hline 0 & 77,15 & 77,15 & 3,50 & 3,50 & 0,05 & 0,05 \\
\hline 3 & 71,84 & 70,69 & 11,88 & 10,68 & 0,17 & 0,15 \\
\hline 6 & 66,58 & 65,88 & 16,20 & 16,15 & 0,24 & 0,25 \\
\hline 12 & 65,6 & 58,21 & 17,49 & 18,27 & 0,27 & 0,31 \\
\hline 20 & 60,13 & 55,67 & 18,70 & 18,46 & 0,31 & 0,33 \\
\hline 24 & 60,43 & 54,44 & 19,78 & 19,65 & 0,33 & 0,36 \\
\hline 36 & 59,74 & 53,58 & 22,00 & 19,25 & 0,37 & 0,36 \\
\hline 48 & 59,32 & 51,32 & 21,46 & 20,10 & 0,36 & 0,39 \\
\hline 72 & 56,82 & 48,59 & 23,66 & 22,04 & 0,42 & 0,45 \\
\hline 96 & 59,18 & 49,95 & 24,36 & 24,03 & 0,41 & 0,48 \\
\hline 120 & 36,05 & 49,36 & 19,21 & 22,70 & 0,53 & 0,46 \\
\hline 144 & 52,02 & 47,23 & 21,27 & 21,38 & 0,41 & 0,45 \\
\hline 168 & 49,17 & 43,18 & 23,86 & 21,08 & 0,49 & 0,49 \\
\hline $\begin{array}{c}\text { Após } \\
\text { secagem }\end{array}$ & 47,38 & 37,29 & 23,69 & 18,61 & 0,50 & 0,50 \\
\hline
\end{tabular}


Conforme consta da Tabela 1 os valores de umidade, no tempo 0 do processamento, era de $77,15 \%$ para os dois tratamentos, sendo que 168 horas após o início da salga, este valores foram reduzidos para 49,17\% para a salga úmida e de $43,18 \%$, para a seca. A diminuição dos teores de umidade dos filés ocorreu de forma semelhante nos dois processos até 6 horas de salga, tornandose mais intensa na salga seca a partir deste momento, até o final do processamento. Os filés de piracanjuba após secagem continham 47,38\% e $37,29 \%$ de umidade, nessa ordem, para a salga úmida e seca. Houve uma diminuição nos teores de umidade para os filés de piracanjuba durante a salga úmida e seca, durante todo o processamento.

Os valores médios de umidade nos filés de piracanjuba estão apresentados na Figura 5. A análise estatística permitiu a observação de diferença significativa e interação $(p<0,05)$ entre os tratamentos (salga seca e úmida) e entre o tempo de processamento (horas). No desdobramento das interações não foi identificada diferença significativa $(p>0,05)$ entre os tempos de $0,6,12$ e 144 horas de processamento, sendo que nos demais, a salga úmida apresentou valores médios de umidade superiores à seca.

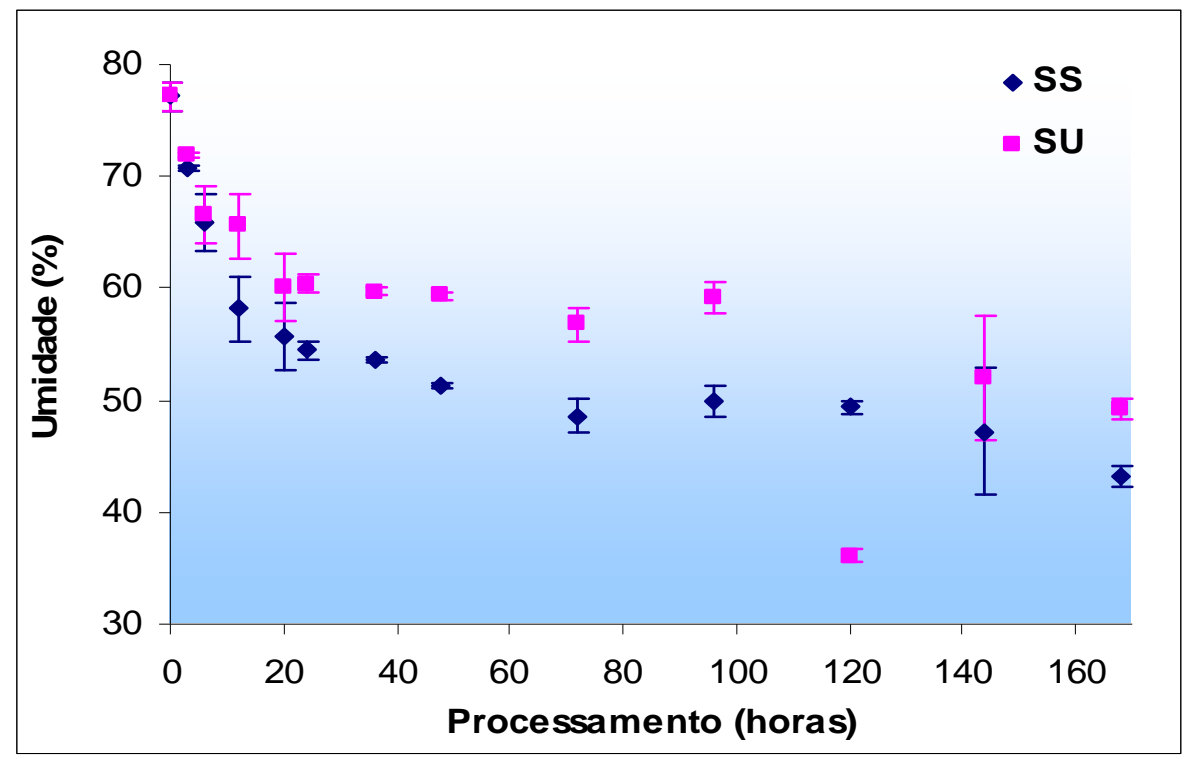

Figura 5 - Valores médios de umidade (\%) e erro padrão dos filés de piracanjuba submetidos à salga seca (SS) e úmida (SU) durante o processamento. 
Na salga úmida há uma variação de peso, sendo que no início há uma diminuição do mesmo para depois aumentar devido à penetração do sal, aumento/redução de umidade na carne, dissolução de proteína, dentre outros fatores, etc. Também se observa na salga seca, uma tendência de redução de peso do produto. Dependendo da concentração do sal, esta redução pode atingir valores de cerca de $30 \mathrm{~g} / 100 \mathrm{~g}$ quando comparada à carne fresca e um conteúdo de umidade entre 55-60\%, alcançando valores entre $30-40 \%$ conforme a qualidade do sal que for aplicado (OGAWA \& MAIA, 1999). Esse comportamento foi observado no presente estudo durante o desenvolvimento do processo para as duas salgas.

BJ $\varnothing$ RKEVOLL et al. (2003) cita que os valores para o conteúdo de umidade podem ser reduzidos também por secagem e quando esse processo é realizado, esses teores podem ser inferiores a $50 \%$, sendo o produto final denominado "bacalhau curado salgado e seco". Neste estudo com a piracanjuba, os teores finais de umidade, após a secagem, ficaram abaixo de $50 \%$, podendo ser considerados produtos curados salgados e secos.

FUJIMURA et al. (1982) e BURGESS et al. (1967) relatam que a composição química e o peso do pescado salgado apresentam mudanças durante o processo de salga e armazenamento, estando originados por quantidades crescentes de cloreto de sódio e redução do conteúdo de umidade de água. A velocidade de transporte do sal é influenciada por vários fatores como teor de gordura, espessura do filé, concentração e temperatura da salmoura e pureza química do sal (MACHADO, 1984). SHENDERYUK \& BYLOWSKI (1994) relatam que a presença de pele no pescado pode contribuir com os fatores citados reduzindo em até 1,6 vezes o teor de sal que penetra no músculo.

Os valores médios de porcentagem de cloreto durante o processamento podem ser visualizados na Figura 6. Foi constatado após a análise estatística dos dados que houve diferença significativa $(p<0,05)$ apenas entre as horas do desenvolvimento das salgas. 


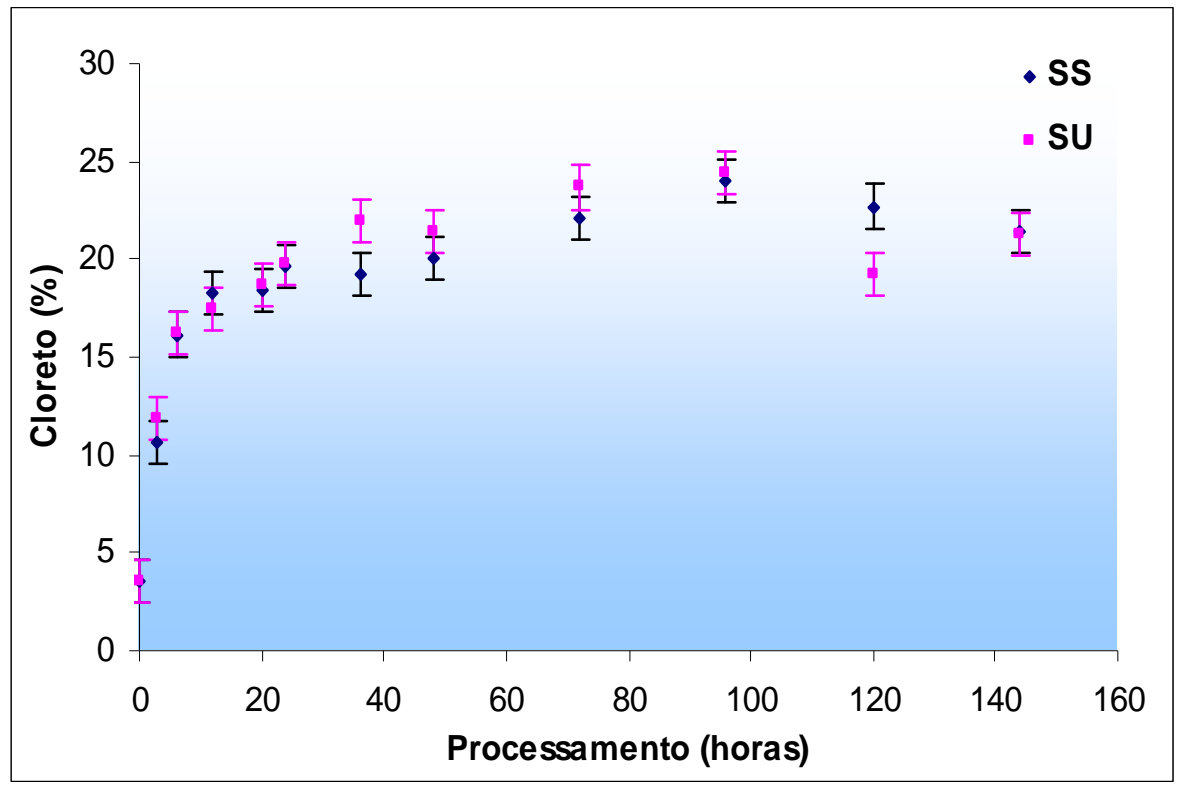

Figura 6 - Valores médios de cloreto (\%) e erro padrão dos filés de piracanjuba submetidos à salga seca (SS) e úmida (SU) durante o processamento.

O valor inicial do cloreto presente no músculo aumentou com o decorrer do processo de salga, apresentando tendência de estabilização desses teores entre $20-24 \%$, a partir das 48 horas, tempo este em que o equilíbrio osmótico pode ter sido atingido (Tabela 1). Comportamento semelhante foi verificado por MACEDOVIEGAS (2004) durante o processamento da tilápia do Nilo, porém o equilíbrio osmótico para a salga seca e úmida, foi atingido, respectivamente, a partir das 36 e 72 horas e, com aproximadamente, 14\% de cloreto. BJøRKEVOLL et al. (2003) também encontraram valores de $20-22 \%$ e de $22-25 \%$ de sal para o bacalhau (Gadus morhua) salgado e salgado-seco, respectivamente, após 48 horas de salga. O teor de sal obtido para os filés de piracanjuba salgado, nesse período, para a salga seca, foi de $20,10 \%$, portanto um pouco abaixo do referido valor.

Segundo BURGUESS et al. (1967) a concentração de cloreto de sódio no interior de filé de $2,5 \mathrm{~cm}$ de espessura pode alcançar $10 \%$, depois de 24 horas na salmoura. Valores semelhantes foram obtidos por MACEDO-VIEGAS (2004) para os filés de tilápia do Nilo, com espessura de $2 \mathrm{~cm}$, valores de $10 \%$ e $8 \%$, para a salga úmida e seca, respectivamente, para um dia de salga úmida. Porém, essa 
situação não foi observada neste experimento com filés de piracanjuba, visto que a espessura dos mesmos esteve ao redor de $1,5 \mathrm{~cm}$ e, com 24 horas de salga, os filés apresentaram valores 19,78\% de cloreto de para a salga úmida e de 19,65\%, para a seca. Pequenas variações nos teores de cloretos foram detectadas após as 24 horas de salga, atingindo o máximo com 96 horas, seguidos por ligeiros decréscimos até 168 horas de processamento.

SANNAVEERAPPA et al. (2004) relataram valores de cloreto de 5,32\% para a salga úmida e de 10,32\% para a seca ao estudarem a salga do "milkfish" (Chanos chanos). O conteúdo de umidade apresentou redução de 76,60\% (início da salga) para $62,55 \%$ e de $60,96 \%$, respectivamente para a salga seca e úmida. Segundo estes autores, ocorre perda significativa de quantidades de proteínas, peptídeos e de aminoácidos, e essas perdas são maiores na salga úmida que na seca.

Os valores médios de porcentagem de cloreto nos filés de piracanjuba submetidos ao processo de salga em salmoura saturada e na salmoura estão apresentados na Figura 7. Pode-se visualizar que na salmoura os valores de cloreto tenderam a se apresentar constantes havendo pouca variação. Verifica-se que em relação à porcentagem de cloreto nos filés, a análise estatística e a de regressão permitiram observar que os valores máximos foram alcançados após 48 horas de processamento. A partir desse período, os valores de cloreto apontam para uma estabilização na quantidade de cloreto absorvido. 


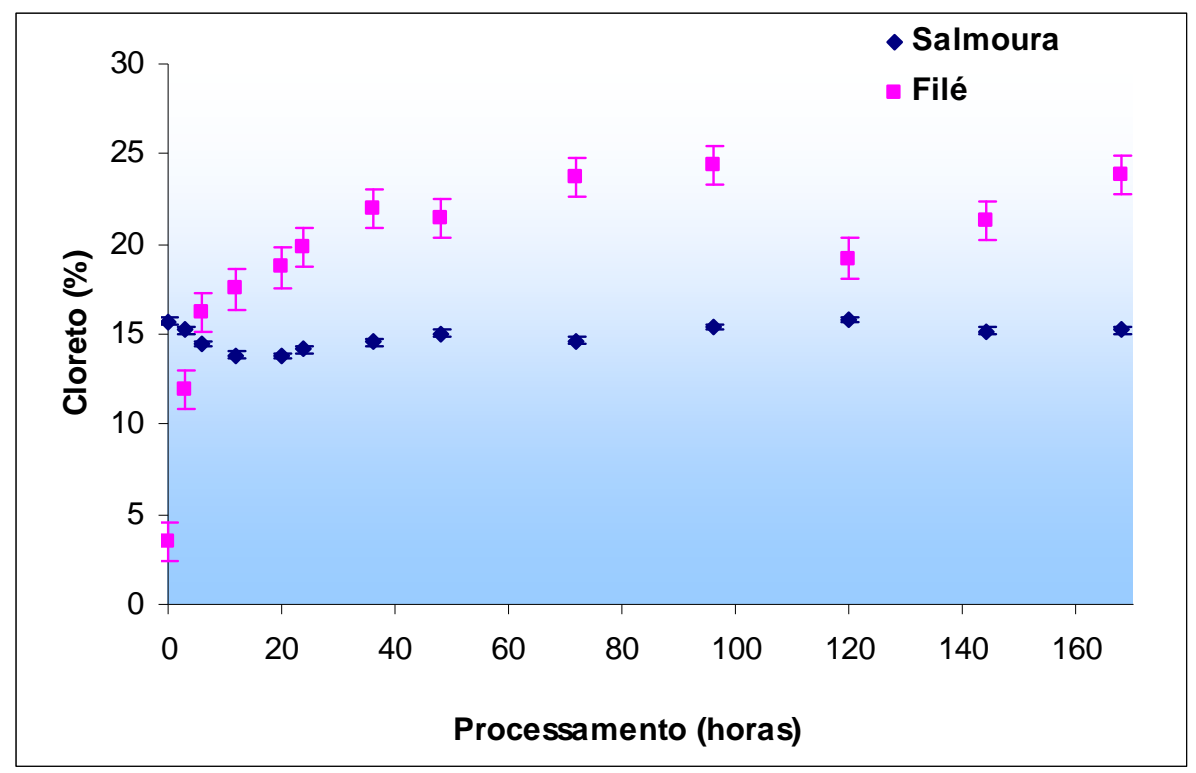

Figura 7 - Valores médios de cloreto (\%) e erro padrão dos filés de piracanjuba submetidos à salga úmida e na salmoura durante o processamento.

Os teores de proteína solúvel na salmoura (Figura 8) com o desenvolvimento da salga úmida apresentaram tendência de aumento linear de acordo com a equação: proteína solúvel $=0,0116$ horas $+0,7814\left(R^{2}=0,8275\right)$. Para o tempo 0 do processamento, o valor inicial foi de $0,12 \mathrm{mg} / \mathrm{mL}$ atingindo 2,43 $\mathrm{mg} / \mathrm{mL}$ após 168 horas de salga. À medida que havia elevação no teor de proteína solúvel na salmoura havia uma perda de água nos filés devido à lixiviação das mesmas dos músculos (Tabela 1). Comportamento semelhante foi verificado por MACEDO-VIEGAS (2004) ao realizar a salga em salmoura da tilápia do Nilo, que obteve valores maiores $(3,37 \mathrm{mg} / \mathrm{mL})$ para o tempo de 156 horas de salga. Provavelmente, o aumento do teor das proteínas solúveis na salmoura seja devido à solubilização das proteínas miofibrilares que são solúveis em soluções salinas concentradas. Segundo SGARBIERI (1996) as proteínas perdem a água de hidratação quando presentes em solução salinas concentradas formando precipitados. A proteína da miofibrila é a que mais se altera por desnaturação sendo que esse processo ocorre por "salting-out". Em concentrações salinas acima de $15 \%$ ocorre uma redução da umidade no produto por desidratação 
(OGAWA \& MAIA, 1999). O inverso não acontece no final da salga devido à reabsorção de água e formação do complexo sal/proteína. Portanto, há uma mudança nas propriedades de absorção de água das proteínas musculares pelo emprego do sal.

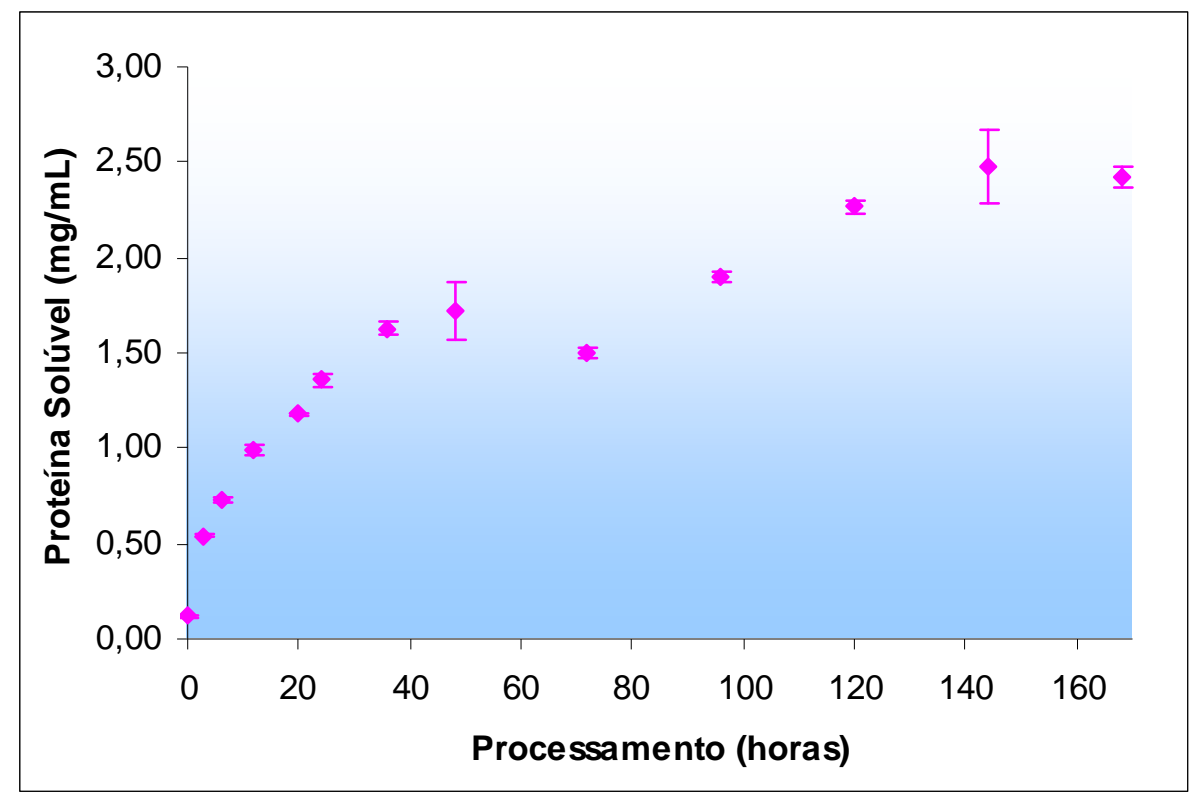

Figura 8 - Valores médios da proteína solúvel $(\mathrm{mg} / \mathrm{mL})$ e erro padrão dos filés de piracanjuba submetidos à salga úmida (SU) durante o processamento.

O pescado por ser um alimento rico em proteína, quando submetido a processos de salga, pode apresentar modificações na estrutura das moléculas de proteína. As proteínas presentes no músculo esquelético dos peixes podem ser divididas em fração contrátil (proteínas miofibrilares), uma fração solúvel (proteínas sarcoplasmáticas) e a não solúvel (proteínas estromáticas). Nas proteínas miofibrilares, por sua vez, estão compreendidas as proteínas contráteis, actina e miosina (75-80\%) e reguladoras (20\%). A conformação da proteína, ligada à sua estrutura secundária, terciária e quaternária, é lábil. Por isso, o tratamento com soluções salinas concentradas pode modificar essas estruturas. CHEFTEL \& CUQ (1984) definem como desnaturação qualquer modificação que ocorra na conformação (secundária, terciária e quaternária), sem que as ligações peptídicas sejam rompidas (estrutura primária). A desnaturação pode acontecer por meio de 
agentes físicos (calor, frio, tratamentos mecânicos, etc) e/ou agentes químicos (ácidos, bases, metais, solventes orgânicos, etc). Ainda, a desnaturação pode ser considerada como uma transição irreversível que inclui o calor endotérmico de desnaturação e, uma forma de quantificá-lo seria mediante o uso do calorímetro diferencial de varredura (DSC) (MEDINA-VIVANCO, 2003).

A finalidade principal da salga de filé de peixe, seca ou úmida, é o aumento da conservação do produto devido ao abaixamento de sua atividade de água, conseqüência da diminuição da umidade e aumento da concentração de sólidos solúveis (sal) no músculo. Normalmente, esses fenômenos físicos podem provocar alterações físico-químicas na estrutura do músculo, mais especificamente nas proteínas miofibrilares. Tanto a desidratação quanto a presença de eletrólitos no músculo podem desestabilizar as proteínas e conseqüentemente, provocar desnaturação a frio, o que tem sérias repercussões sobre a qualidade do produto final, como por exemplo, na perda da capacidade de rehidratação.

O estado das proteínas do filé fresco, com teor inicial de sal de 3,5\%, pode ser estudado a partir do termograma obtido nas análises por calorimetria diferencial de varredura (DSC), apresentado na Figura 9. O aquecimento da amostra, durante as análises, provocou a desnaturação térmica das proteínas que estavam originalmente no estado nativo (não desnaturadas). A desnaturação dessas proteínas pode ser observada na forma de picos invertidos indicando a ocorrência de fluxo endotérmico de calor. Dessa forma, a temperatura onde ocorreu o pico foi considerada como a temperatura de desnaturação $(\mathrm{Td})$ e a área sobre o pico endotérmico, corresponde à entalpia de desnaturação $(\Delta \mathrm{Hd})$, ou seja, a energia necessária à desnaturação.

Mais especificamente no caso do filé in natura, pôde-se observar a ocorrência de duas endotermas bem visíveis e uma inflexão ("shoulder") entre essas duas endotermas (Figura 9). Resultados similares foram obtidos por vários autores ao estudarem as proteínas miofibrilares de músculo in natura de diferentes espécies animais (WRIGHT et al., 1977; PARK \& LANIER, 1989; MA \& HARWALKAR, 1991; MONTERREY-QUINTERO \& SOBRAL, 2000; MEDINAVIVANCO, 2003; FURUKAWA et al., 2004). A primeira endoterma, isto é, aquela 
observada na mais baixa temperatura, está associada à desnaturação da miosina, apresentando uma $\mathrm{Td}$ de $49,7^{\circ} \mathrm{C}$ (Tabela 2 ). A segunda endoterma é associada à actina, e apresentou valor de $\mathrm{Td}$ de $78,8^{\circ} \mathrm{C}$. O resultado de $\mathrm{Td}$ da miosina foi inferior aos valores obtidos por MONTERREY-QUINTERO \& SOBRAL (2000), que encontraram $\mathrm{Td}=54,4 \pm 0,2^{\circ} \mathrm{C}$; PARK \& LANIER (1989) que obtiveram Td $=58,7$ $\pm 0,5^{\circ} \mathrm{C}$, e MEDINA-VIVANCO (2003), cuja $\mathrm{Td}$ foi $54,79 \pm 0,22^{\circ} \mathrm{C}$. Por outro lado, no caso da actina, os valores de Td determinados neste trabalho, situaram-se um pouco acima dos obtidos pelos referidos pesquisadores, que determinaram valores de $75,90 \pm 0,2^{\circ} \mathrm{C}, 74^{\circ} \mathrm{C}$ e $75,19 \pm 0,11^{\circ} \mathrm{C}$, respectivamente. Muito provavelmente, essas diferenças podem ser explicadas pelo fato daqueles autores terem analisados músculo de tilápia do Nilo. Infelizmente, não se encontraram resultados de calorimetria diferencial de varredura de filés de piracanjuba.

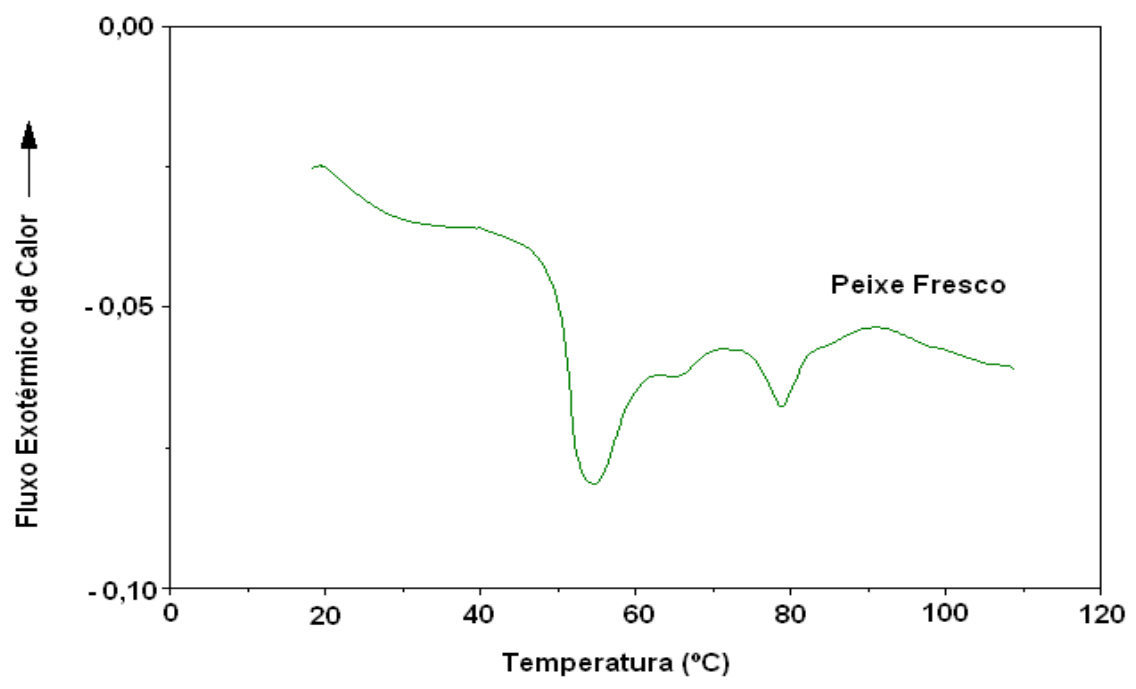

Figura 9 - Termograma de músculo fresco de piracanjuba. 
Tabela 2 - Valores médios dos resultados da análise por calorimetria diferencial de varredura dos filés de piracanjuba para o peixe fresco e submetidos à salga úmida (SU) e salga seca (SS) durante o processamento $(6,12$ e 168 horas).

\begin{tabular}{|c|c|c|c|c|c|c|c|c|}
\hline \multicolumn{2}{|c|}{ Amostra } & \multirow[t]{2}{*}{ Umidade (\%) ${ }^{1}$} & \multirow[t]{2}{*}{$\Delta \mathrm{Hd}(\mathrm{J} / \mathrm{g})^{2}$} & \multirow[t]{2}{*}{$\Delta \mathrm{Hd}(\mathrm{J} / \mathrm{g})^{3}$} & \multicolumn{4}{|c|}{ Temperatura de desnaturação } \\
\hline & & & & & Onset & Actina & Sarcoplasmáticas & Miosina \\
\hline \multicolumn{2}{|c|}{ Peixe fresco } & 78,6 & 3,86 & 14,17 & 49,67 & 54,76 & 65,41 & 78,84 \\
\hline \multicolumn{9}{|c|}{ Processamento } \\
\hline \multirow{2}{*}{6 horas } & SU & 69,1 & 2,56 & 8,28 & 62,28 & - & 62,52 & - \\
\hline & SS & 69,3 & 1,71 & 5,55 & 41,55 & - & 58,44 & - \\
\hline \multirow{2}{*}{12 horas } & SU & 54,9 & 4,96 & 10,99 & 41,33 & - & 64,71 & - \\
\hline & SS & 64,6 & 1,99 & 5,62 & 36,61 & - & 62,48 & - \\
\hline \multirow{2}{*}{168 horas } & SU & 59,3 & 0,31 & 0,75 & 30,73 & 40,77 & - & - \\
\hline & SS & 59,3 & 1,00 & 2,45 & 29,57 & 39,90 & - & - \\
\hline
\end{tabular}

1 - teor de umidade; 2 - entalpia de desnaturação da amostra úmida; 3 - entalpia de desnaturação da amostra seca 
Segundo WRIGHT et al. (1977), a inflexão intermediária às duas endotermas (Figura 9), pode estar associada à desnaturação das proteínas sarcoplasmáticas. Nesse caso, a temperatura de desnaturação foi calculada como $65,4^{\circ} \mathrm{C}$ (Tabela 2). Vários trabalhos que demonstraram resultados semelhantes a estes podem ser encontrados na literatura (WRIGHT et al., 1977; PARK \& LANIER, 1989; SOBRAL et al., 1998; MONTERREY-QUINTERO \& SOBRAL, 2000). A temperatura de desnaturação das proteínas sarcoplasmáticas dos filés de piracanjuba in natura, $65,4^{\circ} \mathrm{C}$ foi maior que o valor de $41,1^{\circ} \mathrm{C}$ obtido por HASTINGS et al. (1985), para músculo intacto de tilápia do Nilo.

Após 6 horas de salga, os filés de piracanjuba atingiram um teor de sal de $16,2 \%$ e $16,15 \%$, para a salga seca e úmida, respectivamente (Tabela 1). Essas concentrações de sal provocaram importantes alterações no perfil das curvas do DSC devido à alteração da estabilidade térmica das proteínas (Figura 10). É nítido o desaparecimento dos picos endotérmicos relativos à miosina e actina, tanto na salga seca quanto na úmida. Possivelmente, em função disso, a desnaturação das proteínas sarcoplasmáticas tornou-se mais evidente, agora na forma de um pico endotérmico, com valores de $\mathrm{Td}$ de $62,52^{\circ} \mathrm{C}$ e $58,44^{\circ} \mathrm{C}$, para salgas seca e úmida, respectivamente (Tabela 2 ). Comportamentos similares foram observados nas análises dos filés após 12 horas de salga, cujos teores de sal foram de 18,2\% e 17,49\% (Tabela 1), para salga seca e úmida, respectivamente (Figura 11). Nesse caso, os valores de $\mathrm{Td}$ foram $64,71^{\circ} \mathrm{C}$ para a salga seca e de $62,48^{\circ} \mathrm{C}$ (Tabela 2 ), para a úmida. 


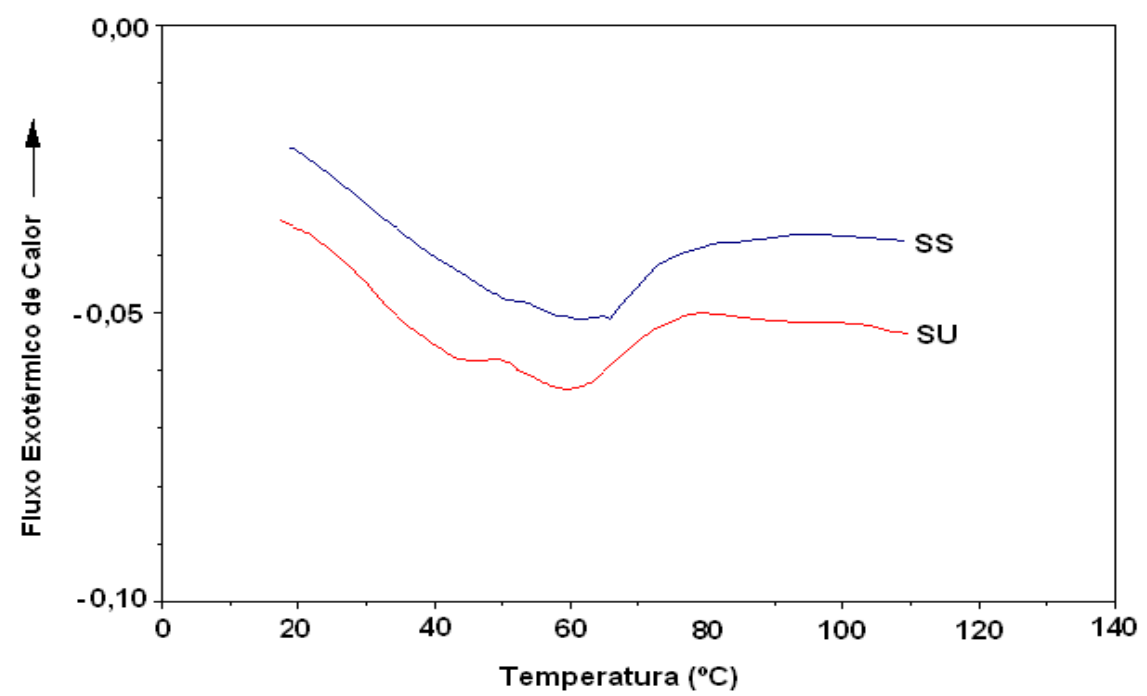

Figura 10 - Termograma de músculo de piracanjuba submetido à salga seca (SS) e úmida (SU) 6 horas após o início do processamento.

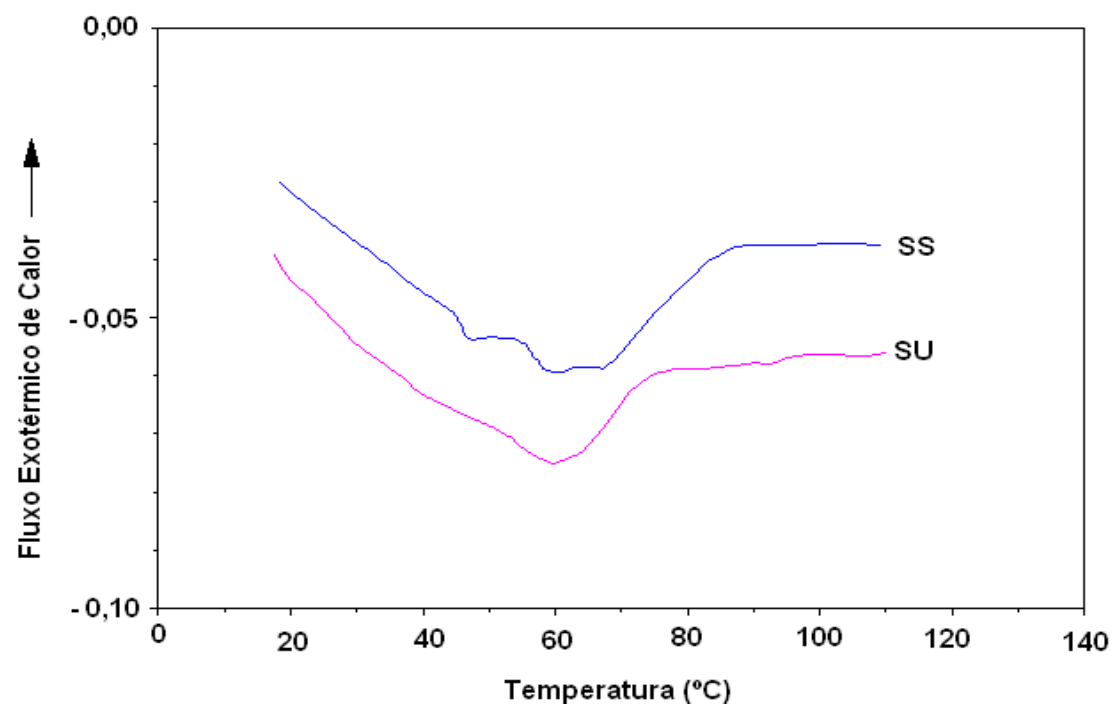

Figura 11 - Termograma de músculo de piracanjuba submetido à salga seca (SS) e úmida (SU) 12 horas após o início do processamento.

No máximo tempo de salga, 168 horas, os teores de cloreto de sódio nos filés de piracanjuba foram $21,08 \%$ e $23,86 \%$ para as salgas seca e úmida, nessa ordem (Tabela 1). Esse incremento de sal nos filés também provocou alterações 
importantes no perfil das curvas obtidas no DSC (Figura 12). Observou-se que ocorreu desnaturação fria de praticamente todas as frações de proteínas, verificando-se um pequeno pico em temperaturas muito baixas, a $40,8^{\circ} \mathrm{C}$ e $39,9^{\circ} \mathrm{C}$ para as salgas seca e úmida, respectivamente, sem, contudo ser possível associálas a uma dada fração de proteínas do músculo.

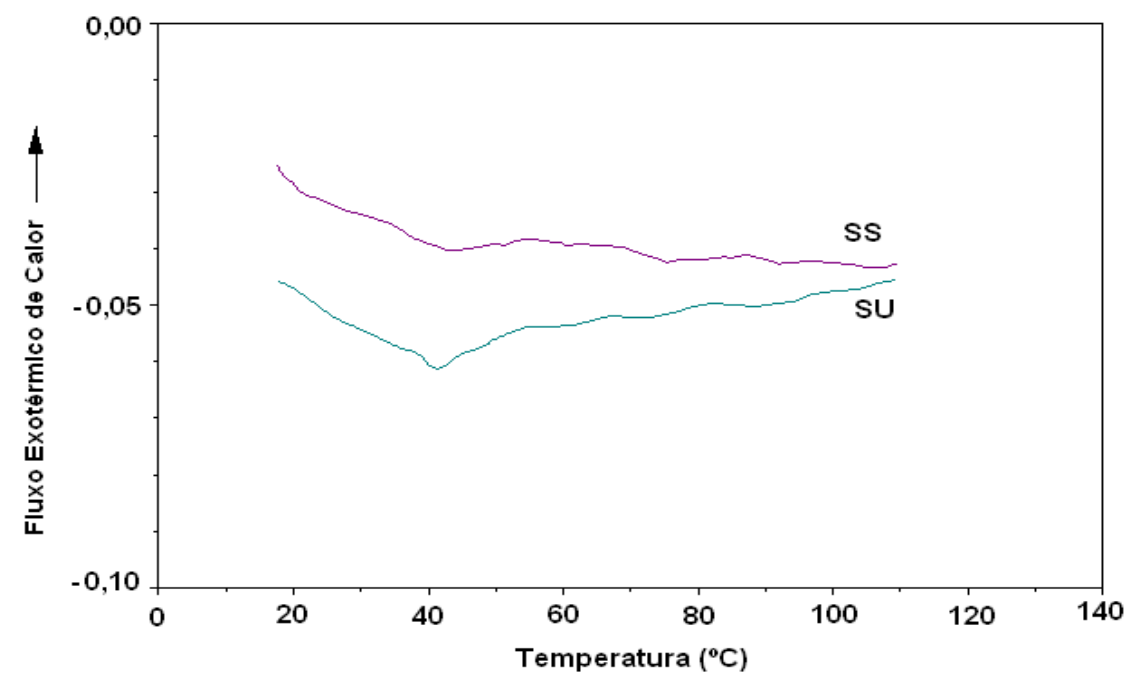

Figura 12. Termograma de músculo de piracanjuba submetido à salga seca (SS) e úmida (SU) 168 horas após o início do processamento.

De acordo com PARK \& LANIER (1989) pode haver uma diminuição da estabilidade térmica implicando na redução da temperatura de desnaturação e/ou na própria desnaturação dessas proteínas. Dessa forma, pode-se observar que as moléculas de sal nos filés desestabilizaram as frações miosina e actina, provocando o completo desaparecimento dessas proteínas na forma nativa, e permitindo assim, uma melhor visibilidade da desnaturação das proteínas sarcoplasmáticas. Por esse lado, percebe-se que o processo de salga seca alterou mais drasticamente a estabilidade dessas proteínas, que a salga úmida, proporcionando, portanto, menores valores de Td.

Além disso, pode-se observar na Tabela 1, que devido ao aumento do conteúdo de cloreto de sódio nas amostras, ocorreu redução das áreas dos picos, isto é, as entalpias de desnaturação diminuíram (PARK \& LANIER, 1989). Apesar da dispersão dos dados, pode-se sugerir que a salga seca provocou mais 
desnaturação à frio que a salga úmida, isto é, após esses processos, restava menos proteínas na forma nativa nos músculos. MEDINA-VIVANCO (2003) também verificou o desaparecimento da endoterma da miosina em amostras de filé de tilápia com $11,4 \% \mathrm{NaCl}$.

Os valores da entalpia de desnaturação das proteínas dos filés frescos de piracanjuba, que foram de cerca de $14 \mathrm{~J} / \mathrm{g}$ de amostra, foi menor que o obtido por FURUKAWA et al. (2004) com carne fresca de coelho ( $\Delta \mathrm{Hd}=17,6 \mathrm{~J} / \mathrm{g})$. Porém, PAREDI et al. (1994) estudaram este mesmo parâmetro para um tipo de ostra em função da força iônica de uma solução adicionada, e também observaram uma contínua redução da entalpia desnaturação.

A rancidez oxidativa dos lipídeos nas matérias primas empregadas no processamento do pescado salgado é uma das causas mais comuns de deterioração contribuindo para o desenvolvimento de um sabor e odor característico de ranço, bem como a formação de metabólitos tóxicos (ALOR, 1994). A oxidação lipídica pode ocorrer nos diferentes processos de salga tanto quanto no armazenamento.

Os valores médios de TBARS (expressos como mg de malonaldeído/kg) estão apresentados na Figura 13. A análise estatística permitiu a observação de diferença significativa e interação $(p<0,05)$ entre os tratamentos (salga seca e úmida) e entre o tempo de processamento (horas). O desdobramento das interações permitiu a identificação de diferença significativa entre os tratamentos nos tempos relativos às $3,12,24,36,96,144$ e 168 horas de salga; porém, às 3 e 12 horas de processamento a salga úmida apresentou valores de TBARS superiores aos da salga seca e, nas demais horas, a salga seca apresentou valores médios maiores.

Esses resultados foram inferiores aos obtidos por BOERI et al. (1982) para a merluza salgada. Valores mínimos de 4,0 mg de malonaldeído/kg foram encontrados por BERAQUET et al. (1983), quando trabalharam com a salga da cavalinha, sendo superiores aos teores verificados neste trabalho, tanto para a salga seca quanto para a úmida dos filés de piracanjuba. 


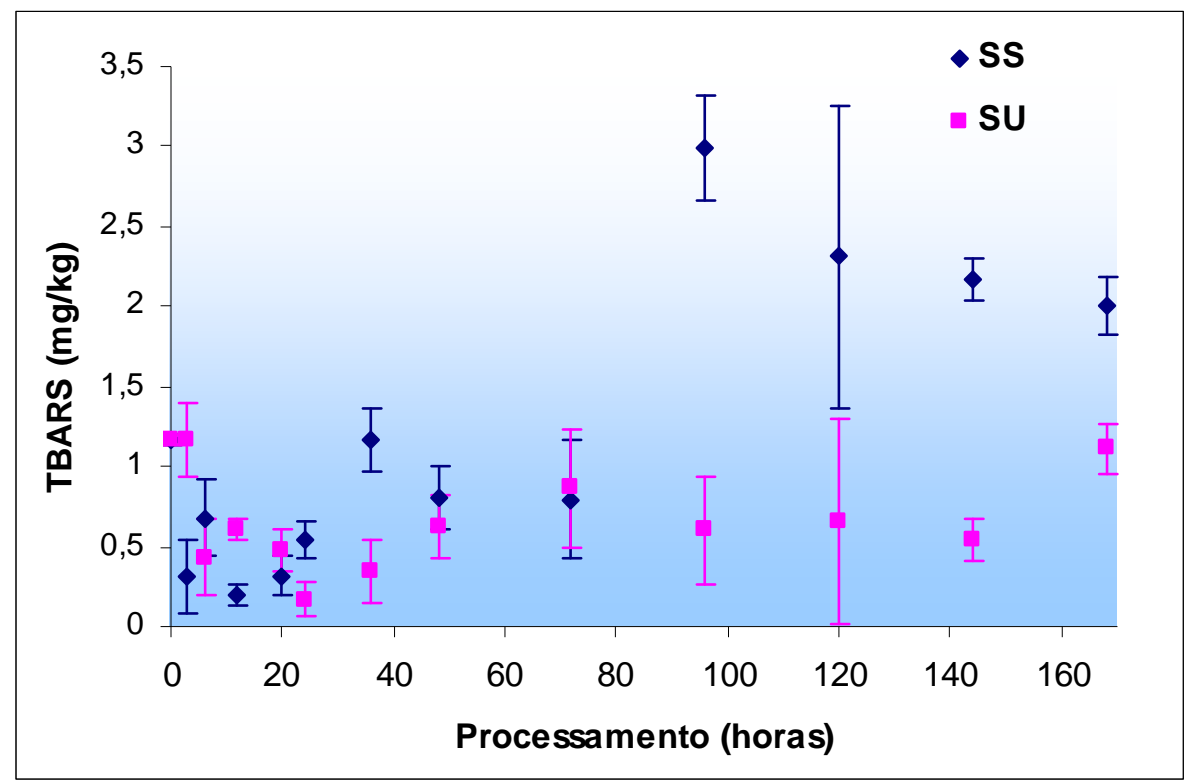

Figura 13 - Valores médios de TBARS (mg de malonaldeído/kg) e erro padrão dos filés de piracanjuba submetidos à salga seca (SS) e úmida (SU) durante o processamento.

A salga seca apresentou o valor máximo de TBARS de 2,99 mg de malonaldeído/kg com 96 horas de salga, enquanto que a úmida teve seu pico de 1,11, após 168 horas de salga. Os valores de malonaldeído no músculo da piracanjuba para a salga seca foram praticamente maiores do que para a salga úmida em quase todo o período de processamento. Isto pode ser devido à exposição do produto em relação ao oxigênio do ar.

MACEDO-VIEGAS (2004) relata valores de $0,5 \mathrm{mg}$ de malonaldeído/kg para o TBARS da salga em salmoura, no início do processamento de salga para a tilápia do Nilo, sendo que para a salga seca atingiram teores de 3,29.

Provavelmente, os baixos teores de TBARS verificados neste experimento ( 0,20 a 2,99, para a salga seca e 0,17 a 1,11 mg de malonaldeído/kg, para a úmida) podem ter sido decorrentes do baixo teor de lipídeos presentes no músculo da piracanjuba (peixe fresco - 0,88\% de gordura), classificada como peixe com baixo teor de gorduras, segundo STANBY (1965), citado por CONTRERASGUZMÁN (1994), que estabelece valores menores que 5\% de gordura para essa categoria. 
KELLEHER et al. (1994) citam que valores de TBARS de 0,9 a 1,5 mg de malonaldeído/kg são acompanhados de odor desagradável, mas odores de rancidez ocorrem quando valores de TBARS são superiores a $1,5 \mathrm{mg}$ de malonaldeído/kg. Embora os valores obtidos de TBARS para os filés de piracanjuba salgados, tenham sido superiores aos citados pelos autores, não foram verificados odores desagradáveis, para nenhuma das salgas durante 0 processamento.

A atividade de água é uma análise extremamente útil para se verificar a conservação dos produtos curados e está relacionada diretamente com a água disponível para o crescimento de microrganismos.

Os valores médios de $A_{a}$ estão apresentados na Figura 14. A análise estatística permitiu a observação de diferença significativa e interação $(p<0,05)$ entre os tratamentos (salga seca e úmida) e entre o tempo de processamento (horas). No desdobramento das interações identificou-se diferença significativa $(p<0,05)$ entre os valores médios dos tratamentos, a partir das 36 horas de processamento, sendo que a salga úmida apresentou valores de $A_{a}$ superiores aos da seca. A salga úmida apresentou valores médios maiores que o da salga seca para a atividade da água dos filés da piracanjuba em quase todos os tempos do processamento exceto para 3 e 20 horas após a salga, cujos valores foram de 0,90 e 0,84 , respectivamente.

A atividade de água para o peixe fresco foi de 0,99 (TO) atingindo valores de 0,81 para a salga úmida e de 0,74 para a seca, para o tempo de 168 horas de processamento. Para a salga seca e úmida houve tendência de estabilização quando os valores estiveram compreendidos entre 0,70 e 0,74 e 0,80 e 0,82 , respectivamente. A redução na $A_{a}$ está diretamente relacionada com conservação e estabilidade do produto, sendo um fator utilizado para calcular a influência da água nos alimentos sobre as alterações microbianas. A presença da água é uma condição essencial para o desenvolvimento de microrganismos (OGAWA \& MAIA, 1999). MORAIS et al. (1995) encontraram valores de $A_{a}$ variando de $<0,60$ a 0,78 para os blocos salgados, prensados e secos, com $20 \%$ de sal, obtidos da mistura de diferentes espécies de peixes capturados com o camarão sete barbas. 


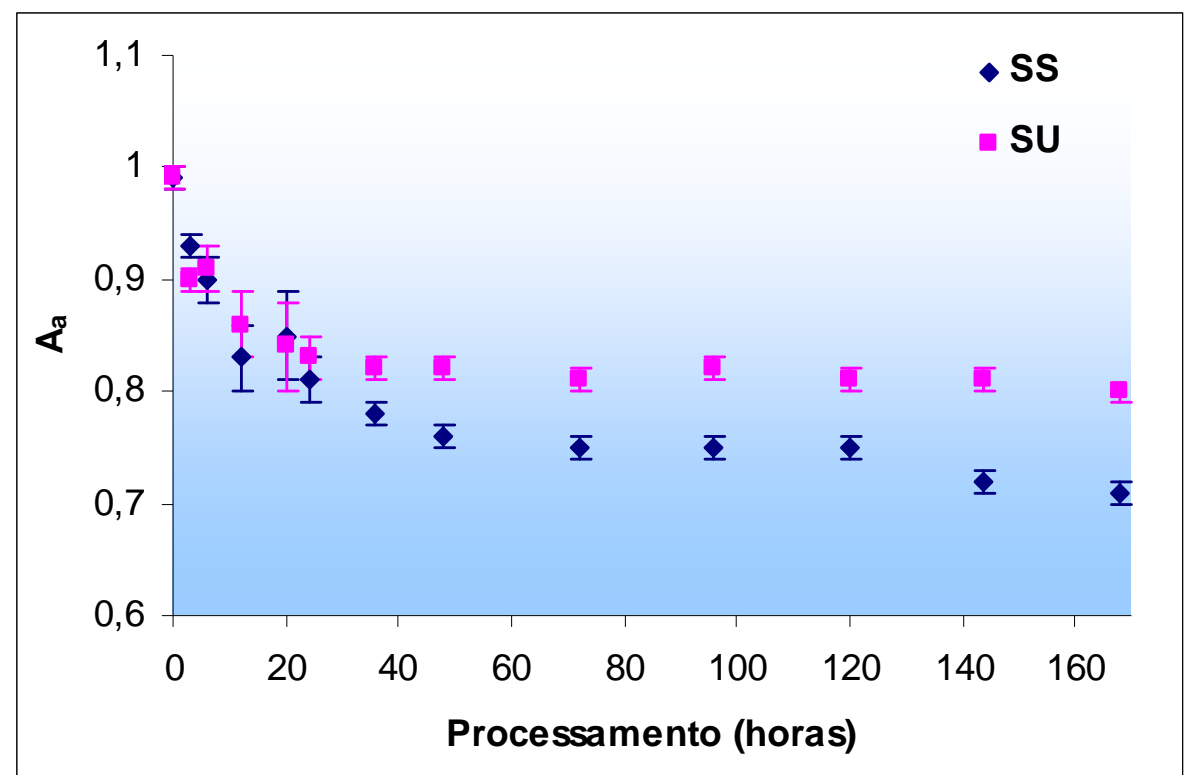

Figura 14 - Valores médios da atividade da água $\left(A_{a}\right)$ e erro padrão dos filés de piracanjuba submetidos à salga seca (SS) e úmida (SU) durante o processamento.

Os valores experimentais para as duas salgas foram praticamente idênticos no início do processamento, porém diferenciando-se a partir de 36 horas de ensaio, sendo os valores da salga úmida superiores aos da seca. Ao término da etapa de processamento (168 horas de salga), os resultados de $A_{a}$ foram 0,81 e 0,74 , nessa ordem, para a salga em salmoura saturada e seca. Esse mesmo comportamento foi verificado por SABADINI et al. (2001) para $A_{a}$, embora seus estudos tenham sido realizados com a carne de charque.

\subsection{Armazenamento}

Após o final do processamento, para ambas as salgas, os filés de piracanjuba foram colocados em estufa por 48 horas $\left(40^{\circ} \mathrm{C}\right)$, com a finalidade de acelerar o processo de retirada de água e assegurar a estabilidade do produto na estocagem. O armazenamento dos filés de piracanjuba foi monitorado para as duas salgas (úmida e seca) pelo período de 45 dias, por meio de uma série de análises, descritas a seguir, visando garantir a qualidade do produto final. Nas 
Figuras 15 e 16 visualizam-se o início (T0) e 30 dias do armazenamento para as salgas úmida e seca.
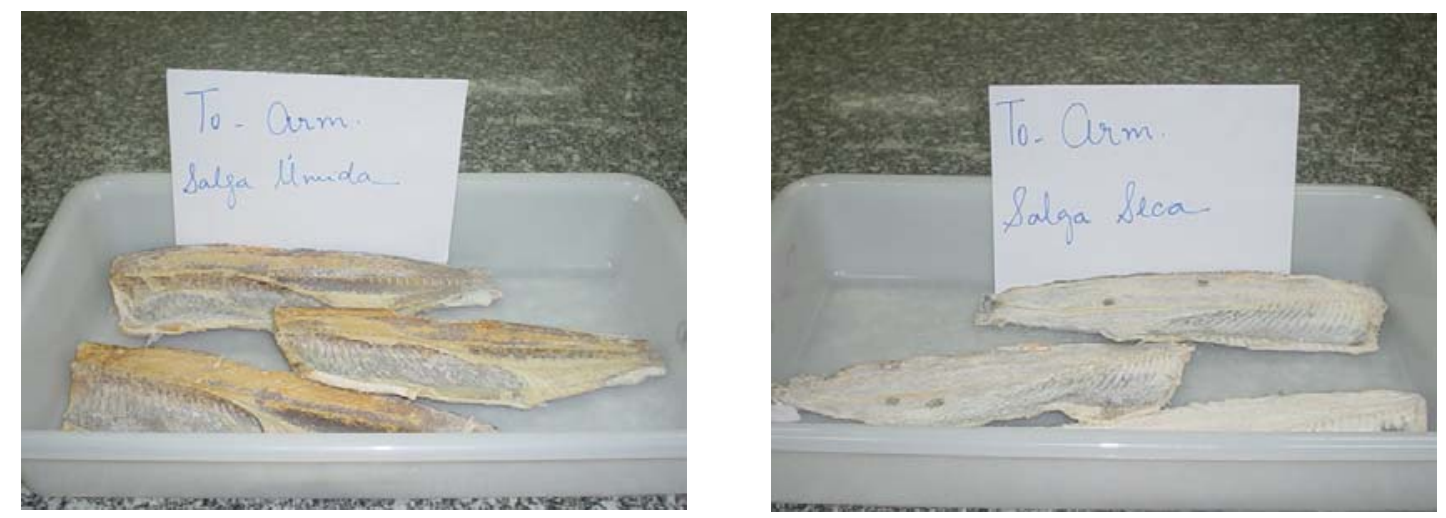

Figura 15 - Filés de piracanjuba submetidos à salga úmida e seca no início do armazenamento (T0)
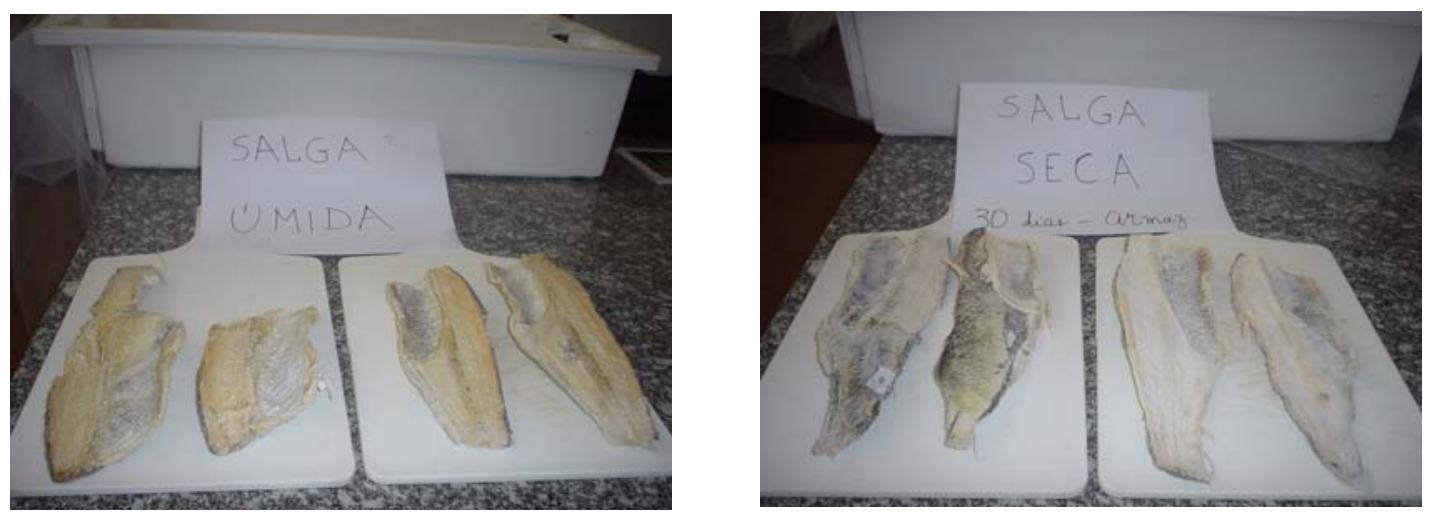

Figura 16 - Filés de piracanjuba submetidos à salga úmida e seca aos 30 dias de armazenamento.

$\mathrm{Na}$ Tabela 3 estão dispostos os resultados dos valores médios da composição centesimal (umidade, proteína bruta, extrato etéreo e matéria mineral) e erro padrão dos filés de piracanjuba para o peixe fresco e submetidos a salga úmida e seca durante o armazenamento. 
Tabela 3 - Valores médios da composição centesimal (\%) e erro padrão (ep) dos filés de piracanjuba para o peixe fresco e submetidos à salga úmida (SU) e seca (SS) durante o armazenamento.

\begin{tabular}{|c|c|c|c|c|c|c|c|c|c|}
\hline \multirow[b]{2}{*}{$\begin{array}{c}\text { Componentes } \\
\text { (\%) }\end{array}$} & & \multicolumn{2}{|c|}{ Umidade } & \multicolumn{2}{|c|}{$\mathrm{PB}^{1}$} & \multicolumn{2}{|c|}{$\mathrm{EE}^{2}$} & \multicolumn{2}{|c|}{$\mathrm{MM}^{3}$} \\
\hline & & Média* & ep & Média & ep & Média & ep & Média & ep \\
\hline Peixe fresco & & 77,15 & 0,76 & 19,04 & 0,40 & 0,88 & 0,02 & 1,14 & 0,08 \\
\hline \multirow{2}{*}{\multicolumn{10}{|c|}{$\begin{array}{l}\text { Armazenamento } \\
\text { (dias) }\end{array}$}} \\
\hline & & & & & & & & & \\
\hline \multirow{4}{*}{0} & SU & $47,38^{\mathrm{a}}$ & 1,83 & $25,30^{b}$ & 1,16 & 4,68 & 0,76 & $20,90^{\mathrm{a}}$ & 1,21 \\
\hline & SS & $37,20^{b}$ & 1,83 & $34,36^{a}$ & 1,16 & 5,97 & 0,76 & $20,91^{a}$ & 1,21 \\
\hline & Total & 42,29 & 1,29 & 29,83 & 0,82 & 5,32 & 0,54 & 20,90 & 0,86 \\
\hline & SU & $31,40^{\mathrm{a}}$ & 4,03 & $34,02^{b}$ & 1,99 & 6,34 & 0,98 & $25,96^{\mathrm{a}}$ & 1,80 \\
\hline \multirow[t]{3}{*}{30} & SS & $28,70^{a}$ & 4,03 & $40,52^{\mathrm{a}}$ & 1,99 & 6,74 & 0,98 & $21,56^{a}$ & 1,80 \\
\hline & Total & 30,05 & 2,85 & 37,27 & 1,41 & 6,54 & 0,69 & 23,76 & 1,27 \\
\hline & su & $16,63^{\mathrm{a}}$ & 2,14 & $44,77^{\mathrm{a}}$ & 2,12 & 5,98 & 1,15 & $27,17^{\mathrm{a}}$ & 3,33 \\
\hline \multirow[t]{2}{*}{45} & ss & $22,66^{\mathrm{b}}$ & 2,14 & $44,55^{a}$ & 2,12 & 7,39 & 1,15 & $16,39^{b}$ & 3,33 \\
\hline & Total & 19,64 & 1,52 & 44,66 & 1,50 & 6,68 & 0,81 & 21,78 & 2,35 \\
\hline
\end{tabular}

${ }^{1}$ Proteína bruta; ${ }^{2}$ Extrato etéreo; ${ }^{3}$ Matéria mineral.

*Médias na mesma coluna, por dia de armazenamento, seguidas por letras diferentes, diferem entre si pelo teste t-Student $(p<0,05)$.

A análise estatística dos valores médios da umidade permite-nos observar que houve interação significativa $(p<0,05)$ entre os tratamentos (salga úmida e seca) e os dias de armazenamento. De maneira geral, os valores médios de 
umidade da salga úmida ( 0 e 45 dias) foram superiores $(p<0,05)$ aos da salga seca, com exceção do período de 30 dias de armazenamento onde não foi observada diferença significativa. Pôde-se ainda verificar tendência quadrática de decréscimo da umidade em função do período de estocagem para a salga úmida (\%umidade $=47,65-$ 0,1054 dias - 0,01295 dias²) e linear para a seca (\%umidade $=38,54-0,3344$ dias). No estudo de correlação entre as medidas, observou-se correlação negativa $(p<0,05)$ entre umidade e proteína bruta $(r=-0,66)$ e entre a matéria mineral $(r=-0,70)$.

Os dois métodos de salga empregados neste estudo com a piracanjuba, são considerados métodos de cura forte ou pesada (heavy ou hard cure), nos quais utilizam-se concentrações elevadas de sal. Em produtos assim elaborados, o teor de umidade final após a secagem, varia entre 10 a 30\% e o conteúdo de sal, entre 25 a 35\% (BURGESS et al., 1967). Neste trabalho, foram observados valores mais elevados para os filés de piracanjuba no término do processo de salga e secagem (37 a 47\%), provavelmente devido a etapa de secagem na qual foram utilizadas temperaturas amenas $\left(45^{\circ} \mathrm{C}\right)$, por 48 horas, ocorrendo, portanto, menor perda de água. MACEDO-VIEGAS (2004) observou para filés salgados de tilápia do Nilo, 33,875 de umidade após secagem e MACHADO (1984) encontrou 355 para filés de pargo salgados e secos. A faixa dos teores de umidade citada por BURGESS et al. (1967), de 10 a 30\% só foi alcançada neste experimento após 30 dias de armazenamento tanto para a salga seca como para a úmida.

Com relação aos valores médios de proteína bruta (\%), observa-se interação significativa $(p<0,05)$ sendo que de maneira geral os valores médios de proteína bruta na salga seca foram superiores aos da salga úmida aos 0 e 30 dias de armazenamento. Porém, aos 45 dias não foi observada diferença significativa $(p>0,05)$ entre as médias dos tratamentos.

Para o extrato etéreo (\%) os valores médios obtidos não apresentaram diferença significativa entre os tratamentos, nem tampouco interação significativa $(p>0,05)$ entre os tratamentos e o período de armazenamento. Porém, nesse período, houve um acréscimo linear nos teores de EE, representado pela equação: \%EE = 5,3871 + 0,0317 dias. 
Quanto aos valores médios de matéria mineral (\%), foram encontradas diferenças significativas entre os tratamentos e interação $(p<0,05)$, exceto para o dia 0 de armazenamento não foi observada diferença significativa $(p>0,05)$. Não foram observadas diferenças entre os tratamentos para 0 e 30 dias de armazenamento, mas aos 45 dias, os valores de MM foram superiores para a salga em salmoura saturada, quando comparados aos da salga seca.

Pôde-se observar para todas as variáveis estudadas que, houve um aumento dos teores de proteína bruta, extrato etéreo e matéria mineral, em função da diminuição da umidade no processo de salga úmida e seca.

Para a proteína bruta presente no filé fresco de piracanjuba (Tabela 3) foram encontrados teores de 19,04\% e após a secagem, para a salga úmida e seca, respectivamente, de $25,30 \%$ e $34,36 \%$, atingindo no final do armazenamento (45 dias) valores de $44,77 \%$ e $44,55 \%$. As proteínas dos pescados podem ser quebradas em compostos nitrogenados menores por proteólises, através da ação das enzimas presentes nos tecidos dos músculos dos peixes ou nos microrganismos. Esses compostos nitrogenados migram para a solução de salmoura saturada, durante o processo, e as frações de proteína que permanecem no músculo são decompostas em aminoácidos livres e peptídeos (ALM, 1965).

A porcentagem de extrato etéreo obtida no início do processo de salga foi de $0,88 \%$, sendo que a piracanjuba pode ser considerada um peixe magro, segundo STANBY (1965). Foram encontrados aumentos deste valor para 4,68\% (salga úmida) e de 5,97\% (salga seca) para a etapa considerada T0 do armazenamento. Segundo ALM (1965) o teor de lipídeos nos pescados pode melhorar a qualidade, bem como satisfazer as exigências dos consumidores de peixe salgado. Em certas regiões do Brasil, o peixe salgado, considerado ideal pelo consumidor local, é aquele que apresenta grau de rancidez elevado, com coloração amarelada, sabor acentuado e aroma característico (PINHEIRO, 1995).

O peixe fresco, no início do experimento, possuía um teor de matéria mineral (ou cinzas) de 1,14\%. Após a fase de processamento e secagem os valores foram de $20,90 \%$ e de $20,91 \%$ para a salga úmida e seca, 
respectivamente, passando a $27,17 \%$ e $16,39 \%$, aos 45 dias de armazenamento. A obtenção desses valores se deve à incorporação do sal pelo músculo do pescado durante os referidos processos, contribuindo para o aumento no teor de cinzas das amostras (OGAWA \& MAIA, 1999). O cloreto de sódio ( $\mathrm{NaCl}$ ) é o principal componente das cinzas e o que se encontra em maior quantidade na matéria mineral dos pescados salgados e secos (DYER et al., 1977; TAVARES, 1995; OETTERER et al., 2003). SALES et al. (1986) encontraram valores de $12,0 \%$ para as cinzas de tucunaré salgado e seco, após a salga e secagem do produto, sendo que os valores obtidos para as cinzas dos filés de piracanjuba salgada e seca foram superiores às verificadas por estes autores, em todas as fases do armazenamento.

Vários pesquisadores também obtiveram resultados semelhantes para a umidade, proteína bruta, extrato etéreo e matéria mineral, observando aumentos nos parâmetros citados após salga, secagem e armazenamento de diferentes tipos de peixes: ZAPATA et al. (1986), SALES et al. (1986), MORAIS et al. (1994), MEDINA-VIVANCO (2003), OETTERER et al. (2003), MACEDO-VIEGAS (2004), dentre outros.

Não foram encontrados dados na literatura para os minerais analisados neste estudo para os filés de piracanjuba e/ou pescados salgados e secos para que os resultados pudessem ser comparados. A maior parte das referências é feita para os minerais existentes nos pescados frescos ("in natura").

Os valores de minerais obtidos para o peixe fresco, neste estudo, foram de 0,021\% para o sódio, 0,14\% para o fósforo, 0,011\% para o magnésio, 0,073\% para o cálcio, 0,40\% para o potássio, 4,54 ppm para o zinco e 4,23 ppm para o ferro. Foram encontrados apenas traços dos minerais cobre e manganês. Esses dados estão de acordo com os obtidos por DYER et al. (1977), SIKORSKI et al. (1994) e CONTRERAS-GUZMÁN (1994).

Da mesma forma que se verificou um aumento nos teores dos nutrientes relativos à composição centesimal, em função da perda de umidade e desidratação pela ação do sal, alguns dos minerais estudados apresentaram elevação nos seus teores, em relação ao peixe fresco, após a secagem e a 
obtenção do produto final, como é o caso do fósforo, magnésio, cálcio, sódio, zinco e ferro.

Os valores médios dos teores dos minerais fósforo e magnésio podem ser visualizados na Tabela 4. Observou-se para o fósforo diferença significativa entre os tratamentos e entre os dias de armazenamento, porém não se observou interação $(p>0,05)$. Os valores médios dos teores de fósforo para salga úmida e seca foram, respectivamente, $0,21 \%$ e $0,39 \%$, sendo significativamente superiores para a salga seca. Para o magnésio, os valores médios encontrados permitiram a observação de diferença apenas entre os tratamentos sendo 0,04\% e 0,06\% para a salga úmida e seca, respectivamente.

Tabela 4 - Valores médios dos teores de fósforo e magnésio e erro padrão (ep) dos filés de piracanjuba submetidos à salga úmida e seca durante o armazenamento (dias).

\begin{tabular}{|c|c|c|c|c|c|c|c|c|c|c|c|c|}
\hline \multirow[b]{3}{*}{ Dias } & \multicolumn{6}{|c|}{ Fósforo (\%) } & \multicolumn{6}{|c|}{ Magnésio (\%) } \\
\hline & \multicolumn{2}{|c|}{$\begin{array}{l}\text { Salga } \\
\text { Úmida }\end{array}$} & \multicolumn{2}{|c|}{$\begin{array}{l}\text { Salga } \\
\text { Seca }\end{array}$} & \multicolumn{2}{|c|}{ Total } & \multicolumn{2}{|c|}{$\begin{array}{l}\text { Salga } \\
\text { Úmida }\end{array}$} & \multicolumn{2}{|c|}{$\begin{array}{l}\text { Salga } \\
\text { Seca }\end{array}$} & \multicolumn{2}{|c|}{ Total } \\
\hline & Média* & ep & Média & ep & Total & ep & Média & ep & Média & ep & Média & ep \\
\hline 0 & 0,14 & 0,03 & 0,39 & 0,03 & 0,26 & 0,02 & 0,02 & 0,01 & 0,06 & 0,01 & 0,04 & 0,01 \\
\hline 30 & 0,18 & 0,03 & 0,33 & 0,03 & 0,25 & 0,02 & 0,04 & 0,01 & 0,07 & 0,01 & 0,05 & 0,01 \\
\hline 45 & 0,33 & 0,05 & 0,45 & 0,05 & 0,39 & 0,03 & 0,05 & 0,01 & 0,07 & 0,01 & 0,06 & 0,01 \\
\hline Total & $0,21^{b}$ & 0,01 & $0,39^{a}$ & 0,01 & & & $0,04^{b}$ & 0,01 & $0,06^{a}$ & 0,01 & & \\
\hline
\end{tabular}

* Médias na mesma linha, por dia de armazenamento e por mineral, seguidas por letras diferentes, diferem entre si pelo teste t-Student $(p<0,05)$.

Os valores médios da porcentagem dos minerais cálcio e potássio com seus respectivos erros padrões estão apresentados na Tabela 5. Os valores 
médios do teor do mineral cálcio que não foram diferentes estatisticamente $(p>0,05)$ entre os tratamentos, nem entre os dias de armazenamento e também não se verificou interação entre eles. Tais resultados permitiram concluir que o tipo de salga e o tempo de armazenamento não afetaram os teores desse mineral nos filés de piracanjuba. Porém, na análise estatística do potássio foi observada uma diminuição quadrática desses valores, do tempo 0 para os 45 dias de armazenamento, para a salga seca segundo a equação: $\% \mathrm{~K}=0,84+0,023$ dias 0,0008 dias $^{2}$.

Tabela 5 - Valores médios dos teores de cálcio e potássio e erro padrão (ep) para os filés de piracanjuba submetidos à salga úmida e seca durante o armazenamento (dias).

\begin{tabular}{|c|c|c|c|c|c|c|c|c|c|c|c|c|}
\hline \multirow[b]{3}{*}{ Dias } & \multicolumn{6}{|c|}{ Cálcio (\%) } & \multicolumn{6}{|c|}{ Potássio (\%) } \\
\hline & \multicolumn{2}{|c|}{$\begin{array}{l}\text { Salga } \\
\text { Úmida }\end{array}$} & \multicolumn{2}{|c|}{$\begin{array}{l}\text { Salga } \\
\text { Seca }\end{array}$} & \multicolumn{2}{|c|}{ Total } & \multicolumn{2}{|c|}{$\begin{array}{l}\text { Salga } \\
\text { Úmida }\end{array}$} & \multicolumn{2}{|c|}{$\begin{array}{l}\text { Salga } \\
\text { Seca }\end{array}$} & \multicolumn{2}{|c|}{ Total } \\
\hline & Média* & ep & Média & ep & Média & ep & Média & ep & Média & ep & Total & ep \\
\hline 0 & 0,28 & 0,13 & 0,50 & 0,13 & 0,39 & 0,09 & $0,10^{b}$ & 0,05 & $0,84^{a}$ & 0,05 & 0,47 & 0,04 \\
\hline 30 & 0,39 & 0,08 & 0,37 & 0,08 & 0,38 & 0,06 & $0,11^{b}$ & 0,05 & $0,85^{a}$ & 0,05 & 0,48 & 0,03 \\
\hline 45 & 0,56 & 0,14 & 0,34 & 0,14 & 0,45 & 0,10 & $0,15^{b}$ & 0,02 & $0,33^{a}$ & 0,02 & 0,24 & 0,01 \\
\hline Total & 0,41 & 0,04 & 0,40 & 0,04 & & & $0,12^{b}$ & 0,03 & $0,67^{a}$ & 0,03 & & \\
\hline
\end{tabular}

\footnotetext{
* Médias na mesma linha, por dia de armazenamento e por mineral, seguidas por letras diferentes,
} diferem entre si pelo teste t-Student $(p<0,05)$.

DYER et al. (1977) citam que os valores de cálcio, muitas vezes, podem estar superestimados devido à inclusão de ossos intramusculares nas amostras, acarretando também o aumento nos teores de fósforo e de magnésio. Porém, quando não há inclusão de pedaços de ossos ou de conchas, os teores de cálcio 
em peixes são semelhantes aos verificados para outros tipos de carnes. Isso não foi verificado neste experimento.

Para o mineral sódio ( $\mathrm{Na})$, observou-se diferença significativa $(p<0,05)$ entre os tratamentos e entre os dias de armazenamento. As porcentagens médias de sódio encontradas na salga úmida (18,57\%, 17,83\% e 15,63\%) apresentaramse superiores às da salga seca $(15,77 \%, 15,23 \%$ e 14,14\%) durante todo 0 período de armazenamento (0, 30 e 45 dias, respectivamente). Pôde-se observar efeito linear de diminuição da porcentagem de $\mathrm{Na}$ em função do tempo, para ambos os tratamentos, de acordo com as equações apresentadas na Figura 17.

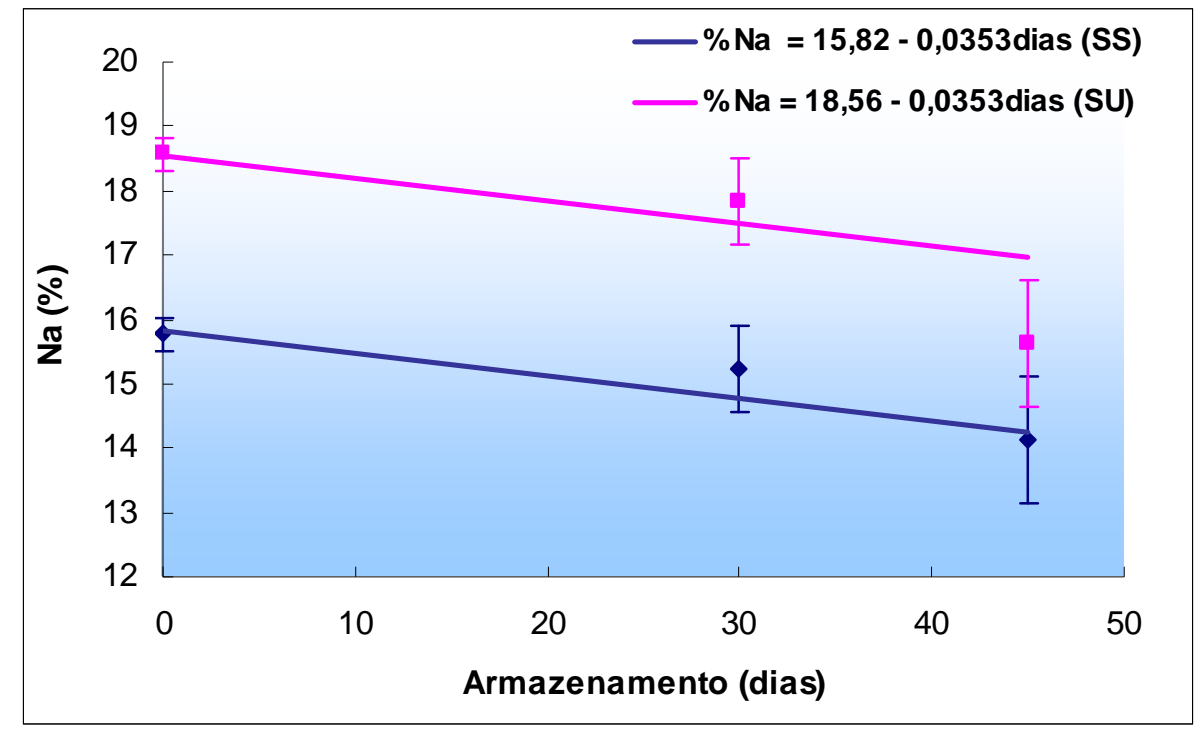

Figura 17 - Valores médios do teor de sódio (Na) e erro padrão dos filés de piracanjuba submetidos à salga seca (SS) e úmida (SU) durante o armazenamento.

A análise estatística dos valores médios dos teores de zinco permitiu a observação de interação significativa $(p<0,05)$ entre dias e entre tratamento e dias. Verificou-se que para as duas salgas houve um aumento quadrático em função do tempo de armazenamento, de acordo com as equações: \%Zn = 29,60 - 0,265 dias $+0,0129$ dias $^{2}$ e $\% Z n=32,717$ - 0,6248 dias $+0,0184$ dias $^{2}$, respectivamente, para a salga úmida e seca. Para o teor de ferro foram encontradas diferenças 
significativas $(p<0,05)$ apenas entre os dias, o que pode ser explicado pela equação: $\% \mathrm{Fe}=16,9083+0,5766$ dias $-0,01715$ dias $^{2}$.

Os valores médios dos teores dos microminerais zinco e ferro estão apresentados na Tabela 6.

Tabela 6 - Valores médios dos teores de zinco e ferro e erro padrão (ep) para os filés de piracanjuba submetidos à salga úmida e seca durante o armazenamento (dias).

\section{Zinco (ppm)}

\begin{tabular}{|c|c|c|c|c|c|c|c|c|c|c|c|c|}
\hline \multirow[b]{2}{*}{ Dias } & \multicolumn{2}{|c|}{$\begin{array}{l}\text { Salga } \\
\text { Úmida }\end{array}$} & \multicolumn{2}{|c|}{$\begin{array}{l}\text { Salga } \\
\text { Seca }\end{array}$} & \multicolumn{2}{|c|}{ Total } & \multicolumn{2}{|c|}{$\begin{array}{l}\text { Salga } \\
\text { Úmida }\end{array}$} & \multicolumn{2}{|c|}{$\begin{array}{l}\text { Salga } \\
\text { Seca }\end{array}$} & \multicolumn{2}{|c|}{ Total } \\
\hline & Média* & ep & Média & ep & Média & ep & Média & ep & Média & ep & Total & ep \\
\hline 0 & $29,60^{b}$ & 1,10 & $32,72^{\mathrm{a}}$ & 1,10 & 31,16 & 0,78 & 14,45 & 2,95 & 19,37 & 2,95 & 16,91 & 2,08 \\
\hline 30 & $33,22^{\mathrm{a}}$ & 0,93 & $30,55^{b}$ & 0,93 & 31,88 & 0,66 & 20,10 & 2,37 & 17,43 & 2,37 & 18,77 & 1,68 \\
\hline 45 & $43,70^{a}$ & 2,26 & $41,90^{\mathrm{a}}$ & 2,26 & 42,80 & 1,60 & 9,20 & 3,57 & 7,03 & 3,57 & 8,12 & 2,53 \\
\hline Total & $35,51^{a}$ & 0,99 & $35,05^{a}$ & 0,99 & & & $14,58^{a}$ & 1,31 & $14,61^{a}$ & 1,31 & & \\
\hline
\end{tabular}

* Médias na mesma linha, por dia de armazenamento e por mineral, seguidas por letras diferentes, diferem entre si pelo teste t-Student $(p<0,05)$.

Os microminerais cobre e manganês também foram analisados, sendo obtidos apenas traços dos mesmos, nas amostras dos filés de piracanjuba salgado e seco, para os tempos de 0, 30 e 45 dias de armazenamento.

LESSI (1995) recomenda o emprego de um sal de boa qualidade para o processamento de pescados, caso contrário o produto final terá seu valor nutricional diminuído. Desta forma, considera que o sal de boa qualidade deva possuir cerca de 99,0\% de cloreto de sódio, enquanto que o sal de qualidade inferior pode apresentar redução desses valores, e chegar a até $80,0 \%$ de cloreto 
de sódio. O sal comum pode apresentar impurezas de natureza química, como cálcio e magnésio na forma de sulfatos ou cloretos. Ainda, carbonato de sódio e traços de cobre e ferro podem estar presentes. Todas essas impurezas podem diminuir a velocidade de absorção do sal, na forma de cloreto de sódio, durante o processo de salga do pescado, enquanto que o cloreto de magnésio facilita a absorção da umidade do ar, criando condições para o crescimento e microrganismos, especialmente as bactérias do tipo halofílicas e fungos (Penicillium sp). Os teores de cálcio em até 0,3\% e os de magnésio até 0,5\%, no sal, dão origem a uma cura clara, enquanto que a ausência destes elementos pode originar um produto flexível e amarelado. Um sabor amargo no produto final pode ser verificado se os teores de cálcio e magnésio forem elevados. Outras impurezas como cobre e ferro podem acelerar a oxidação dos lipídeos no pescado salgado e seco (LESSI, 1995 ).

Observa-se interação significativa $(p<0,05)$ para os valores médios de cloreto (Figura 18) presentes nos filés salgados de piracanjuba. No desdobramento da interação constatou-se diferença significativa $(p<0,05)$ entre os valores médios dos tratamentos sendo que a salga úmida apresentou valores médios, em \%, de 23,69, 24,48, 23,37 e 20,74 e a salga seca, de 18,61, 15,97, 16,84 e 17,66 ambos aos 0, 15, 30 e 45 dias de armazenamento. Os valores médios de cloreto para a salga em salmoura saturada foram superiores aos obtidos para a salga seca aos 0, 15 e 30 dias. Pôde-se observar ainda, para a salga úmida, que a porcentagem de cloreto aumentou até $014^{\circ}$ dia de armazenamento e, em seguida, houve uma diminuição até 0 final do armazenamento (45 dias), de acordo com a equação: $\% \mathrm{Cl}=23,70+$ 0,1075 dias 0,00394 dias ${ }^{2}$. Um comportamento oposto foi verificado para a salga seca, havendo primeiro uma diminuição na porcentagem de cloreto, até o $21^{\circ}$ dia, com posterior aumento, de acordo com a equação: \%Cl = 18,56 - 0,22 dias + 0,00527 dias $^{2}$. 


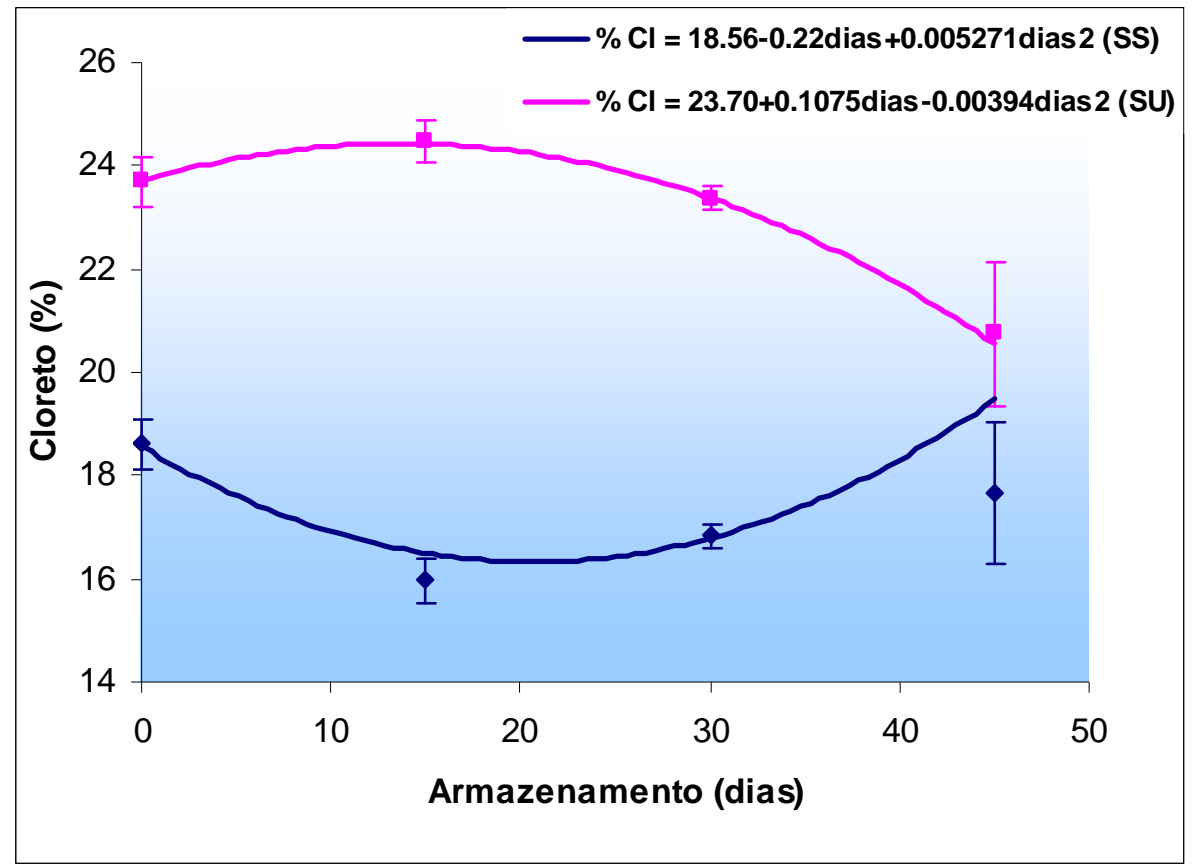

Figura 18 - Valores médios de cloreto (\%) e erro padrão dos filés de piracanjuba submetidos à salga seca (SS) e úmida (SU) durante o armazenamento.

O binômio teor de sal:conteúdo de umidade do produto, segundo PINHEIRO (1995), é um parâmetro importante que se refere ao estabelecimento de valores associados aos padrões de qualidade para produtos curados. MACEDO-VIEGAS (2004) observaram teores de cloreto ao redor de $23 \%$ nos filés salgados de tilápia do Nilo, armazenados por 45 dias, em temperatura ambiente.

A Tabela 7 apresenta as variações de umidade, porcentagem de sal e a relação cloreto/umidade para os filés de piracanjuba submetidos à salga úmida e seca, durante o armazenamento. Observa-se que a relação cloreto/umidade, preconizada por SALES et al. (1986), baseado em trabalho de FREITAS et al. (1981) como ideal, de 0,39 a 0,42, para uma boa conservação do pescado salgado e seco, já teria sido atingida no decorrer do processamento (48 e 72 horas, respectivamente, para a salga seca e úmida). Verifica-se que os valores da relação cloreto/umidade deste trabalho, na estocagem, situaram-se todos acima da referida faixa e também dos dados alcançados por SALES et al. (1986) cujos 
valores variaram de 0,23 a 0,34, para o tucunaré salgado e seco (Cichla ocellaris), armazenados por um período de 35 dias. Estes autores consideraram ideal uma relação de 0,34 para uma boa conservação do produto final. Não foram encontrados outros valores além destes comentados para comparar estes dados. Os valores encontrados para a relação cloreto/umidade, durante o armazenamento, estiveram sempre acima dos citados como ideal para ambas as salgas. No final dos 45 dias de armazenamento, a salga seca apresentou 0,78 para relação cloreto/umidade enquanto que valores de 1,25 foram obtidos para a úmida, demonstrando que a salga foi efetiva para a conservação do pescado.

Tabela 7 - Valores médios de umidade (\%), cloreto (\%) e relação cloreto/umidade dos filés de piracanjuba submetidos à salga úmida (SU) e seca (SS) durante o armazenamento (dias).

\begin{tabular}{ccccccc}
\hline & \multicolumn{2}{c}{ Umidade (\%) } & \multicolumn{2}{c}{ Cloreto (\%) } & \multicolumn{2}{c}{$\begin{array}{c}\text { Relação } \\
\text { cloreto/umidade }\end{array}$} \\
\cline { 2 - 8 } Dias & SU & SS & SU & SS & SU & SS \\
\hline \hline 0 & 47,38 & 37,20 & 23,69 & 18,61 & 0,50 & 0,50 \\
\hline 15 & 43.20 & 36,56 & 24,48 & 15,97 & 0,57 & 0,44 \\
\hline 30 & 31,40 & 28,70 & 23,37 & 16,84 & 0,74 & 0,59 \\
\hline 45 & 16,63 & 22,66 & 20,74 & 17,66 & 1,25 & 0,78 \\
\hline
\end{tabular}

Segundo SIKORSKI (1994) o NNP é indicado como índice de determinação do frescor, por ser a primeira fração a ser utilizada pelos microrganismos, servindo de fonte de energia para os mesmos. Uma possível explicação para essas variações seria a ocorrência simultânea da utilização de substâncias resultantes da atividade microbiana sobre os aminoácidos sulfurados, especialmente na forma livre como componentes do "pool" de NNP, causando sua redução e ao mesmo 
tempo, gerando e repondo muitos compostos constituintes, devido a reações autolíticas e atividade proteolítica dos microrganismos (MUJICA, 2000).

Os valores médios de nitrogênio não protéico (NNP) até 30 dias de armazenamento e seus respectivos erros padrões estão apresentados na Figura 19. A análise estatística dos valores médios permite a observação de interação significativa $(p<0,05)$ entre os tratamentos e os dias de armazenamento. No desdobramento da interação, observou-se que nos dois períodos de armazenamento houve diferença significativa entre os tratamentos, sendo que em ambos os casos a salga úmida mostrou-se mais eficiente $(127,87$ e $174,53 \mathrm{mg} / 100 \mathrm{~g})$, com valores de NNP inferiores aos da salga seca $(404,60 \mathrm{e}$ $386,37 \mathrm{mg} / 100 \mathrm{~g}$ ) aos 0 e 30 dias de armazenamento, respectivamente. Por outro lado, no estudo comparativo dos valores médios entre os dias de armazenamento pôde constatar-se diferença significativa $(p<0,05)$ apenas no tratamento de salga úmida, onde houve um aumento dos valores médios NNP de 0 para 30 dias.

CONTRERAS-GUZMÁN (2002) relata valores de NNP compreendidos entre 210 e 343mg/100g de músculo para vários peixes brasileiros de água doce.

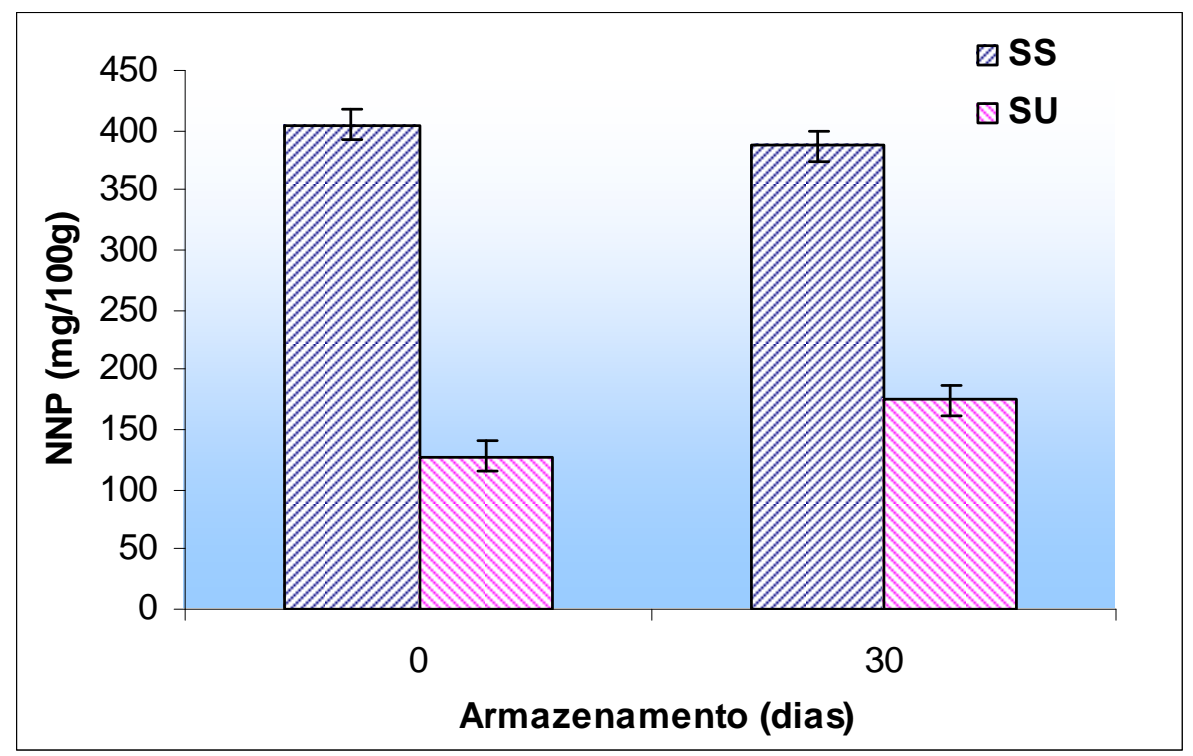

Figura 19 - Valores médios de nitrogênio não protéico (NNP) e erro padrão dos filés de piracanjuba submetidos à salga seca (SS) e úmida (SU) durante o armazenamento. 
SANNAVEERAPPA et al. (2004), ao estudarem a salga do "milkfish" (Chanos chanos), verificaram que a redução nos teores de NNP foi levemente superior para a salga úmida quando comparada à seca. Neste experimento com os filés de piracanjuba salgado foi observado comportamento inverso, pois os valores de NNP obtidos para a salga seca foram maiores que o da úmida.

No presente estudo com filés de piracanjuba, os teores mais baixos de NNP, após o processo de salga e secagem, sugerem que o método de salga úmida provocou o arraste dos componentes do NNP, favorecendo desta forma maior estabilidade do produto durante o armazenamento.

A determinação das N-BVT é mais um parâmetro empregado na avaliação do frescor dos produtos de pescados salgados e secos, porém é causa de muita controvérsia entre os pesquisadores, no tocante aos limites de aceitação do produto. O valor de $30 \mathrm{mgN} / 100 \mathrm{~g}$ tem-se mostrado compatível com outros parâmetros de avaliação, sendo que o Brasil e outros países o adotaram como limite máximo para comercialização (CONNELL, 1975; BERAQUET \& LINDO, 1985; KUAYE, 1982; BRASIL, 2002;).

Os valores médios para as bases nitrogenadas voláteis (N-BVT) estão apresentados na Figura 20 em função do período de armazenamento (0 e 30 dias). A análise estatística dos valores médios permite a observação de interação significativa $(p<0,05)$ entre os tratamentos e os dias de armazenamento. No desdobramento da interação, observou-se que nos dois períodos de armazenamento houve diferença significativa $(p<0,05)$ entre os tratamentos, sendo que em ambos os casos a salga úmida mostrou valores de N-BVT inferiores (1,49 e 4,74 mg/100g) aos da salga seca $(12,17$ e $12,62 \mathrm{mg} / 100 \mathrm{~g})$ para 0 e 30 dias de armazenamento, nessa ordem. No estudo comparativo dos valores médios entre os dias de armazenamento, pôde ser constatado diferença significativa apenas no tratamento de salga úmida onde houve um aumento dos valores médios de N-BVT de 0 para 30 dias. Vale ressaltar que no estudo da correlação entre NNP e N-BVT foi verificado baixa correlação e não significativa $(r=0,2847$; $p=0,46$ ), sugerindo que a variabilidade do NNP foi independente da variabilidade das bases nitrogenadas voláteis. 


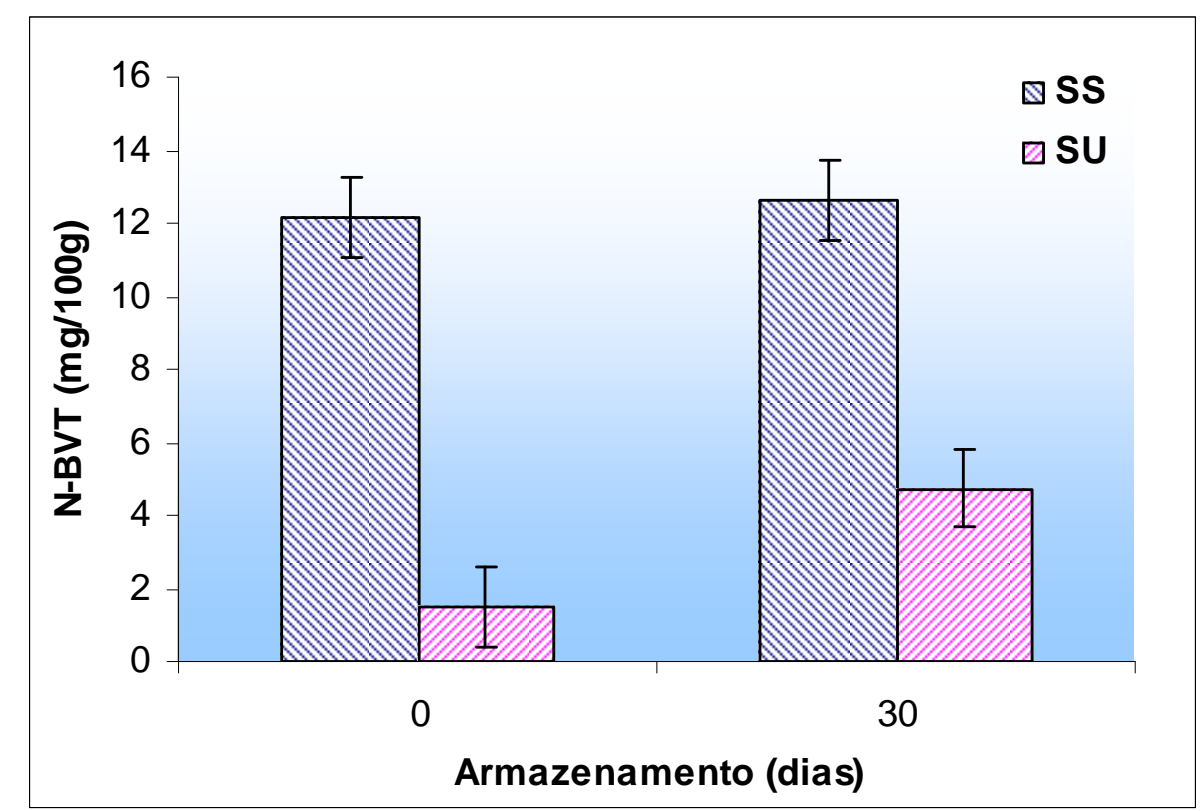

Figura 20 - Valores médios de bases nitrogenadas voláteis (N-BVT) e erro padrão dos filés de piracanjuba submetidos à salga seca (SS) e úmida (SU) durante o armazenamento.

Embora tenha ocorrido ligeiro aumento nos teores de N-BVT dos filés de piracanjuba na salga úmida, armazenados por 45 dias, estes valores ainda encontram-se dentro da faixa recomendada pela legislação brasileira (BRASIL, 2001a), tendo sido estabelecido o limite de $30 \mathrm{mgN} / 100 \mathrm{~g}$, para os peixes frescos. O mesmo comportamento foi verificado por KARAÇAM et al. (2002) que também encontraram aumento nos teores das N-BVT para anchovas salgadas armazenadas em temperatura ambiente e mantidas sob refrigeração por um período de 150 dias.

SALES et al. (1986) encontraram valores de 20,85 a 40,36 mgN/100g de BVT, para o tucunaré salgado e seco e 35 dias de armazenamento, sendo que o produto se manteve estável e com todas as características necessárias para o pescado curado. Neste estudo com a piracanjuba foram verificados dados de $\mathrm{N}$ BVT inferiores aos obtidos por SALES et al. (1986) com o tucunaré, porém muito semelhantes aos quantificados por BjøRKEVOLL et al. (2003), que obtiveram para as BVT um aumento de 6,3 para 11,7 (amostras controle) e de 6,9 para 12,3 
$\mathrm{mgN} / 100 \mathrm{~g}$ (amostras inoculadas), de 0 para 14 dias armazenamento, para 0 bacalhau (Gadus morhua) salgado e salgado-seco.

SIKORSKI (1994) relata que as bases voláteis totais são apresentadas por substâncias como amônia, trimetilamina, etilamina, monometilamina, putrescina, cadaverina e espermidina, sendo que a amônia é o composto que se encontra em maior quantidade, principalmente quando se trata de peixes de água doce.

Segundo SEO (1976), a rancidez oxidativa continua a aumentar durante o armazenamento, possivelmente em decorrência das reações do malonaldeído produzido na oxidação das gorduras com as proteínas musculares. Esse fato tem dificultado o estabelecimento de valores de TBARS claramente associado com distintos estágios de deterioração oxidativa.

Os valores médios das substâncias reativas ao ácido tiobarbitúrico (TBARS) foram de 1,72, 3,30, 1,57 e 0,88 $\mathrm{mg}$ de malonaldeído/kg para salga úmida e 2,79, $3,75,1,79$ e 1,54 mg de malonaldeído/kg para salga seca, aos 0, 15, 30 e 45 dias de armazenamento, respectivamente, podendo ser visualizados na Figura 21. $\mathrm{Na}$ análise estatística puderam ser observadas apenas diferenças significativas $(p<0,05)$ entre os dias de armazenamento e apenas uma curva de terceiro grau explicaria o comportamento da TBARS em função do tempo (Figura 21). Não foi observada diferença significativa entre os tratamentos e nem interação $(p>0,05)$ entre eles. 


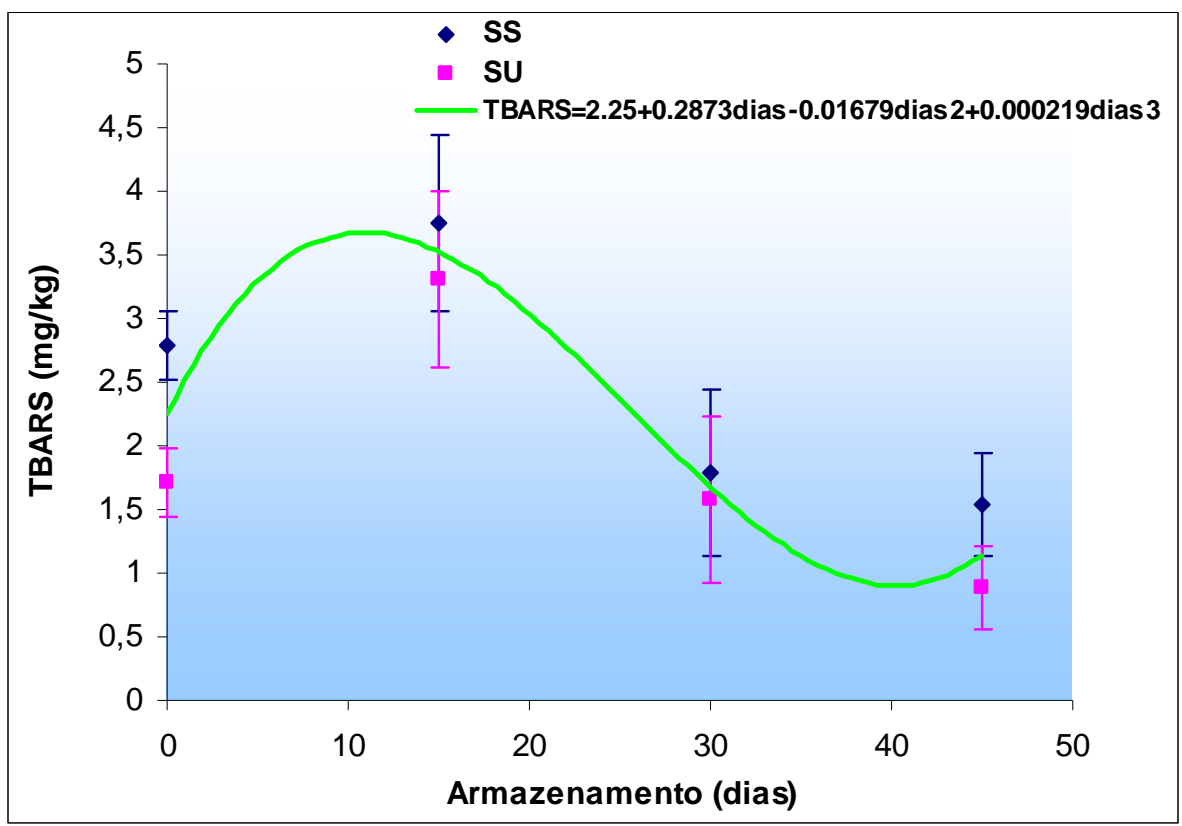

Figura 21 - Valores médios das substâncias reativas ao ácido tiobarbitúrico (TBARS) e erro padrão dos filés de piracanjuba submetidos à salga seca (SS) e úmida (SU) durante o armazenamento.

A legislação brasileira não apresenta limite máximo para $\mathrm{mg}$ de malonaldeído $/ \mathrm{kg}$ em produtos cárneos. Pode-se considerar o produto em bom estado, quando os teores de TBARS estiverem abaixo de 3,0 $\mathrm{mg}$ de malonaldeído/kg (AL-KAHTANI et al., 1996).

Segundo CONNELL (1975) o número de TBARS, entre 1,0 e 2,0 mg de malonaldeído/kg, estaria associado com o limiar de percepção do sabor de ranço, mas os valores descritos na literatura, para pescados, indicam que essa faixa seria muito baixa. No armazenamento da piracanjuba salgada e seca, todos os valores obtidos para essa variável estiveram acima desses números, porém não foram verificados sinais característicos de rancificação.

ZAPATA et al. (1986) encontraram valores entre 0,34 e 0,66 mg de malonaldeído/kg para a tilápia do Nilo salgada, seguidos de aumento desses teores variando de 3,0 a 6,0 mg de malonaldeído/kg logo após a secagem do produto.

KARAÇAM et al. (2002) observaram que houve variação nos teores de TBARS, para anchovas salgadas armazenadas em diferentes temperaturas, cujos 
valores estiveram acima de $3,0 \mathrm{mg}$ de malonaldeído $/ \mathrm{kg}$. O comportamento para essa variável, neste trabalho com os filés de piracanjuba salgado, foi semelhante ao verificado para as anchovas (150 dias de armazenamento), embora o tempo de armazenamento tenha sido apenas de 45 dias.

MACEDO-VIEGAS (2004) encontrou para os filés de tilápia do Nilo salgados e secos, 2,25 e 3,29 mg de malonaldeído/kg submetidos, respectivamente, à salga úmida e seca. Os valores observados para a piracanjuba neste estudo estão abaixo dos relatados por este autor para a tilápia do Nilo.

É importante ressaltar que concomitante às alterações provenientes da deterioração química do pescado salgado que ocorrem durante o processamento e armazenamento, alterações microbiológicas também podem estar presentes (MACHADO, 1994).

A microbiota do pescado depende em grande parte do grau de contaminação da água em que habita. A presença de microrganismos como, por exemplo, a E. coli pode ser associada à contaminação de origem fecal, sendo que o grupo coliforme é bastante utilizado para identificar a qualidade da água (VIEIRA, 2004). Desta forma, os coliformes fecais e a E. coli podem ser utilizadas na avaliação da qualidade higiênico-sanitária dos alimentos. O S.aureus tem seu principal habitat na pele, mucosas nasais e trato respiratório humano, sendo que sua presença nos alimentos, indica que o manuseio pode ter sido inadequado, equipamentos mal higienizados ou, contaminação após o processamento por fontes humanas ou de animais (VIEIRA, 2004).

A presença de Salmonella em alimentos é motivo suficiente para que o mesmo seja condenado. O habitat deste microrganismo é o trato intestinal e sua presença está associada a uma provável contaminação por fontes humanas ou de animais. Essa bactéria dificilmente prolifera em alimentos contendo outros microrganismos (LEITÃO, 1977). Quanto ao Clostridium botulinum, é o principal responsável por infecções gastrointestinais e tem seu potencial patogênico relacionado à produção de uma neurotoxina (FRANCO \& LANDGRAF, 2003).

Os resultados obtidos para a atividade de água $\left(A_{a}\right)$ e análise microbiológica para os filés de piracanjuba, peixe fresco e submetidos à salga 
úmida e seca, durante o armazenamento ( $0,15,30$ e 45 dias), estão dispostos na Tabela 8.

Observa-se na análise estatística da variável $A_{a}$, diferença entre os valores médios dos dias de armazenamento e interação significativa $(p<0,05)$ entre dias e tratamento. No estudo comparativo entre os valores médios dos tratamentos e em cada período de armazenamento, pode ser observado (Tabela 8) que de maneira geral, os valores médios da salga úmida foram superiores aos da salga seca nos períodos de 0,15 e 30 dias.

A $A_{a}$ para o peixe fresco foi de 0,99 , valor este considerado normal para a $A_{a}$ do músculo da piracanjuba "in natura", porém muitos microrganismos podem se desenvolver nesta $A_{a}$. Não foi necessário realizar a análise de bactérias halofílicas para o peixe fresco. Foram obtidos para as análises microbiológicas de clostrídio sulfito redutor, coliformes totais e fecais $177 \mathrm{UFC} / \mathrm{g}, 0$ a 0,91 NMP/g e 0 a 0,91 $\mathrm{NMP} / \mathrm{g}$, nessa ordem; porém, não foram encontradas Staphylococcus aureus e Salmonella sp para o peixe fresco.

Os valores obtidos para as bactérias do gênero Clostridium e coliformes totais e fecais, para o peixe fresco, estão adequados, de acordo com a legislação brasileira (BRASIL, 2001b). Para o pescado salgado e/ou seco não se tem registro do limite permitido pela referida legislação, para a presença das halofílicas, sendo que para as demais análises microbiológicas realizadas, preconiza-se a contagem máxima padrão de $10^{6} / \mathrm{g}$; máximo de $5 \times 10^{2} / \mathrm{g}$ para Clostrídios sulfitos redutores (a $46^{\circ} \mathrm{C}$ ); máximo de $10^{3} \mathrm{~g}$ para Staphylococcus aureus; Salmonella, ausência em $25 \mathrm{~g}$ e máximo de $10^{2} / \mathrm{g}$ para Coliformes fecais (BRASIL, 2001b).

LEITÃO (1995) relata que os diferentes grupos de microrganismos apresentam um comportamento muito diverso em relação à $A_{a}$ ótima e mínima para o seu desenvolvimento. As bactérias são as mais exigentes e poucas evidenciam seu desenvolvimento em meios com $A_{a}<0,90$. VARGA et al. (1979) citam valores limitantes de $A_{a}=0,70$ para o desenvolvimento das bactérias halófilas e bolores deterioradores do pescado salgado. No presente trabalho, os teores de $A_{a}$ se mantiveram próximos do referido valor para os tratamentos estudados. LESSI (1995) verificou que a E.coli não resiste a concentrações 
salinas de $6,5 \%$ e $A_{a}$ de 0,96 , solução saturada, ou em meios que tenham $A_{a}$ de 0,75 .

No decorrer do armazenamento os valores para a $A_{a}$ estiveram compreendidos entre 0,72 e 0,75 para os dois tratamentos, nos diferentes tempos. Estes dados estão de acordo com a literatura. LABUZA (1972) relata que os pescados salgados e secos são alimentos denominados de umidade intermediária cuja atividade de água está compreendida entre 0,60 e 0,85. Pôde-se constatar que o teor de cloreto de sal presente nos filés de piracanjuba foi capaz de reduzir a $A_{a}$ do músculo para valores $<0,97$ (Tabela 7). Valores de $A_{a}<0,85$ asseguram a estabilidade do produto, quando em temperatura ambiente.

Neste trabalho, foram encontrados valores $<1,0 \times 10 \mathrm{UFC} / \mathrm{g}$ para as análises das bactérias halófilas, nos tempos 0 e 30 dias do armazenamento para os dois tratamentos. No início do armazenamento ( 0 dias), foi detectada a presença de $S$. aureus ( $28 \times 10 \mathrm{UFC} / \mathrm{g}$ ) apenas para a salga úmida, e decorridos os 30 dias de estocagem foi verificada a ausência de colônias de estafilococos provavelmente devido a ação da salga.

Segundo MACHADO (1994) o S. aureus é o microrganismo patogênico que mais apresenta tolerância a concentrações altas de sal. OETTERER et al. (2003) citam que a bactéria pode resistir em meios contendo de 0 a $20 \%$ de sal, porém, TATINI (1973) relata que a produção de toxina pode ser inibida em valores acima de $10 \%$ e, que o valor de $A_{a}$ de 0,86 é considerado limitante para seu crescimento.

As bactérias halófilas além de crescerem em meio com elevado teor de sal promovem a deterioração do pescado salgado. Neste trabalho, a $A_{a}$ esteve abaixo desse valor, provavelmente um dos motivos pelo qual esse microrganismo não se desenvolveu. Porém, ZAPATA et al. (1986), trabalhando com salga rápida e secagem de tilápia do Nilo, verificaram que o nível de bactérias halófilicas no início do armazenamento era de $10^{3}$ a $10^{4}$, diminuindo para $10^{2}$ a $10^{3} \mathrm{cel} / \mathrm{g}$, para os primeiros 15 a 30 dias de estocagem, porém, aumentando até o final dos 90 dias de armazenamento, para $10^{3}$ a $10^{4} \mathrm{cel} / \mathrm{g}$. Esse autor considerou alto o valor obtido para os microrganismos halofílicos. Neste estudo o processo de salga promoveu 
uma completa inibição de coliformes, clostrídios sulfito redutores e de $S$. aureus. Não foi encontrada a presença de Salmonella.

SALES et al. (1986) estudaram a salga e secagem do tucunaré (Cichla ocellaris) e verificaram a presença de halofílicas, cujos teores variaram de $1,5 . x$ $10^{4}$ a $6,0 \times 10^{5} \mathrm{cel} / \mathrm{g}$, atribuindo esse alto valor à qualidade do sal empregado. Para o $S$. aureus, os valores decresceram de $1,6 \times 10^{2} \mathrm{cel} / \mathrm{g}$ para zero; coliformes fecais e totais, de $9,5 \times 10^{5} \mathrm{cel} / \mathrm{g}$ para zero, e não foi detectada a presença de Samonella. Os autores observaram que para coliformes fecais e totais os valores não atendiam às normas estabelecidos pela legislação brasileira.

KARAÇAM et al. (2002) verificaram a presença de bactérias halofílicas em anchovas salgadas sendo que os maiores teores, que variaram de 4,47 a 6,50 log UFC/g, foram obtidos com a concentração de sal de 14\% e armazenadas em temperatura ambiente $\left(22 \pm 2^{\circ} \mathrm{C}\right)$. Neste estudo, foi verificada a presença de bactérias halofílicas, para os tempos 0 e 30 dias de armazenamento, porém estes valores foram inferiores ( $<1,0 \times 10 \mathrm{UFC} / \mathrm{g})$ aos obtidos pelos referidos autores.

Os dados de microrganismos verificados para a salga dos filés de piracanjuba diferentemente dos obtidos pelos autores acima atendem às especificações (BRASIL, 2001b). A diminuição das colônias de bactérias no pescado salgado, de maneira geral, pode estar relacionada à menor disponibilidade de nutrientes, aumento na acidez com conseqüente redução no pH e competição com microrganismos halofílicos. Ainda, a provável presença de substâncias desfavoráveis à sobrevivência de bactérias do grupo coliformes pode ter ocorrido durante o armazenamento. 
Tabela 8 - Valores médios da atividade de água $\left(A_{a}\right)$ e análises microbiológicas de filés de piracanjuba submetidos à salga úmida (SU) e salga seca (SS) durante o armazenamento.

\begin{tabular}{|c|c|c|c|c|c|c|c|c|c|}
\hline & & \multicolumn{2}{|c|}{$A_{a}$} & \multirow{2}{*}{$\begin{array}{c}\text { Bactérias } \\
\text { Halofílicas }\end{array}$} & \multirow{2}{*}{$\begin{array}{c}\begin{array}{c}\text { Clostrídio } \\
\text { Sulfito } \\
\text { Redutor }\end{array} \\
(\text { UFC/g) }\end{array}$} & \multirow{2}{*}{$\begin{array}{c}\begin{array}{c}\text { Staphylococcus } \\
\text { aureus }\end{array} \\
{\text { (UFC/g })^{1}}^{1}\end{array}$} & \multirow{2}{*}{$\begin{array}{c}\begin{array}{c}\text { Salmonella } \\
\text { sp }\end{array} \\
(\mathrm{UFC} / \mathrm{g})^{1}\end{array}$} & \multirow{2}{*}{$\begin{array}{l}\text { Coliformes } \\
\text { Totais } \\
(\mathrm{NMP} / \mathrm{g})^{2}\end{array}$} & \multirow{2}{*}{$\begin{array}{c}\text { Coliformes } \\
\text { Fecais } \\
(\mathrm{NMP} / g)^{2}\end{array}$} \\
\hline & & Média* & ep** & & & & & & \\
\hline Peixe fr & co & 0,99 & 0,01 & - & 177 & ausente & ausente & 0 a 0,91 & 0 a 0,91 \\
\hline \multicolumn{10}{|l|}{$\mathrm{Arm}^{3}$} \\
\hline \multirow{2}{*}{0 dias } & su & $0,75^{\mathrm{a}}$ & 0,01 & $<1,0 \times 10$ & ausente & $28 \times 10$ & ausente & ausente & ausente \\
\hline & ss & $0,74^{b}$ & 0,01 & $<1,0 \times 10$ & ausente & ausente & ausente & ausente & ausente \\
\hline \multirow{2}{*}{15 dias } & SU & $0,75^{\mathrm{a}}$ & 0,01 & - & - & - & - & - & - \\
\hline & ss & $0,73^{\mathrm{b}}$ & 0,01 & - & - & - & - & - & - \\
\hline \multirow{2}{*}{30 dias } & su & $0,75^{\mathrm{a}}$ & 0,01 & $<1,0 \times 10$ & ausente & ausente & ausente & ausente & ausente \\
\hline & ss & $0,72^{b}$ & 0,01 & $<1,0 \times 10$ & ausente & ausente & ausente & ausente & ausente \\
\hline \multirow{2}{*}{45 dias } & SU & $0,69^{a}$ & 0,01 & - & - & - & - & - & - \\
\hline & sS & $0,71^{a}$ & 0,01 & - & - & - & - & - & - \\
\hline
\end{tabular}

*Médias na mesma coluna, por dia de armazenamento, seguidas por letras diferentes, diferem entre si pelo teste t-Student ( $<<0,05)$; ${ }^{* \star}$ erro padrão ${ }^{1}$ Unidade Formadora de Colônia por grama; ${ }^{2}$ Número Mais Provável por grama; ${ }^{3}$ Armazenamento. 


\subsection{Rendimento}

Os valores médios e erro padrão do peso dos filés de piracanjuba submetidos à salga seca e úmida, durante o processamento, estão apresentados na Figura 22. A análise estatística para o peso dos filés de piracanjuba indicou diferença significativa $(p<0,05)$ entre os tratamentos apenas para o tempo de 168 horas após o início da salga.

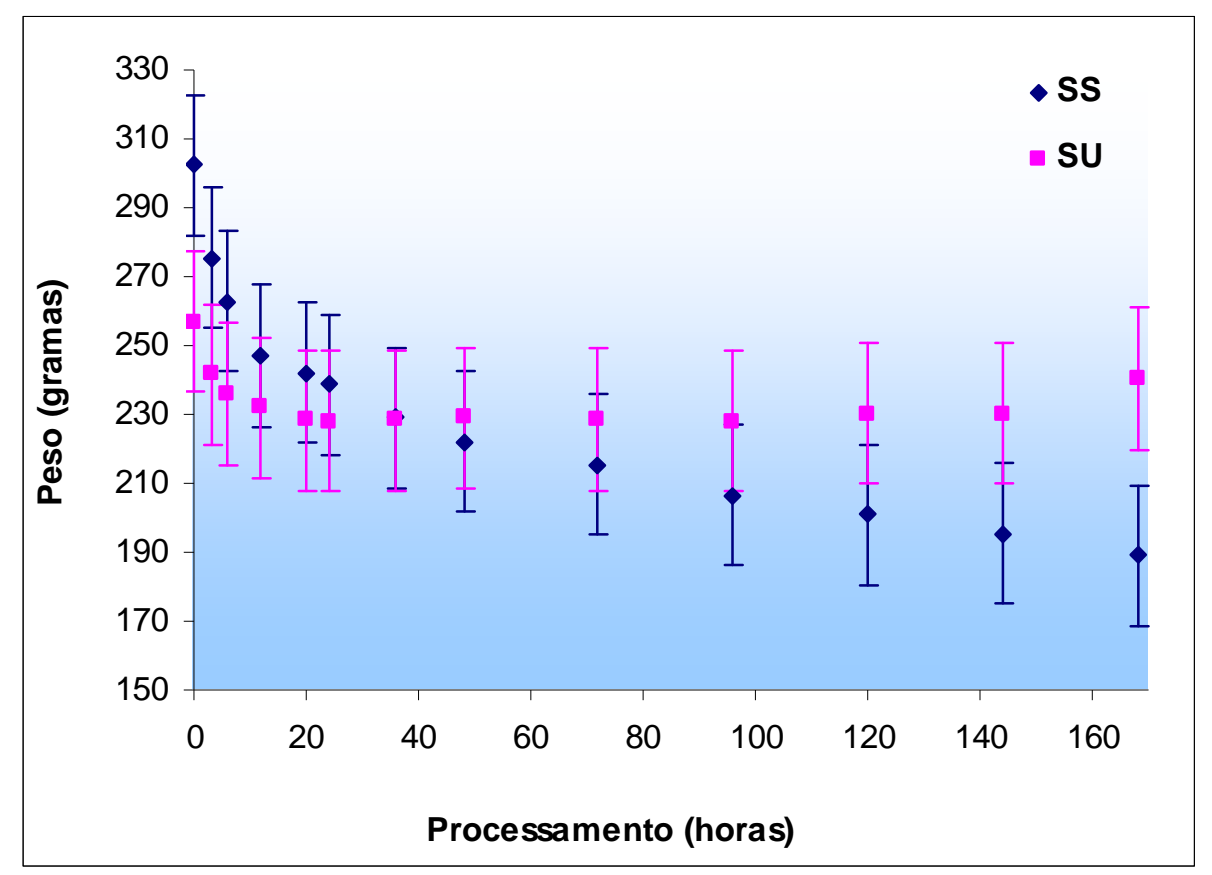

Figura 22 - Valores médios do peso (g) e erro padrão dos filés de piracanjuba para a salga seca (SS) e úmida (SU) durante o processamento.

Neste experimento (Figura 22), foi observado o comportamento descrito por OGAWA \& MAIA (1999), para ambos os tratamentos. Estes autores relatam que, na salga seca há uma redução de peso do produto, sendo que esta redução pode atingir até $30 \mathrm{~g}$ por $100 \mathrm{~g}$ do produto em relação ao peso inicial e um conteúdo de umidade de 55 a $60 \%$, porém a concentração do sal é um fator importante para estes parâmetros. Para a salga úmida há variação de peso, sendo que em concentrações inferiores a $9 \%$ de sal, o peso do produto aumenta e para 
concentrações de 18 a $25 \%$ o peso no início reduz, aumentando em seguida, devido à penetração de sal e aumento/redução de umidade na carne.

A análise estatística permitiu a observação de diferença significativa $(p<0,05)$ entre os valores médios de rendimento entre os tratamentos (salga seca e úmida), apenas no processamento, sendo de $93,62 \%$ e de $62,46 \%$, respectivamente, para as salgas úmida e seca. Porém, pode-se ainda verificar que houve uma diminuição destes rendimentos, para os dois tratamentos, da etapa de processamento para a de armazenamento. O rendimento do produto final dos filés de piracanjuba salgada e seca, no decorrer do armazenamento (45 dias), atingiu valores de $43,28 \%$ para a salga úmida e de $45,78 \%$ para a seca (Tabela 9 ). Estes valores podem ser explicados pela excessiva perda de umidade dos filés durante o armazenamento (Tabela 7) para os dois tipos de salga.

Vale ressaltar que neste estudo, os filés de piracanjuba não passaram pelo procedimento de prensagem após as 168 horas de salga, pois já estavam bastante secos. Porém, foram levados à estufa $\left(55^{\circ} \mathrm{C}\right)$, por 48 horas, e a partir desta etapa, que foi considerada o tempo zero do armazenamento, houve uma maior perda de peso para a salga úmida, estando ao redor de $30 \%$. 
Tabela 9 - Valores médios do peso (g) e rendimento (\%) dos filés de piracanjuba para a salga seca (SS) e úmida (SU) durante o processamento e o armazenamento.

\begin{tabular}{ccccc}
\hline \multicolumn{4}{c}{ Peso (g) } & \multicolumn{2}{c}{ Rendimento (\%) } \\
\hline SU & SS & SU & SS \\
\hline \multicolumn{1}{c}{ Processamento (horas) } & & - \\
\hline 168 & 256,74 & 302,44 & - & 62,46 \\
\hline Armazenamento (dias) & & & \\
\hline 0 & 163,39 & 186,16 & 63,64 & 61,55 \\
15 & 143,53 & 152,10 & 55,90 & 50,29 \\
30 & 131,43 & 159,57 & 51,19 & 43,46 \\
45 & 111,11 & 138,46 & 43,28 & 45,78 \\
\hline
\end{tabular}

O período de armazenamento, empregado em muitas operações de processamento de alimentos, pode ser considerado como um passo importante no seu preparo, diminuindo seu conteúdo de água e acentuando e/ou melhorando seu sabor. Essa etapa pode afetar, consideravelmente, a qualidade do produto final de pescados salgados e secos dependendo do método de salga empregado (THORARINSDOTTIR et al., 2004). No presente experimento, foi verificado que os produtos finais apresentaram características diferentes para os filés de pescado salgados e secos pelos métodos de salga seca e em salmoura saturada, embora os dois tipos de processamento tenham proporcionado a obtenção de produtos estáveis. 


\section{CONCLUSÕES}

Pode-se concluir que:

- a adição de sal no músculo da piracanjuba diminuiu a estabilidade térmica de suas proteínas miofibrilares, provocando redução das temperaturas de desnaturação da miosina e da actina, para ambas as salgas, sendo que a salga seca apresentou uma ação deletéria maior que a úmida;

- os filés de piracanjuba salgados e secos apresentaram, para a salga úmida, rendimento superior ao da seca, após 168 horas de salga; porém, ao final do armazenamento (45 dias), as duas salgas apresentaram rendimentos bem semelhantes;

- os processos de salga empregados nos filés de piracanjuba geraram produtos de características diferentes, porém as alterações observadas não influíram na estabilidade do produto final, que foi considerado próprio para o consumo.

A piracanjuba apresenta um grande potencial de produção e, desta forma, espera-se que seu consumo seja aumentado nos próximos anos. O processo de salga mostrou ser um excelente método de conservação do pescado e deveria ser incentivado em nosso país. Portanto, acredita-se que novos estudos devam ser conduzidos para que mais informações sobre o processamento dessa espécie piscícola sejam adquiridas. 


\section{REFERÊNCIAS}

AL-KAHTANI, H.A. et al. Chemical changes after irradiation and post-irradiation storage in tilapia and Spanish mackerel. Journal of Food Science, v.61, n.4, p.729-733, 1996.

ALM, F. Scandinavian anchovies and herring tidbits. In: BORGSTRON, G. Fish as food. New York: Academic Press, 1965. v.3, p.195-217.

ALOR, F.A.R. Controle de qualidade físico, químico e microbiológico do pescado salgado e defumado. In: SEMINÁRIO E WORKSHOP: "TECNOLOGIA DE SALGA E DEFUMAÇÃO DE PESCADO”, 1994, Guarujá/SP. Anais..., Guarujá/SP, 1994, p.56-62.

ANDRÉS, A.; RODRIGUEZ-BARONA, S.; BARAT, J.M.; FITO, P. Note: MasS transfer kinetics during cod salting operation. Food Science Technology International, v.8, n.5, p.309-314, 2002.

Anônimo. Bacalhau - identidade foi só o primeiro problema. Pro Teste, Rio de Janeiro, n.32, p.8-13, dez. 2004.

ASSOCIATION OF OFFICIAL ANALYTICAL CHEMISTS. Official methods of analysis. 16. ed. Arlington: AOAC, 1995. 2v.

AZEVEDO, P. Principais peixes das águas interiores de São Paulo, hábitos de vida. In: Poluição e Piscicultura. São Paulo: CIBPU - Faculdade de Saúde Pública da USP. Instituto de Pesca, 1972, 216p. 
BEDORE, A.G. Características e criopreservação do sêmen de Pacuaranha, Piracatus mesopotamicus e de Piracanjuba, Brycon orbignyanus. 1999. 53p. Dissertação (Mestrado em Biologia Celular) - Universidade Federal de Minas Gerais, 1999.

BERAQUET, N.J.; IADEROZA, M.; JARDIM, D.C.P.; LINDO, M.M.K. Comparação entre os processos de salga úmida e salga seca em relação à absorção de sal e alterações de qualidade. Coletânea do Instituto de Tecnologia de Alimentos, v.13, p.175-198, 1983.

BERAQUET, N.J.; LINDO, M.M.K. Transformações bioquímicas "post mortem" em pescado. Boletim do Instituto de Tecnologia de Alimentos, v.22, n.2, p.169192, 1985.

BJØRKEVOLL, I.; OLSEN, R.L.; SKJERDAL, O.T. Origin and spoilage potential of the microbiota dominating genus Psychrobacter in sterile rehydrated salt-cured and dried salt-cured cod (Gadus morhua). International Journal of Food Microbiology, v.84, p.175-187, 2003.

BOERI, R.L.; MOSCHIAR, S.M.; LUPIN, H.M. Estúdio comparativo de los processos de salado humedo e seco de merluza (Merluccius hubbsi). Revista Agroquímica de Tecnologia Alimentar, v.22 , p.139-145, 1982.

BRADFORD, M. A rapid and sensitive method for the quantitation of microgram quantities of protein utilizing the principle of protein-dye binding. Analytical Biochemistry, v.72, p.248-254, 1976.

BRASIL. Ministério da Agricultura, Pecuária e Abastecimento. Legislação de Pescado e Derivados, Brasília, 1997. Portaria n.185, de 13 de maio de 1997 Diário Oficial da União 19 de maio de 1997. 
BRASIL. Ministério da Agricultura, Pecuária e Abastecimento. Regulamento da inspeção industrial e sanitária de produtos de origem animal - RIISPOA. Pescados e derivados, C.7, seção 1. Brasília, 2001a. http://www.agricultura.gov.br/sda

BRASIL. Ministério da Saúde. ANVISA, Agência Nacional de Vigilância Sanitária, Brasília, 2001. Resolução RDC n. 12, de 02 de janeiro de 2001 - Diário Oficial da União 10 de janeiro de 2001b, seção 1.

BURGESS, G.H.O.; CUTTING, C.L.; LOVERN, J.A.; WATTERMAN, J.J. Salt curing. In: BURGESS, G.H.O.; CUTTING, C.L.; LOVERN, J.A.; WATTERMAN, J.J (eds) Fish handling \& processing. New Yor: Chemical Publishing Company, INC., 1967. cap. 5, p.102-119.

CASTAGNOLLI, N. Criação de peixes de água doce. Jaboticabal: Universidade Estadual Paulista, 1992. 189p.

CHEFTEL, J.C.; CUQ, J. Aminoacidos, peptidos y proteinas. Quimica de los alimentos. Zaragoza, p.275-412, 1984.

CONNELL, J.J. Control of fish quality. Fishing News Books. 1975. In: BERAQUET, N.J.; LINDO, M.M.K. Transformações bioquímicas "post mortem" em pescado. Boletim do Instituto de Tecnologia de Alimentos, v.22, n.2, p.169-192, 1985.

CONTE, L.; BOZANO, G.L.N.; FERRAZ DE LIMA, J.A. Influência do sistema de alimentação no crescimento da piracanjuba, Brycon orbignyanus, em gaiolas. Boletim Técnico do CEPTA, v.8, p.49-59, 1995.

CONTRERAS-GUZMÁN, E.S. Bioquímica de pescado e derivados. Jaboticabal: FUNEP, 1994. 409p. 
CONTRERAS-GUZMÁN, E.S. Bioquímica de pescados e invertebrados. Jaboticabal: FUNEP, 2002. 309p.

DEL VALLE, F.R.; NICKERSON, J.T.R. Studies on salting and drying fish. I. Equilibrium considerations in salting. Journal of Food Science, v.32, p.173-179, 1967a.

DEL VALLE, F.R.; NICKERSON, J.T.R. Studies on salting and drying fish. II. Dynamic aspects of the salting of fish. Journal of Food Science, v.32, p. 218-224, 1967b.

DEL VALLE, F.R.; NICKERSON, J.T.R. Salting and drying fish. III. Diffusion of water. Journal of Food Science, v.33, p. 499-503, 1968.

DENG, J.C. Effect of iced storage on free fatty acid production and lipid oxidation in mullet muscle. J. Fd. Sci., v.43, p.337, 1978.

DOWNES, F.P.; ITO, K. Compendium of methods for microbiological examination of foods. 4 ed. Washington: American Public Health Association, 2001.

DUMONT-NETO, R.; PELLI, A.; FREITAS, J.L.; COSTA, C.L.; FREITAS, A.E.; BARBOSA, N.D.C. Reprodução induzida da piracanjuba (Brycon orbygnianus, VALENCIENNES, 1903), durante a primeira maturação sexual, cultivada em cativeiro na estação de pesquisa e desenvolvimento ambiental de Volta Grande CEMIG. Boletim do Instituto de Pesca, v.24 (n.especial), p.105-107, 1997.

DYER, W.J.; HILTZ, D.F.; HAYES, E.R.; MUNRO, V.G. Retail frozen fishery products-proximate and mineral composition of the edible portion. Journal Institute Canadian Science Technology Alimentaire, v.10, n.3, p.185-190, 1977. 
FAO - Food and Agriculture Organization. El estado mundial de la pesca y la acuicultura (SOFIA). 2004. http://www.fao.org/documents (10/06/2005).

FARBER, L. Freshness Tests. In: BORGSTROM, G. (ed.). Fish as Food. New York: Academic Press, 1965, v. IV.

FERREIRA, S.O., OETTERER, M. Agroindústria de pescado: salga, defumação e anchovagem. Informativo Técnico n06 - ESALQ, Piracicaba, 24p., 1992.

FISKE, C.M., SUBBAROW, Y. The colorimetric determination of phosphorus. J.

Biol. Chem., v. 66, n.2, p.375-400, 1925.

FRANCO, B.D.G.M.; LANDGRAF, M. Microbiologia dos Alimentos.

Atheneu:São Paulo, 2003. 182p.

FUJIMURA, C.Q., AMAYA-FARFAN, J. e CONTRERAS-GUZMÁN, E.

Preservação da corvina (Micropogon $\mathrm{sp}$ ) por salga e secagem rápida e seu balanceamento com arroz. Boletim da Sociedade Brasileira de Ciência e Tecnologia de Alimentos, Campinas, v.16, n.2, p.111-126, 1982.

FURUKAWA, V.A.; SOBRAL, P.J.A.; HABITANTE, A.M.Q.; GOMES, J.D.F. Análise térmica da carne de coelhos. Ciência e Tecnologia de Alimentos, v.24, n.2, p.265-269, 2004.

GAVA, A.J. Princípios de tecnologia de alimentos. São Paulo: Nobel, 1984. $284 p$.

GRAY, J.I. Measurement of lipid oxidation: A review. J. Am. Oil Chem. Soc., v.55, p. 539-546, 1978. 
GRAY, J.I.; GOMAA, E.A.; BUCLEY, D.J. Oxidative quality and shelf life of meat. Meat Science, v. 43, p. 5111-5123, 1996.

HASTINGS, R.J.; RODGER, G.W.; PARK, R.; MATTHEWS, Q.D.; ANDERSON, E.M. Differential scanning calorimetry of fish muscle: the effect of processing and species variation. Journal of Food Science, v.50, p. 503-510, 1985.

HORWITZ, W. Official Methods of Analysis of the Association of Analytical Chemists, 13. ed., Washington: A.O.A.C. 1980.

HOWGATE, P. Determination of total volatile bases. Torry Research Station. Aberdeen, TD 564, Appendix 4, 1976.

ISMAIL, M.S. Solar dryers for fish. Infofish Marketing Digest., n. 02, p.31-33, 1983.

KARAÇAM, H. \& BORAN, M. Quality changes in frozen whole and gutted anchovies during storage at $-18^{\circ} \mathrm{C}$. International Journal of Food Science and Technology, v.31, p.527-531, 1996.

KARAÇAM, H.; KUTLU, S.; KÖSE, S. Effect of salt concentrations and temperature on the quality and shelf-life of brined anchovies. International Journal of Food Science and Technology, v. 37, p.19-28, 2002.

KELLEHER, S.D.; HULTIN, H.; WILHEM, K.A. Stabillity of macherel surimi prepared under lipid stabilizing processing conditions. Journal of Food Science, v.59, n.2, p. 269-271, 1994. 
KUAYE, A.Y. Comparação dos métodos para determinação das bases nitrogenadas voláteis em pescado: parâmetros críticos e modificações. Campinas, 1982. 95p. Dissertação (Mestrado) - Faculdade de Engenharia de Alimentos e Agrícola, Universidade Estadual de Campinas, 1982.

LABUZA, T.P., Mc NAELLY, L., GALLACHER, D., HAWKES, J., HURTADO, F. Stability of intermediate moisture food. I. Lipid oxidation. Journal of Food Science, v.37, n.1, p. 154-9, 1972.

LANARA. Laboratório Nacional de Referência Animal. Métodos Analíticos Oficiais para Controle de Produtos de Origem Animal e seus Ingredientes. I. Métodos Microbiológicos - Ministério da Agricultura, do Abastecimento e da Reforma Agrária. Brasília - DF, 1993.

LEITÃO, M.F.F. Microbiologia do pescado e controle sanitário no processamento. Boletim do Instituto de Tecnologia de Alimentos, v.14, n.50, p.1-35, 1977.

LEITÃO, M.F.F. Microbiologia do pescado salgado. In: SEMINÁRIO SOBRE TECNOLOGIA DE SALGA E DEFUMAÇÃO DE PESCADO, 1995, Campinas/SP. Anais..., Campinas/SP, 1995, p.110-126.

LEMOS, A. L. S. C. Salga leve de pescados. Aqüicultura \& Pesca, v.1, n.6, p. 1620, 2004.

LESSI, E. Tecnologia do pescado. In: SEMINÁRIO SOBRE TECNOLOGIA DE SALGA E DEFUMAÇÃO DE PESCADO, 1995, Campinas/SP. Anais..., Campinas/SP, 1995, p.14-17.

LUPIN, H.M.; TRUCCO, R. Variacion en el contenido de nitrogenio basico volatile (NBV) durante el procesamiento de pescado salado y conservas. Camara Marplatense de Industriales del pescado. Bol.n.93, abril, 1977 - marzo, 1978. In: 
BERAQUET, N.J.; LINDO, M.M.K. Transformações bioquímicas "post mortem" em pescado. Boletim do Instituto de Tecnologia de Alimentos, v.22, n.2, p.169192, 1985.

MA, C.Y.; HARWALKAR, V.R. Thermal analysis of food proteins. Advances in food and nutrition research. v.35, p.317-367, 1991.

MACEDO-VIEGAS, E.M. Estudos sobre nutrição de peixes e conservação de pescados de água doce. 2004. 166p. Texto sistematizado para obtenção do título de Livre Docente - Faculdade de Zootecnia e Engenharia de Alimentos, Universidade de São Paulo, Pirassununga, 2004.

MACHADO , Z.L. Tecnologia de recursos pesqueiros: parâmetros, processos, produtos. Recife: SUDENE-DRN-Div.Recursos Pesqueiros, 1984, 277p.

MACHADO, I. Características do sal e preparo da matéria prima para a salga e defumação. In: SEMINÁRIO E WORKSHOP: "TECNOLOGIA DE SALGA E DEFUMAÇÃO DE PESCADO”, 1994, Guarujá/SP. Anais..., Guarujá/SP, 1994, p.9-12.

MANTOVANI, D.M.B.; MORGANO, M.A. Componentes minerais em peixes de água doce criados em cativeiro. In: SEMINÁRIO SOBRE TECNOLOGIA DE SALGA E DEFUMAÇÃO DE PESCADO, 1995, Campinas/SP. Anais..., Campinas/SP, 1995, p.10-13.

MARTINS, S.C.S. Efeito das condições e processamento sobre a qualidade microbiológica do peixe de água doce salgado e seco. s.d. Tese (Mestrado) Universidade Federal do Ceará, Departamento de Tecnologia de Alimentos, Fortaleza. 
MATSUNAGA, Y. Proceso de salado para um clima tropical. In: BELLO, R.A. \& LIMA DOS SANTOS, C.A. Trabajos apresentados en la Tercera Consulta de Expertos sobre Tecnología de Productos Pesqueros en la America Latina. Porlamar, Venezuela, 1994. FAO Informe de Pesca. N.538, Supl. Roma, FAO. 1996. p. 29-33.

MEDINA-VIVANCO, M.L. Desidratação osmótica em soluções ternárias, secagem e transições térmicas de filés de tilápia (Oreochromis niloticus). 2003. 211p. Tese (Doutorado) - Faculdade de Engenharia de Alimentos, Universidade Estadual de Campinas, 2003.

MENDELSOHN, J.M. Rapid techniques for salt-curing fish: a review. Journal of Food Science, v.39, p.125-127, 1974.

MONTERREY-QUINTERO, E.S.; SOBRAL,P.J.A. Preparo e caraterização de proteínas miofibrilares de tilápia do Nilo (Oreochromis niloticus) para a elaboração de biofilmes. Pesquisa Agropecuária Brasileira, v.35, n.1, p. 179-190, 2000.

MORAIS, C.; SILVEIRA, E.T.F.; FIGUEIREDO, I.B. Utilização da ictiofauna acompanhante na captura do camarão-sete-barbas na forma de produto salgado, prensado e seco. Coletânea do Instituto de Tecnologia de Alimentos, v.24, n.1, p.61-74, 1994.

MORAIS, C.; SILVEIRA, E.T.F.; FIGUEIREDO, I.B.; AVANCINI, S.R.P. Utilização da ictiofauna acompanhante do camarão-sete-barbas na forma de produto salgado, prensado e seco: características física, química e nutricional. Coletânea do Instituto de Tecnologia de Alimentos, v.25, n.1, p.47-57, 1995. 
MUJICA, P.Y.C. Vida útil do cação (Prionace glauca) armazenado sob refrigeração e otimização dos métodos microbiológicos e sensoriais de avaliação da qualidade. Campinas, 2000. 103p.Tese (Doutorado) - Faculdade de Engenharia de Alimentos, Universidade Estadual de Campinas.

NETTO, F. M. Modificações químicas, bioquímicas e sensoriais do híbrido de tilápia estocado em gelo. Campinas, 1984. Dissertação (Mestrado)- Faculdade de Engenharia de Alimentos e Agrícola, Universidade Estadual de Campinas, Campinas, 1984.

NORT, E. Coletânea de informações práticas à industria pesqueira. Rio de Janeiro: Programa de Pesquisas e Desenvolvimento Pesqueiro do Brasil, 1974. 45p. (Ser. Doc. Tec.5)

OETTERER, M.; PERUJO, S.D.; GALLO, C.R.; ARRUDA, L.F.; BORGHESI, R.; CRUZ, A.M.P. Monitoring the sardine (Sardinella brasiliensis) fermentation process to obtain anchovies. Scientia Agricola, v.60, n.3, p. 511-517, 2003.

OGAWA, M.; MAIA, E.L. Manual de Pesca. Ciência e Tecnologia do Pescado. 2.ed. São Paulo: Varela, 1999, v.1, 430p.

OLIVEIRA, A.M.B.M.; CONTE, L.; CYRINO, J.E.P. Produção de Characiformes autóctones. In: CYRINO, J.E.P.; URBINATI, E.C.; FRACALOSSI, D.M.; Castagnolli, N. Tópicos Especiais em Piscicultura de Água Doce Tropical Intensiva. Editora Tec. Art, São Paulo, 2004, cap.8, p.217 - 237.

OOIZUMI, T.; KAWASE, M.; AKAHANE, Y. Permeation of sodium chloride into fish meta and its effect on moisture content as a function of the osmotic pressure of the soaking solution. Fisheries Science, v.69, n.4, p.830-835, 2003. 
PAREDI, M.E.; TOMAS, M.C.; CRUPKIN, M.; AÑON, M.C. Thermal denaturation of Aulacomya ater ater (Molina) myofibrillar proteins: a differential scanning calorimetric study. Journal of Agricultural and Food Chemistry, v. 42, n. 4, p. 873-877, 1994.

PARK, J.W.; LANIER, T.C. Scanning calorimetric behavior of tilapia myosin and actin due to processing of muscle and protein purification. Journal of Food Science, v.54, n.1, p. 49-51, 1989.

PINHEIRO, C.R. Avaliação física, química e sensorial do pescado curado, In: SEMINÁRIO SOBRE TECNOLOGIA DE SALGA E DEFUMAÇÃO DE PESCADO, 1995, Campinas/SP. Anais..., Campinas/SP, 1995, p. 149-158.

RAVESI, E.M.; KRZYNOWEK, J. Variability of salt absorption by brine dipped fillets of cod (Gadus morhua), blackback flounder (Pseudopleuronectes americanus), and ocean perch (Sebastes marinus). Journal of Food Science, v.56, n.3, p.648652, 1991.

SABADINI, E.; HUBINGER, M.D.; SOBRAL, P.J.A.; CARVALHO Jr., B.C. Alterações da atividade de água e da cor de carne no processo de elaboração da carne salgada desidratada. Ciência e Tecnologia de Alimentos, v.21, n.1, p.1419, 2001.

SALES, R.O.; MONTEIRO, J.C.S.; MAIA,G.A.;VASCONCELOS, M.E.L.; FEITOSA, T. Estudo da melhoria do processo de salga e secagem do tucunaré, Cichla ocellaris, Bloch \& Schneider, no açude de Orós, Ceará, Brasil. Ciências Agronômicas, v.17, n.1, p.81-88, 1986. 
SANCHES, J.T., JAM, R.C. Princípios técnicos de salado y secado Del pescado. Estudios químicos de sal em el litoral. Peru: Instituto del Mar del Peru/IMARPE, 1965. (Informe, 9:37)

SANNAVEERAPPA, T.; AMMU, K.; JOSEPH, J. Protein-related changes during salting milkfish (Chanos chanos). Journal of the Science of Food and Agriculture, v.84, p.863-869, 2004.

SANTAMARIA, F.M.; ANTUNES, S.A. Coloração e rendimento do filé de piracanjuba (Brycon orbygnianus, Valenciennes, 1849), (Pisces, characidae) silvestre e criada em cativeiro. Boletim do Instituto de Pesca, v.25, n.único, p.2730, 1998/1999.

SAS Institute. SAS/STAT User's Guide, Version 6, 4 ed., v.1 e 2, Cary, North Carolina, SAS Institute Inc., 2000.

SEO, C.W. Hydrocarbon production from freeze dried meats. Journal of Food Science, v. 41, p.594-597, 1976.

SGARBIERI, V.C. Proteína em alimentos protéicos. Propriedades-degradaçãomodificações. Varela:São Paulo, 1996. 517p.

SHENDERYUK, V.I.; BYKOWSKI, P.J. Salazón y escabechado del pescado. In: SIKORSKI, Z.E. Tecnología de los productos del mar: recursos, composión nutritiva y conservación. Zaragoza: Ed. Editorial Acríbia, 1994, cap. 9, p.199-219.

SIKORSKI, Z.E. Tecnología de los productos del mar: recursos, composión nutritiva y conservación. Zaragoza: Ed. Editorial Acríbia, 1994. 330p. 
SILVA, N.; JUNQUEIRA, V.C.A.; SILVEIRA, N.F.A. Manual de métodos de análise microbiológica de alimentos. São Paulo: Varela. 2 ed. 2001. 317p.

SIU, G.M. \& DRAPPER, H.H. A survey of the malonaldehyde content of retail meats and fish. J.Fd. Sci., v.43, p.1147, 1978.

SOBRAL, P.J.A.; OCUNO, D.; SAVASTANO Jr.; H. Preparo de proteínas miofibrilares de carne e elaboração de biofilmes com dois tipos de ácidos: propriedades mecânicas. Brazilian Journal of Food Technology, v.1, p.44-52, 1998.

STANSBY, M.E. Proximate composition of fish. In: HEEN, E.; KREUZER, R. Fish nutrition. London: Fishing News Book Ltd., 1965, p. 1-59. In: CONTRERASGUZMÁN, E.S. Bioquímica de pescado e derivados. Jaboticabal: FUNEP, 1994. 409p.

TATINI, S.R. Influence of food environments on growth of Staphylococcus aureus and production of various enterotoxins. Journal of Milk Food Technology, v.36, p.559-563, 1973.

TAVARES, M. Avaliação das características organolépticas físicas e químicas de pescado curado. Análises executadas em laboratório de saúde pública. In: SEMINÁRIO SOBRE TECNOLOGIA DE SALGA E DEFUMAÇÃO DE PESCADO, 1995, Campinas/SP. Anais..., Campinas/SP, 1995, p.133-148.

THORARINSDOTTIR, K.A.; ARASON, S.; BOGASON, S.G.; KRISTBERGSSON, $K$. The effects of various salt concentrations during brine curing of cod (Gadus morhua). International Journal of Food Science and Technology, v. 39, p.7989, 2004. 
THORARINSDOTTIR, K.A.; ARASON, S.; THORKELSSON, G. The effects of light salting on physicochemical characteristics of frozen cod (Gadus morhua) fillets. Journal of Aquatic Food Product Technology, v.11, n.3/4, p. 287-301, 2002.

TORRES, E.A.F.S. Oxidação lipídica em carne. Boletim da Sociedade Brasileira de Ciência e Tecnologia de Alimentos, v.22, n.1/2, p.53-71, 1988.

VARGA, S.; SIMS, G.G.; MICHALIK, P., REGIER, L.W. Growth and control of halophilic microorganisms in salt minced fish. Journal of Food Science, v. 44, n.1, p.47-50, 1979.

VASQUES, L.H. Histologia da piracanjuba, Brycon orbignyanus (Valenciennes, 1849) (Pisces, Characidadae): tecidos fundamentais. Jaboticabal: Universidade Estadual Paulista, 1997. 79p. Dissertação (Mestrado) Universidade Estadual Paulista, 1997.

VIEIRA, R.H.S.F. Microbiologia, higiene e qualidade do pescado: teoria e prática. Varela: São Paulo, 2004. 380p.

VYNCKE, W. Direct determination of the thiobarbituric acid value in trichloroacetic extracts of fish as a measure of oxidative rancidity. Fette-Seinfen Anstrichmittel, Hamburgo, v.72, n.12, p.1084-1087, 1970.

WANG, D.; TANG, J.; CORREIA, L.R. Salt diffusivities and salt diffusion in farmed Atlantic salmon muscle as influenced by rigor mortis. Journal of Food Engineering, v.43, p.115-123, 2000.

WATABE, K. Bactéria vermelha do peixe salgado. Brasil Salinero, n. 5, p.12-3, 1980. 
WRIGHT, D.J.; LEACH, I.B.; WILDING, P. Differencial scanning calorimetric studies of muscle and its constituent proteins. Journal of Science of Food and Agriculture, v.28, p.557-564, 1977.

ZAPATA, J.F.F.; MACEDO, B.A.; MARTINS, S.C.S.; VASCONCELLOS, M.E.L. Salga rápida e secagem da tilápia do Nilo (Sarotherodon niloticus). Boletim da Sociedade Brasileira de Ciência e Tecnologia de Alimentos, v.20, n.1/2, p.1728, 1986. 